

ESEK HOPKINS 
BOOKS BY EDWARD FIELD.

Tax lists of the Town of Providence during the Administration of Sir Edmund Andros. $1086=$ 1650 .

$$
\text { *io. } 50 . \text { St, wet. }
$$

Revolutionary Defences in Rhode Island.

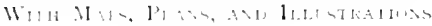

$$
\begin{aligned}
& \text { 3To. S225 net. }
\end{aligned}
$$

The Colonial Tavern: A Glimpse of New England Town Life in the seventeenth and Eighteenth Centuries.

$$
\text { (i). Sinnet. }
$$

lisek Hopkins: Commander=In=Chief of the Con= tinental Navy during the American Revolution, 1775 to 1778.

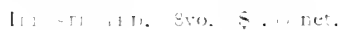




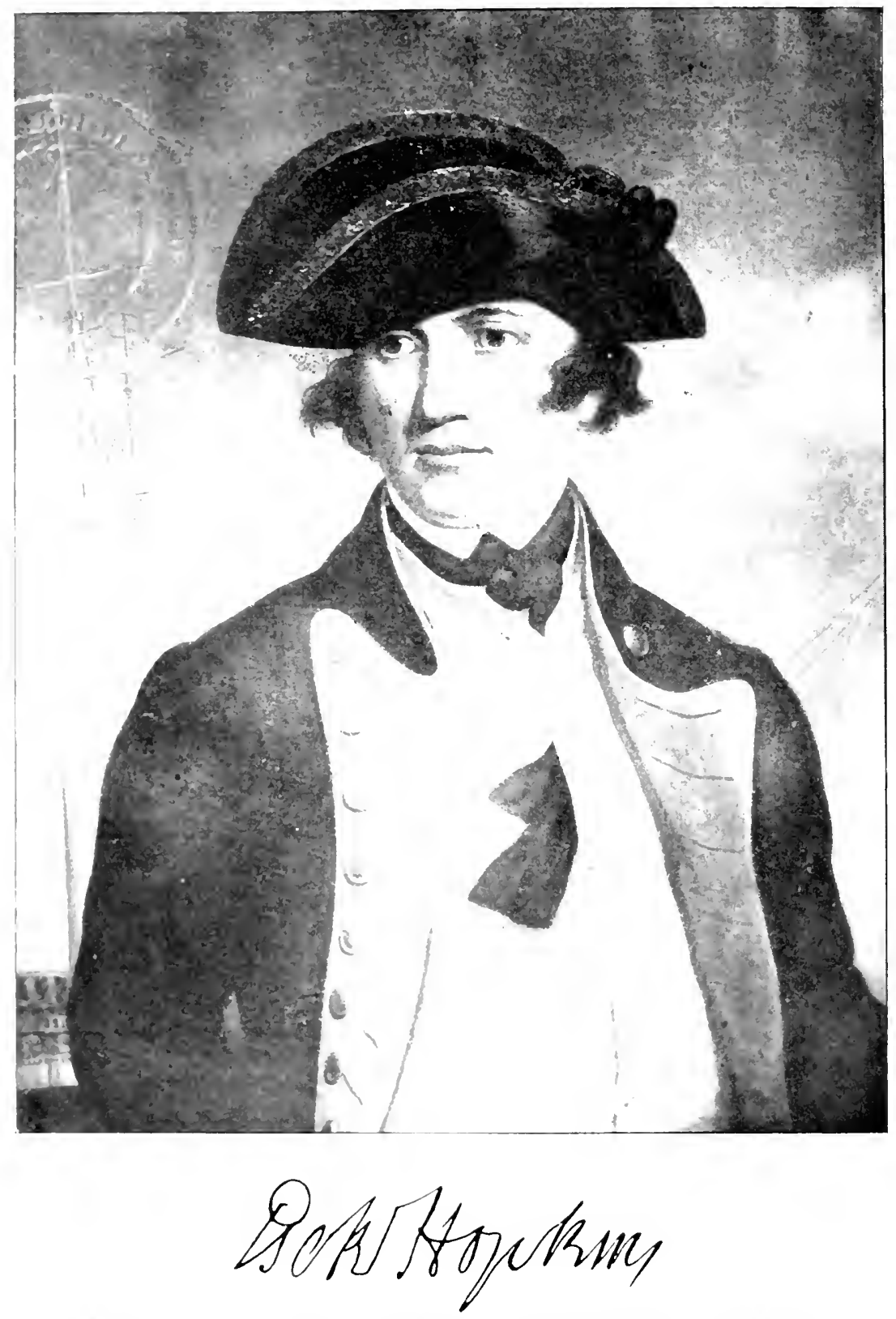


\section{ESEK IIOPKINS}

COMMANIER-IN-C IIIIE

()1

Tyle Conthental Nary

DURING THE AMLRICAN REVOLETION

$$
1775 \text { to } 1798
$$

MASTER MARINER, POLITICIAN,

BRIGADIER GENERAL, NAYAL, OFFICER AND PHHANTHROLIST

Ii)

EDWARI) FIEID A.I?.

PROIIIET⿱

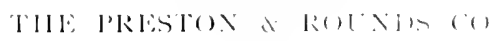

$121)^{2}$. 
Edition linited to jon copies of whinh this is No.

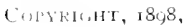

IY

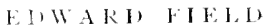

\author{
II 1 . 111

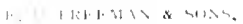 \\ IKH ITIES I, K, I.
}


TO MV IRIENI

IOKATIO ROGERS, I.I,.

JUSTIL ()F THE

SUPREME (OOURT ()F KHOIIE ISIANH 


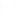




\section{INTRODUCTION}

But slender justice has been rendered to the services of Esck Hopkins in the Imerican Revolution. Historians could not omit all reference to the first Commander-in-Chief of the American Navy, but the manner in which some of them have mentioned him would seem to indicate that they wrote not from their fulness, but from their lack of knowledge concerning him. The only positive information most writers had of him, apparently, was that he had been clismissed from the naval service, and hence they inferred that he must have deserved his fate. The more satisfactory method of historical portrayal would have been to have narrated the causes that led to that treatment and let the reader draw his own conclusions as to the justice of it. 
The narrow escape of various eminent characters in our national history from supersedure or condemnation, warns us that official action is by no means a sure guide to a just judgment. The machinations of a cabal of discontented generals at one time fomented trouble for Washington in the Continental Congress, while the jealousy of Halleck, when commanding our army in the late Civil II ar, well nigh accomplished the displacement of Grant.

Whatever my own estimate of Esek: Hopkins may be, however, I have presented the facts just as I have gleaned them, that each may judge for himself what manner of man he was.

I have drawn my material entirely from official records, manuscripts and standard authorities. Of the very highest value have been the Hopkins Papers, preserved in the Rhode Island Historical Society, consisting of the official orders and letters of Hopkins while Commander-in-Chief, covering the whole period of his connection with the navy, and of a number of volumes of corre- 
spondence and other papers relating to other parts of his life.

The Hopkins Papers were deposited in the Rhode Island Historical Society, with the consent of the Hopkins hejrs. It is remarkable that so many of them have been preserved after the years of neglect which they suffered, being stored in old attics and taken from place to place and exposed for sale. Some, doubtless, have disappeared, but those remaining comprise the greater part that relate to Hopkins' naval service.

These papers are preserved in four volumes the first being the letters and orders of the Commander-in-Chief, 1776-1777; the second consists of letters and miscellaneous papers I 728-r 786 ; the third contains similar documents, $1776-1778$; the fourth is a volume of type-written copies of various papers deposited in the national archives.

These copies were made some years ago at the suggestion of Richard $s$. Howland. Esq., editor of the Providence Journal, many inquiries having been made regarding the 
official record of Hopkins service in the navy. Mr. Howland requested that a search be instituted at the several departments at Washington for all the material relating to Hopkins in possession of the national government, and that it be brought together for historical purposes. In response to this request, the departments very courteously forwarded typewritten copies of all documents bearing on the subject and they were entrusted to the Rhode Island Historical Society for safe keeping.

Besides these papers, the writings of John Adams contain much in regard to the proceedings in Congress when Hopkins was under investigation by that body, while the records of the State of Rhode Island testify to his unemitting labors in the public service for a long term of years. But it is no part of my purpose to weary the reader by here detailing all my authorities; suffice it to say that those I have mentioned form the chief.

In preparing this volume the exact language of letters, orders, and official proceeding has been preserved as far as possible, as 
it secmed to me to impart a clearer significance than when smoothed up or rumbeled out by a revising hand.

I desire to acknowledge my abligations to the Hon. Imos Perry, Librarian of the Rhode Istand Ilistorical Society, for his kindly courtesy in aiding me in procuring material, and to Mr. Fred A. Amold, of Providence, who has permitted me to use his valuable collection of old prints in making many of the illustrations for this work.

IDWARIIILI)

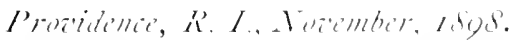





\section{CONTENTS}

CHAPTER I

ANCESTR AND EARLY LIFE . . . . . I

\section{CIAPTER II}

Mugtar Serveles axi the Begingug of The Aurricax Revolution . . . jo

CHAPTER III

Tre Organ or a Nary and the AmponeMENT OF A ComMANIER-IX-Ciner . . 63

CHAPTER IV

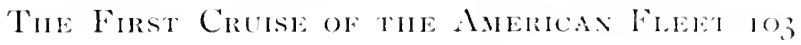
CIIAPTER V

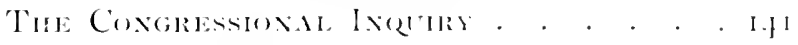

\section{CHAP'TR VI}

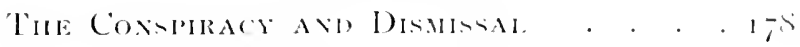

CIIATIER VII

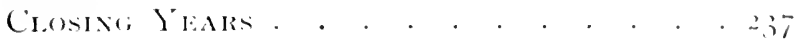


. 


\section{LIST OF ILLUSTRATIONS}

Eack Ilopkin, Pontrait Plate 6. . Funtiepiece

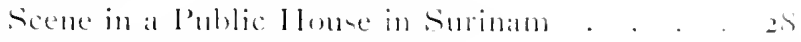
liek Ilopkins. Portrat Plate + . . . . . H Captain Abraham Whipple . . . . . . . os Captain Nicholas Biklde . . . . . . . . Sz

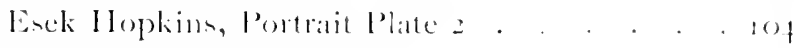
Esek IIopkins' sipy Glans. . . . . . . . I I Map of the lskand of Xew Providenee showing Operations of the Firet Anerican Naval Ex pertition

Esek IIopkins, Pontrat Plate 3 . . . . . 1,36

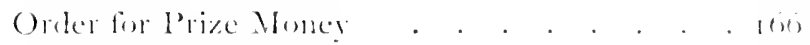

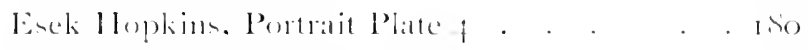
Lientenant Seth C'hapin . . . . . . . . 20) Exek Hopkine. Portatit llate 5 . . . . . . 221 Enck llopkin' sword . . . . . . . . 2.3

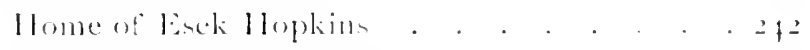

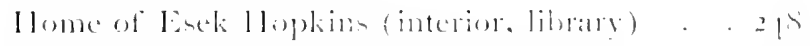

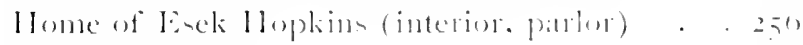
lloplins statue . . . . . . . . . 200 



\section{ESEK HOPKINS}

COMMHANER-IN-CHEE GF THE CONTHENTM NATY

\section{CHAPTER I}

ANCESTRY AND EARLY I.IFL

IARLY in the affairs of Rhode Inland, appears the name of Ilopkins. Thomas Hopkins, the ancestor of many of those in New England who now bear the name, was one of thirty-eight men who joined in an agreement for a form of government for the little settlement which Roger IVilliams cetablished at the head of Narragansett bay, and to which he gave the name Providence.

It was an unpomising settlement at first, as all new ventures are apt to be, for it was the first free govermment to be atablished in the civilized world. Enomies without it borders scoffed at the idea of a government so unstable. Enemies within its bonelers. by intrigues with the neighboring autherities. 
sought to overthrow it, yet though tauntingly" alluded to as a "nest of unclean birds" and said to be made up of those with minds too weak or too strong to assimilate with the other colonies, it wrew and flourished, and from within its limits was quarried the foundation stome on which our national fabric rests-civil liberty.

With this infant community Thomas Hopkins identified himself, and ere the settlement had seen four years of existence, was already participating actively in its affairs. Called upon by his fellow townsmen to fill. many offices of public trust, he served successirely as Commissioner, Deputy and Town Councilman. He was also for a time Town Sergeant; an ancient manuscript is yet preserved signed by Roger IVilliams, directing Sergeant Hopkins to warn certain townsmen to appear at the "Towne House" and give tentimony in a case then pending, between Thomas Angell and Robert llest. Thomas IIopkins was born in England, April 7, 1616, was the son of William and Joanna (Amold) Ifopkins, and, at his coming to Providence, was a young man twenty-four years of age.

The date of his marriage is not known, the name of his wife eren is a subject of 
conjecture, his great grandson,' who was sixteen years old at the time of his grandfatheris death, moted in his family reeord that we was a daughter of Milliam Ironolel and a sioter of Governor benedict Amold. This has senerally been admitted to be the case althoms Austin in his Cremalogical Ditionary of Rhode Ishand makes no mention of it, but another careful historical writer and genealogist ${ }^{2}$ has found that while there was nothing to absolutely disprore this theory, there was emough to create a doubt as to its accuracy. Thomas Hopkins had three soms all of whom maried and had children. Nilliam I Iopkins. the eldest son, was a surveyor, a man of learning, and held numerous town offices. It the time of King Philips Mar when the Colonial authoritics warned the people of the vatrious towns to remore to $\mathrm{Newport} \mathrm{by} \mathrm{reason}$ of its greater security frem the depredations of the savages, Milliam I Iopkins "staged and went not away," as the records quaintly note this act of heroism. I lis father, homerer, om the breaking out of the war, being well advanced in years, "with a part of his family

\footnotetext{
1 (iovernor stephen Ilopkins.

"The late Alluert Holluwok.
} 
sought an asylum abroad to escape the perils incident to the struggle," and took up his residence at Littleworth, in the Township of Oyster bay on Long Island, where he died in 1684 .

In 1699 William Hopkins was commissioned "major for the main land," which gave to him the command of the military forces of the mainland settlements in the colony. He married Abigail Dexter, the widow of Stephen I Mexter, who was a son of Reverend Gregory Dexter, pastor of the First Baptist Church in Providence, and by her had one child, a son named William. But few facts relating to him have been preserved; there is no record of the date of his birth, marriage or death, though his wife was Ruth Wilkinson, a daughter of Samuel and Plain (Wickenden) Vilkinson, her father being a son of Reverend William Wickenden, the successor of Reverend Gregory Dexter. William Hopkins junior was for a time in Providence, but he removed to what afterwards became the town of Scituate in Rhode Island, where he died some time between the eleventh of June and the ninth of October, $173^{8}$.

William and Ruth Hopkins had nine children, their names being William, Stephen, 
Rufus, John, Hope, Esek, Samuel, Abigail and Susamma, wo of their sons, Stephen and Esek, becoming conspicuous by reason of distinguished public service. Four of these sons, William, John, Samuel, and Esek followerl the sea, and all but one were masters of ressels. William, the eldest son, "was re. markable for his dash and enterprise, his career being marked by many characteristics of a resolute and reckless nature." In evidence of this there is a well established family tradition that when a young man but nineteen years of age, being in I, ondon at the time of a riot which threatened the safety of the Royal Family "he promptly oromized a force of sailors and loyal citizens, under the inspiring cry 'Fall in and protect the King', and rushing to the onset, quelled the disturbance, to the great gratification of the imperilled dignitaries." For this act of heroism he was the recipient of many royal favors. He was commissioned a colonel by King George I, but service in America being more to his liking he sold his commission and returned home. There is yet preserved among the possessions of the Rhode Island IJistorical Society a fragment of a coat which originally formed a part of a court suit presented to 
William Hopkins for his gallantry on this occasion. This suit was carefully kept by him, and after his death the desire to secure this interesting relic became so great among his numerous descendants, that it was cut into pieces, and the parts distributed among them. The piece thus preserved came into the possession of the late Stephen Randall, who married one of the descendants, and by him was presented to the society where it now remains. Another brother, Captain John Hopkins, died at sea, while yet another, Captain Samuel Hopkins, died at Hispaniola while on a voyage. The services of Stephen Hopkins to the colony of Rhode Island and to America are a part of the nation's history. Esek Hopkins, another son of William and Ruth Hopkins, was born April 26, I7 Is, within the territory now included in the town of Scituate, R. I., but then a part of the town of Providence. The neighborhood about the Hopkins homestead farm was called by the Indian name of Chopomisk, and was in the midst of a wild and sparsely settled country. His boyhood days were spent upon the farm, but upon his father's death, being then "a stout, tall and handsome young man," twenty years of age, he journeyed to Providence, where he 
obtained a berth on a ressel then about to sail for Surinam, and entered upon a seafaring life. Two of his brothers, John and Samuel, were at this time masters of vessels which no doubt influenced him in taking to the sea.

At this period the commercial activity of Rhode Island was evidenced by ships from her waters in all ports of the world. There was hardly a ressel engaged in the carrying tracle in the colonies but what numbered among its crew, or had for a master, a Rhode Islander. Born and brought up within a colony with a navigable coast line of more than two hundred miles, dotted here and there with ships loading and unloading at the wharves, or keels stretching out upon the sandy beaches, it was but natural that a spirit of adventure should have been awakened among her people for a life which offered so many opportunities for advancement and gain, as well as affording means for acquiring greater knowledge by contact with the great world outside. "It was no accident," says a learned writer, "that from a period long preceding the IVar of the Revolution, the term "Rhode Islander' had come to be synonymous with "a born sailor."

Hopkins entered upon his new life with all the spirit and zest which characterized the 
seamen of those day's. He soon rose to the command of a vessel and took a prominent rank among New England master mariners. When twenty-three years of age he married Desire Burroughs, a daughter of Ezekiel Burroughs, a leading merchant and ship master of Newport, R. I., the ceremony being performed in that town, by the Reverend Nicholas Eyres, on November 28, I74I. At this time he was living in Providence, but upon his marriage he took up his residence at Newport, from which port he sailed in command of various ships engaged in the carrying trade. About the year I 748 , Hopkins removed from Newport to Providence, and at a general town meeting held on August 30 of that year, was propounded as a freeman of the town of Providence. It does not appear however, that he took the oath of fidelity required of all freemen until January i 4 , i 750 , nearly two years later. During these years he was doubtless at sea, which precluded his appearing in open town meeting and swearing allegiance, as was the custom.

He carly became interested in the cause of education, and almost the first official duty which he performed for the town was on a committee to have the care of the "townes 
schole and of appointing a schole master." Associated with him on the committee were Nicholas Cooke, who afterwards became (ionernor of the colony, Joseph Olney, Elisha Brown, and John Mawney, and all leading men in the town affairs. The deep interest which the committee gave to the duty of hiring the school master, and the earnestness with which they regarded the matter of education, is shown in one of the articles of the indenture executed by the committee and George Taylor, who was selected to direct the young ideas in this town school for the year 1753 . for it was provided "he school or teach one poor child such as said committee shall recommend gratis or for nothing during said term." How much credit is due Ifopkins in this movement for the establishment of a town school cannot of course be determined. It is certain however, that up to this time there had been no official action taken towards the education of the youth of the town. William Turpin many years before had served as schoolmaster under some town sanction and had carried on his instructions at his tavern, but so far as any evidence is found, this wan the first school committee appointed to establish a place for instructing the children, and 
from this small beginning developed the splendid system for which this town subsequently became widely noted.

Long years after this Hopkins was called (1) grive his services in the cause of education, and for twenty years he was a trustee of Rhode sland College, now Brown University, and was highly esteemed by Manning, its distingruished president.

I) uring what is generally termed the "Old French War," from 175t to 1763 , privateering was largely engaged in by the people of New England; Rhode Island merchants especially, fitted out at great expense numerous ressels to prey upon the commerce of the enemy; so enthusiastic were the privateersmen at this period and so intent were they upon the capture of desirable prizes, that not only ships hailing from ports of France and her colonies but those hailing from other countries were attacked, captured and taken into New England. Spain especially suffered from these captures, until at last formal complaint was made, through Mons'r d'Abreu, envoy extraordinary from His Catholic Majenty, to the King, and Rhode Island was promptly rebuked for these outrages or depredations, as they were plainly called, by 
William Pitt, the Iome Secretary, in his letter to the Governor of Khode Istand.

It is during this period that most of the references to Hopkins' early maritime actventures are found, and these are nearly all connected with the year 1757 . That he commanded a privateer and was eminently suecessful in his cruises seems certain. Moses Brown of Providence, afterwards a leading merchant, wrote on February 23, $175 \%$, "Capt. Esek Hopkins has Taken and sent in here a snow of about 5 o tons, Laden with wine, oil, l)ry goods \&e to ye amount of about f6000 ye greater part of which will be Exposed to publick Vendue ye Tuesday next."

On the fifteenth of September John Brown of Providence, a brother of Moses Brown, and later his business partner, writing from Philadelphia says, "by a man from New Providence have heard that Capt Esek Hopkins \& C $\mathrm{Ch}$. Waterman put in there about the middle of Aug Last to Cleane there Vessel \& that they both saled on there Cruse about the zoth of Augst but had Taken nothing before. but what have heard of." Among the private papers left by Hopkins is an "acet sales of Sundry prize goods sold at Vendue taken by Capt Esek Hopkins and condemned in the 
Court of Vice Admiralty of Connecticut." It is dated at New London, November, I 757 , and certainly indicates that the days succeeding the 2oth of August were not spent unprofitably. From these it would seem that he was identified with ressels belonging to the Browns. It was during the year previous to these privateering ventures that Hopkins established himself on a farm consisting with subsequent purchases of more than two hundred acres, situated in the northern part of the town. He had doubtless accumulated a substantial store of this world's goods from his royages and from mercantile pursuits, for he is called in deeds both mariner and shop keeper, and was thus able to establish a comfortable home for his family which at the time of this purchase, June 26,1756 , consisted of his wife and six children, the youngest a daughter not yet two months old.

He did not however remain ashore to pursuc the life of a farmer; the dash and excitement incident to life on board a privateer, the enticing visions of greater profit from successful royages to the Spanish main and the Indies proved more attractive than the less exciting occupation of a country gentleman and farmer. His house, while he was 
ashore, was a popular gathering place for his large circle of acquaintances and friends and he delighted in entertaining them; there were hunting trips in the wild woods, shooting at marks and other sports to occupy the time on such occasions, but with all these pleasures he found time to devote much attention to carrying on his farm, employing many negroes in this work. If he had slaves the fact has not been handed down. There is an old indenture, dated in the year 1764 , yet preserved. that testifies to his taking one Edward Abby, a free negro, one of the poor of the town, to learn the art of husbandry. He cloubtlens found the duties of farm life irksome and uninteresting, compared with the life at sea. I luring this time ashore his services had been at the disposal of his fellow men, and he filled many positions of honorand trust, being school committee-man, fire ward, tax assesion, and, in I 762 , with Moses Brown, John Smith, Benoni Pearce, Nicholas Tillinghast and benjamin Man, served as director of a lottery authorized by the (ieneral Asisembly, to raise foooo for paring the streets of Providence.

In the field of political strife lopkins took a furm stand. He was uncompromising and positive. In the election for colony officers. 
in the spring of 1,63 . Elisha Brown, "a man of great abilitr and enterprise," and a prominent politician, was a candidate for the office of Deputy Governor. John Gardner, of Newport, being the opposing candidate. Hopkins entered into the campaign with activity and acrimony. It was in the days of what has been known as the Ward-Hopkins controversy, when Samuel Ward and Stephen Hopkins, the two great leaders in the political life of the colony, were arrayed against one another, each advocating political opinions and principles which kept the freemen of the colony in a ferment of party strife. So evenly were the forces of these two great leaders matched that the elections were always close, Hopkins being the successful candiclate at one time to be succeeded by Mard the next. During the period from 1758 to 1,68 Stephen Inpkins held the office of Governor from March $1+1758$, to May, 1762 ; from Nay, 1763 , to Nay, 1,65; and from May, 1,67, to May, $1-68$; while Samuel Ward held the office during the intermediate years. It was in the midst of this ten years struggle that Esek lopkins became a prominent figure. Elisha Brown was on the ticket with Ward and the fight was bitter. In addition to this, Hopkins 
had a peronal interent in the campaign: he was one of the candidates for representative to the general assembly from the town of l'rosidence. 'The relations between Esek l Jopkinn and his brother stephen were alway most affectionate and friendly, and with the tien of brotherhood he maturally became a stronge supporter of the I lopkins ticket. Besiden thin the relations between Mr. Brown and himsedf were strained, the former having published certain offensive information "in a Boston Paper." In the midst of the contest I lopkins prepared and cansed to be published, in the columms of the l'rovidence (iastte, the following open letter:

$$
\text { "PRovintacke April 10, 1,63. }
$$

The public cammot but remember that about two Years since lisha Bromn, lisel advertised in a Boston Paper, that Mr. I Ioprkins had two Sons at the Island of I lispaniold. Masters of flages of fruce. Now this rery identical Mr. Brown, who is at this lines a Candidate for l)eputy (iovermor of the Colony, has in this great Scarcity of Provision. when one Half of the Country in almost ready to starve for llant of bread, sent one of his Sons in his large noted birig called the 
Wainscot, with about Six Hundred Barrels of Flour,and other Provisions on board, directly to Port-Louis, on the Island of Hispaniola, one of the most bare-faced Things that has ever been done in the King's Dominions; but what cannot a Man of Mr. Brown's Stamp do?

I would likewise observe, that this very Mr. Brown, in his Piece which he published before the Town Meetings ${ }^{1}$ in the year i 760 , entitled, Reflections upon the present State of affairs in this Colony; boasted, "That he had not since the first Commencement of the War, transported a single barrel of Provision, nor so much as a Firlin of Butter contrary to law"; and avers, among several other Things of the like Nature, that "the Exportation of such large Quantities of Prorision, is one principal Cause of the great Scarcity of bread in the Colony." I would refer the Public to that whole Piece, and they will soon perceive the Views he had in altering the Administration, by comparing his present Conduct with the Pretentions he there makes

ESEK IOPKINS.

N. B. The Brig Hainscot, sailed from thence about the Month of September last." 
It no doubt had its effect and contributed to the defeat of the Wrard ticket, for the spring campaign of 1763 resulted in the election of Stephen Hopkins of Providence, Governor, and John Gardner of Newport, Deputy Governor.

In his relations with his fellow men Hopkins was frank and outspoken, he made no attempt to conceal his opinion on subjects which aroused his interest or appealed to his sympathies, aggressiveness seems to have been a prominent trait of his character; it led him into controversies early in his political life, and it grew and increased in magnitude as his years advanced.

He was quick to penetrate trickery or deceit and quicker still to expose it, there was a strong individuality to his make up which sometimes operated more to his own discomfort and disadvantage than to right the supposed grievance or to elevate himself in the estimation of his fellow men. With a character strong and positive, coupled with the dictatorial manner of the master mariner of the times, he naturally made enemies and became easily drawn into controversies.

Not long after he had entered into political life this controversial tendency asserted itself; 
perhaps in these days he would be called a reformer, for, notwithstanding the bitterness of his attacks on persons and measures, his shafts were aimed at wrongs against his fellow men although it must be said that insinuations against those near and dear to him, as the charges brought by Mr. Brown against his sons, sometimes prompted him to defend if not to revenge himself. In I 753 Hopkins was a member of a committee appointed by the town to arrange for opening a town school. This committee selected George Taylor for the position of instructor, and he entered upon his cluties. Taylor, besides gaining support in this venture from the town and his pupils, receired also a salary of $f \mathrm{I}$ a year from the "Society for the Propagation of the Gospel in Foreign Parts," he being the "Society's schoolmaster;" for more than forty years he acted not only as instructor, but as spiritual advisor, to the younger element in the torn. ()n October 1\$, 1737, Mr. Taylor wrote to this sreiety "that he teaches twenty-three whites and two black children and catechises them on Wednesdays and Saturdays, explains to them the principles of religion which they have learned by heart," and the Society in its report for that rear adds "this with $\mathrm{Mr}$ 
'Taylors' good life and conversation, comes attested by I)r. McSparran." In I 776, nearly" forty years later, the Society's report says, "Mr. 'Maylor, the Society's schoolmaster, notwithstanding his advanced age, gives constant attention to his school." With the Reverend John Checkley, Reverend l)octor McSparan and the Reverend James Honeyman, all ministers of the Church of England. Taylor was on the most intimate terms, while his daughter, married the Reverend John Graves, some time "Vicar of Chaplin, in Yorkshire, in the l)iocese of Chester, a most pious and worthy clergrman," and brother to the Reverend Matthew Giaves, missionary at New London. Comn. Taylor seems to have carried on the school satisfactorily and,in addition to his dutien an pedageg, he filled the positions of justice of the peace, member of the town council. and for several years was president of that body. lle acted also as scrivener for the tomnspeople, and many ancient documents. now preserved, testify to his excellence as a penman. In I 762 Hopkins became insolved with haylor in a bitter quared. It is difficult to ascertain how it came about or the direct cause: it was started however, by l Lopkins in an open letter 
signed by him and circulated about the town, there being no newspaper printed in Providence at that date to serve as a medium between the two disputants. Only one of the letters in this controversy has come to light, and as it furnishes all the information known regarding the trouble, it is here repeated in full from the original, on file with the Hopkins papers, in the possession of the Rhode Island Historical Society.

"To the Public.

A Brief Reply to a Paper signed by George Taylor, Esq., dated April I 1 , set forth as an Answer to one of mine, dated April 2.

I Observe a great Deal of Scurrility thrown out against me, and several Gentlemen in this Town; but all the answer I shall return Mr. Taylor, in respect to myself, and of my not writing my Piece, which he insinuates, is this, That whoever exposes the evil Practices of a Miser, may expect to receire ill Treatment: And as for the Gentlemen he hints at in his Piece, no Doubt they are able to Answer for themselves. - But this much I must suppose, that Mr. Taylor has taken a Suit for a Mortgage, in the Room of a Bond, and that seems evident from the Number of 
Papers in the Case he has produced, which are Fifteen, and in a Case for a Bank liond there should be but Three, Mr. Taylor says, he drew but Thirty-two or Thirty-three of the Bills of Cost, and Mr. Jackson the Rest. as attorney to the Treasurer; but had Mr. Jackson any Thing to do with them as an Officer? for the Clerk examined, and the Judge taxed them, no Doubt more than what the Law allowed, in order to Colour their own. Now let us see what Mr. Taylor says, in Answer to my Charge against him, which was, that he as an Officer took more than double the Fees the Law allowed. Why truly he says, some other People had done wrong before him? And I answer, that every Man that has behaved ill might say the same, that there has been bad Men before them. Mr. Taylor seems to confess that he had done wrong, by being new in the Business; but all that are acquainted with him, know that he has held more Justice's Courts within Twenty Years, than all the other Justices in the County.-I would advise, that whenerer a Miser is put into an Office, that in the Room of his being sworn to observe the Laws of the Government he should be sworn to follow his own Interest. Upon the Whole, I 
think it is high Time there was a Stop put to the exorbitant Fees not only of the Judges but the Sheriffs also, who now exact as much as will satisfy their avaricious Appetites, without any Regard to the Laws they are sworn to observe.

\section{Eser Hopkins.}

Providerce, April is, i $762:$ :

Both these men emerged from this conflict without apparent injury to their character or standing in the community. Taylor lived for several years, enjoying the highest confidence of his neighbors, and was honored by being elected to offices of especial honor and trust. He died in 1778 , and by his will, executed on the eighth day of October of that year, he made his son-in-law, the Reverend John Graves, one of his executors. Graves "was the successor of the Reverend John Checkley, of St. John's Church, in Providence, and attended the service until July, 1776 . He then declined to officiate, unless he could be permitted to read the usual and ordinary prayers for the King, which he considered hinself bound by his ordination vows to offer for him. The patriotism of his hearers forbade this, and the consequence was that the 
church was closed most of the time during the war of the Revolution."

The next year, as the time for the election approached, the two partics again prepared for the struggle. There was the same intensity of feeling, the same bitterness of political strife. Stephen Hopkins and Samuel IVard were the candidates for Governor, and the Vard-Hopkins controversy the issue.

Esek Hopkins was again a canclidate for the legislature and active in the campaign. He was backed by strong and substantial men, the Brown Brothers, Nicholas, Moses and John, leading men of the town, men too whose influence was a power in the community. Hopkins had commanded their ressels, they knew his worth, they had had opportunities for a study of his character and capabilities, they believed in him and that confidence was reciprocated. With the Brown Brothers and with Joseph Brown he openly made political warfare against the secretary of the colony, Henry Ward, of Newport. He was tainted with IVard heresies and must be removed, his influence was powerful, and the freemen of the colony were warned to cast their ballots for a candidate more suitable to the Ilopkins 
faction, and Hopkins, with the Browns, sent broadcast this circular:

$$
\text { "Pkovidence, April 2, i } 764 .
$$

As the present Secretary will not be satisfied to enjoy his Office peaceably, but is constantly endeavoring, by every Means in his Power, to remove the Governor, DeputyGovernor and assistants, with whom he serves, from their Offices, it hath been thought just to set up some other Person for Secretary, who might be careful to do his Duty, and behave peaceably in his Office. And as Mr. William Richardson, a person every Way well qualified, is now Candidate for that Office, we ask it as a Favor of every Freeman to give him a vote.

Esek Hop'kins,

Nicholas Browx, Joseph Brown, JOHN BROWN, Moses Brown."

The Brown and Hopkins candidate for secretary was defeated, Governor Hopkins however was elected, as was also Esek Hopkins. Henry Ward was too firmly entrenched in his position to be affected by the influences which made and unmade other colony 
officials, and he served in his office with honor and distinction for thirty-seven years, when death closed his long and useful public life.

The Brownsand Hopkins had beenstaunch allies in this campaign, but a time was coming when the relation between these men would be strained, when all the power and influence which Hopkins possessed would be exerted against them, not on account of private motives or personal grievances, but because he believed it a duty he owed to the cause which he espoused. His action at this time shows his high patriotic character as no other act in his whole life; it disclosen an honesty of purpose, a determination to serve his country first, all else being subservient to this.

The following year Esek llopkins was again clected to the general assembly, members of the lower house being then designated as deputies, and he the fourth deputy from the town of Providence. He did not however serve the full term for which he had been elected, in the service of the colony. The attractions of the sea were more to his liking, and the profits of successful royages more alluring than the honors and excitement of political life, and on the "last tuesclay in 
August i 64 ," the day on which the Providence town meeting was in session, he came before the freemen there assembled, and stated "that he was bound in a few days out of the King's Dominions, to abide for a Long time, and that he could not represent the town any longer". His resignation was thereupon accepted, and the freemen proceeded at once to elect as his successor John Cole, Esq., the moderator of the meeting. Before Hopkins entered again into political life great events had taken place, and greater ones were in store.

In February, 1765, Captain Owen, who had arrived in Providence on the $13^{\text {th }}$ of that month from the IVest Indies, reported that "on the zoth ult., in Lat. 33 Long. 68, he spoke with Captain Campbell, in the Brig 'Gambia' of, and for New York, from the coast of Africa, who acquainted him of the safe arrival of Captain Esek Hopkins, of this Port on the Coast."

For nearly four years he continued at sea, making long voyages to Africa, China and the West Indies; occasionally during this period he is reported by vessels entering New England ports, and his own safe arrival in Rhode Island is duly chronicled in the newspapers. 
Upon returning to his native shores after his life at sea. Hopkins found that during his absence the town of North l'rovidence had been incorporated, and his homestead fell within the lines of the new town. It was not long before the people of North Providence sought his services and advice, and at the spring election of 1768 he was selected as second deputy from the new town. Before this term for which he had been elected expired, he was again on the ocean; the Providence Gozette for March 16, 1,69, reports in its marine intelligence, "Capt. Esek IIop)kins from Surinam on the 16 th ult in lat 30 , Long 62 spoke the Brig 'Rose' from Madeira for Philadelphia, out for 34 days, all well."

On the third of Nosember following Captain Aulger, who had arrived in Providence that day from Surinam after a royage of thirty-seven days, reported that he left at that place when he sailed Captains Esek, George and John Hopkins, all of P'rovidence.

It was about this time, and quite likely while on this voyage that the only life portrait of Hopkins now extant was painted. This picture in which his figure appears represents a scene in a public house at 
Surinam. It so happened that a large number of ressels hailing from Rhode Island were at this time in port, and the masters and supercargoes, taking advantage of this, made arrangements for an erening's pleasure ashore, to which a few other choice friends were invited. It is the work of an English artist by the name of Greenwood, who was of the party, and who is said to have been a noted portrait painter of that day. All the figures are likenesses of the persons who actually participated in the carousal, and were esteemed very good likenesses at the time. "Indeed" wrote the owner, Dr. Edward Wild, many years ago, "the resemblance of several of them can be clearly" traced in the features of their descendants of the present day." The artist represents himself as just passing out the cloor and vomiting. Mr. Jonas IVanton, of Newport, fat, round faced, asleep, and just being baptised; Captain Ambrose Page, vomiting into the pocket of Wanton; Captain Nicholas Cook, afterwards Governor of Rhode Island, under a broad hat, with a long pipe, seated at table talking with Captain Esek Hopkins, 


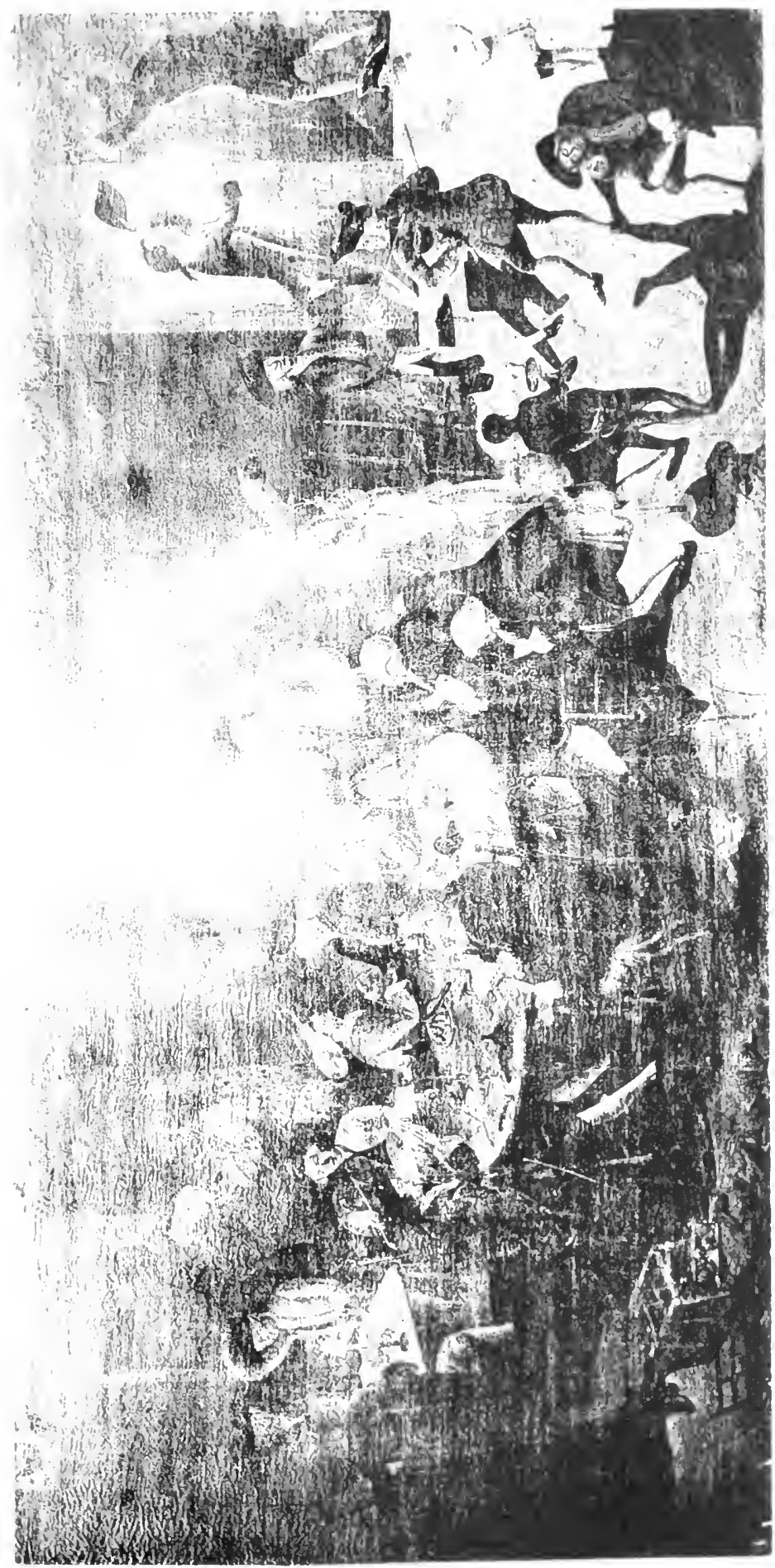


. 
wearing a cocked hat and left hand suspiciously holding a wine glass. Mr. Codfrey Malbone, of Newport, dancing, the shorter one receiving the lesson, while Captain Nicholas Power is acting as instructor; a Dutchman seated on a chest nursing his leg, doubtlens having received a kick from one of the roysterers, and several others whose features are not now identified. Several of the party, some six or eight, were members of the Jenckes family, through which family the picture has descended to its present owner, lidward J. Cushing, Esq., of North Providence. The picture came into the possession of Mrs. Mary J. Wild, whose mother was a Jenckes, soon after her marriage, in I $\$$ r 9 . It was then taken from North Providence to Brookline, and in $S_{25}$, as it had become somewhat defaced, was turned over to a man by the name of Laughton, a carriage and sign painter, of Brookline, to be repaired. His touches were of the crudest character, and before varnish. ing it he took the liberty of repainting the floor a dull yellow, thereby obliterating the date and spoiling the perspective. It was returned to North Providence to the old mansion, the home of Mr. Cushing, in I 85 s. where it now rests, and where it has been 
nearly all of the time since rsoo. It has received some injury since that time, yet it is still in good preservation. It is painted on bed ticking and is seventy-three and threequarters inches long by thirty-six and onehalf inches wide.

Besides being interesting as containing this portrait of Hopkins, it has some additional interest from containing a portrait of Hopkins' life-long friend, Captain Ambrose Page, even though he may be represented in a rather undignified position.

The year r 77 r again found Hopkins the choice of his townsmen for the legislature, and for the next three years he was returned as the first deputy from North Providence.

At this time he seems to have abandoned the sea, which he had followed for nearly thirty-five years. He had acquired a competence, and he doubtless felt that he could well afford to settle down on his farm and enjoy the companionship of his wife and family, from whom he had been separated much. He had earned a well merited reputation as a master mariner of great success,

rapt. Ambrose l'atge marriel Sarals (lenckes) IJopkins, the widow of Capt. Christopher Hophins, who was the son of Willam, lin ther of liset. 
skill and ability, and his name was a familiar one in all the ports of the maritime world.

I) uring these years momentous quentions were agitating the minds of the American Colonists.

It was a critical period in the affairs of America, "the third and final period of the constitutional revolution, the period which separated the colonies from the mother country." Already orert acts of violence against British authority had taken place in Rhode Island. July r9, i769, the revenue sloxp) "Liber.y" had been seized by a party of Newport citizens and clestroyed. In Massachusetts, the Boston riots had taken place, and these conflicts between the pepulace and the military authority showed plainly enough the temper of the colonists, and that "oppression drove wise men mad." North Carolinians had nursed their grierances until patience had become exhalleted, and, on the roth of Nay, 1771, a large number of the people, under the leadership of able and distinguished men, became involved in contliet with the governor at the head of a military force, resulting in the death of twenty of the citizens and nine of the soldiers of the King army. Following this the people of liostom had 
answered John Rowes' significant query, as to how tea and salt water would mix by a practical illustration in the waters of the harbor, while the proceedings of the house of Burgesses, of Virginia, had been the subject of argument and action by Hopkins himself, in connection with his associates in the legislature of the colony of Rhode Island.

And all these acts were like the low mutterings of the distant thunder, a warning of a coming storm.

During this period, too, had occurred that daring attack made by certain of the townsmen of Providence, on the British armed sloop "Gaspee." This exploit was instigated and carried out by a leading merchant and a party of master mariners, aided by a number of daring young men. The outrages that had been committed by the "Gaspee," commanded by Lieutenant Duddingston, had borne particularly hard upon the ressels sailing in Narragansett Bay, as he had "made it his practice to stop and board all ressels entering or learing the ports of Rhode Island, or leaving Newport for Providence." So incensed had the people of Providence become at this high handed and unwarranted action of the British officer, 
that the most heroic measures were taken to rid the bay of this pestiferous craft, and on the night of June 9, 1772. eight large whale boats, containing upwards of forty bold and resolute men, rowed quietly down the bay to Namquit Point, just below the present village of Pawtuxet, where the "Gospie" had grounded during the day. The vessel was boarded and set on fire, and before daylight the next morning burned to the water's edge. I) uring this attack licutenant I)uddingston was wounded. The audacity of the undertaking was widely commented upom at the time, and every effort was made by the British authorities to apprehend those connected with it, but, notwithstanding the large number of persons involved, the secret was carefully kept, and to this day but few of the names of those who took part in that summer night's work are known. In later years. when all danger had passed. the names of a few became public. The leaders in this expedition were personal friencls of Hopkins. he had commanded ressels in which John Brown, the instigator of it. was interented. and Brown had taken great interest in Hopkins' doings for many years. Abraham Whipple, who commanded the party, was a 
near relative'; he had sailed in the same ship with Hopkins on many privateering ventures, and there was between the two a warm friendship, while Hopkins' own son, John B. Hopkins, at the time a young man thirty years of age, took a prominent part in the affair. This expedition was hurriedly conceived and carried out, there was no time to send messengers to distant parts to secure recruits, and Hopkins, at his quiet home far away from the sound of the drum, which summoned the party together, heard nothing of this water side proposition, but it is quite certain that the doings of that night, and the names of thone participating, were well known to him ere the last spark of the smouldering hull of the Gaspec had ceased to burn.

The year r $77+$ was a year of preparation, and the proceedings of the legislative bodies in the colonies were significant of deep purposes. There was great interest exhibited in the military force. This alone might have caused a suppicion that there was a rebellious spirit in the minds of the people if no other signs were apparent, but there was no lack of

Mraham Whipple married Sarah IJopkins, daughter of John and ratherine Hopkins, Aug 2, 176 . 
such signs. Resistance to British authority and oppression was on the lips of every man. Night after night the tarerns were thronged with men with determined looks on their faces, treasonable sentiments were the subject of their discourse. Men were associating themselves together and obtaining charters for independent military companies. Inflaming articles were being printed on circulars or in the columns of the colonial press, and scattered throughout the land. "A recipe for making gunpowder was included among the useful information in the househotd almanack." The colonies of America were the abiding place of a restless, indignant and excited people. Rebellion was rampant. The year closed and his Britannic Majesty's good subjects in America united in the time honored supplication, "God save the King." 


\section{CHAPTER II}

MILITARY SERVICES ANL TIE BEGINNING OF THE AVERICAN REVOLUTION.

DEFORE the winter's snows had entirely D disappeared from behind stone walls and other sheltered spots, the storm burst that had been brewing so long. In the grey of early morning, on April 19, 1775, the yeoman soldiery of Massachusetts and the King's troops met in a bloody encounter in the highways of Concord and Lexington. Actual warfare had commenced. Three days later the General Assembly of Rhode Island met at Providence; it was the last session previous to the Vlay session, when the new government took its seat for the ensuing year.

There is no stronger way of showing the temper of the people at this moment than by the proceedings of this session. Every measure considered was for the defence of the colony. Committees were appointed to procure lead, bullets and flints; the charters of two of the independent military companies 
were amended and the two organizations consoliclated. A committee previously apspointed to proportion the powder, lead and flints among the several towns made its report. The eleventh day of May was set apart as a day of prayer, fasting and humiliation. A committee was appointed to wait on the General Assemls] of Connecticut "to consult with them upon measures for the common defence of the live New England Colonies." A committee was appointed to take the care of the camnon, powder and other warlike stores in the magazine, at Providence. An army of fifteen hundred men was ordered raised "to repel any insult or violence that may be offered to the inhabitants and also, if it be necessary for the safety and preservation of any of the Colonies, to march out of the Colony, and join and conperate with the forces of the neighboring Colonies."

The passage of this resolution was not without opposition. Joseph IVanton and Darius Sessions, (iorernor and I)eputy (iosernor respectively, opposed it, as did also Thomas Wickes and Villiam Potter, two of the Assistants. The grounds of their opposition, as stated in the protent which they subsequently filed, being "that such a meanure 
will be attended with the most fatal consequences to our Charter priviledges; involve the country in all the horrors of a civil war; and as we conceive is an open violation of the oath of allegiance which we have severally taken, upon our admission into the respective offices we now hold in the Colony." At the spring election Wanton had been reelected Governor; he refused to issue commissions to the officers appointed to command the troops to be raised; to attend the General Assembly or take the oath of office, and even neglected to issue the proclamation for the observation of the day of fasting and prayer designated by the legislature.

His position at this critical period was at once discovered, and measures were taken to deprive him of all his powers. Every authority was forbidden to administer to him the oath of office, and, that the business of the colony might not be hampered, the Secretary, Henry Ward, was authorized to sign all commissions to officers, both civil and military; the Deputy Goremor was clothed with certain powers, and the affairs of Rhode Island went on under the leadership of Nicholas Cooke, who had been elected beputy Governor. 
The excitement caused by this action of the Gorernor was soon followed by more important and alarming events; the business of the government howerer wan soom straightened out, and the officers elected to command the amy of observation, as this military body heretofore ordered to be raised was called, received their commisions, duly signed by Henry IVard, in time to assume their positions and participate in the fight of Bunker Hill. The result of this engagement filled the people of Rhode Island with alam, but its effect throughout the colonies was encouraging and significant, and Franklin wrote, "Americans will fight, England has lost her Colonies forever."

The alarm felt in Rhode Island was not that of fear for the success of the cause, but a fear that from her exposed situation, and the proximity of the enemy, she would be surrounded and made helpless before any effort could be made at resistance. Briti-h ships of war were cruising about in Narragansett bay, a formidable army was only a day' march to the northwarl. It was time for immediate action for defence. Aleady the firs naval engagement of the revolution had taken place. On the fifteenth of June one 
of the sloops belonging to the colony, commanded by Captain Abraham IVhipple, had attacked a tender of the British frigate Rose, chased her ashore on Conanicut Island and captured her.

On the 28 th of June, I775, the General Assembly met in Providence, to which place all the records and treasure of the colony had been removed some time before, from Newport, then the seat of the colony officess.

A signal station was ordered established at Tower Hill, a commanding eminence in the southern part of the colony, and Job Watson appointed signal officer, to give intelligence if any " squadrons of ships should be seen off." Beacons wert also ordered set up in various parts of the colony, to alarm the country in the case of the approach of an enemy. On the soth of July the people awoke to a stern realization of the situation of affairs. James Wrallace, commanding the british flect in Rhode Island, assembled his ships in line of battle before the town of Newport, and threatened to fire upon it unlen the authorities complied with his request for provisions for his men.

At Providence this new's was the subject 
of great concern, and, on the 31 st of July, the Providence town meeting wan convened, and leputy (iovernor Cinske eleeted moderator. Stepo were at once taken to defend the town, and fortifications were ordered erected on a high hill, called fox Hill, commanding the harbor. The comstruction of this work was placed under the control of Captain Nicholas Power, and he was ordered to consult and advise with (aptain Esek Hopkins, Ambrose Page, Captain John Updike, Samuel Nightingale, Jr., Captain William Earle, and Captain Simon Smith, who were appointed a committee to regulate the conduct of the battery to be established at this point. Most of these men were sea captains who had sailed on privateers, and were doubtless selected om account of their experience in the handling of heavy guns on ship board. Esek llopkins thus entered upon a quasi military career remarkable as it was brief. The knowledge of the handling of great sum was limited almost entirely to that obtained on ship board; there was but one fort in the colony at this time, located on Goat latand. in Newport harbor. This committec prepared a set of rules or regulations for the 
conduct of this fort, which, in itself, is a strong defence of the charge that they were military men. It was nearly a month after their appointment before they evolved these regulations and submitted them for the approval of the town, before putting them into effect; such were the crude methods in the early days of the Revolution.

"Regulations of the Fox Point Battery, Drawn by committee. Presented to the Town in Town Neeting August 29 I 775.

Voted one capt E Hopkins be appointed to commd the Battery at Fox Hill.

Voted one luft that Samuel Warner

Voted one gunner Christopher Sheldon

"do 7 men to each gun Including officers that such be select'd from the town Inhabits. as are acq'd with the use of Cannon and doe not belong to Any of the Independt. Companys who Attending this Duty be excused from the Militia Duties.

Voted that the Battery compy Appt a capt \& gunner for Each Gun out of their compy.

Voted that upon any person quiting the Battery compy the officers thereunto Belonging have power to sellect others as above said to keep their number complete. 
Voted that two Persons be appid to Guard said Battery on Day who shall attend there on morning to Relieve the Night watch and Tarry until the Evening watch is Sett.

Voted that the Great Guns be No \& Each persons name who belong to said Guns be Vrote on a Card \& stuck on the Gun they may belong to that they may know where to repair in case of an NlarmVot'd that the Capt. I ieut \& Gumner of said Battery have the Care of preparing $\&$ keeping the Stores Belonging Thereto in Ciood Order.

Voted that the Battery Compy Exercine their cannon once a month or oftener to Perfect themselves in the use of Great ciuns. it is recommended that 2 more is pounders be mounted at the Battery at fox llill.

WILlian EARLE

Simon Simti

Jom UpDike Committie.

EsEk HOPKINS

Ambrose Page

Same. Nightingaid Jk."

In order to facilitate the eonduct of public business during the time when the 
General Assembly was not in session, a committee had been appointed, called the Recess Committee, to act during the interim with full power in the premises. The situation at Newport, and indeed throughout the southern portion of the colony, demanded that a competent officer backed by a military force be located there, to protect the people from the outrages being carried on. This committee, therefore, selected Esek Hopkins for the position, and he was duly commisioned Commander-in-Chief, with the rank of Brigadier-General.

The commission issued to Hopkins and to William West, his able lieutenant, is yet preserved. It is signed by Nicholas Cooke, Deputy Governor, comntersigned by Henry IVard. Secretary, and dated October 4, I 775. He was not appointed to this position by his brother, formerly the Governor, as has been stated.' His peculiar fitness for the responsibilities involved was the only consideration. The position needed a man of judgment and fidelity, and such a man was Esek Hopkins.

The position to which Hopkins was thus assigned was one requiring the greatest tact 


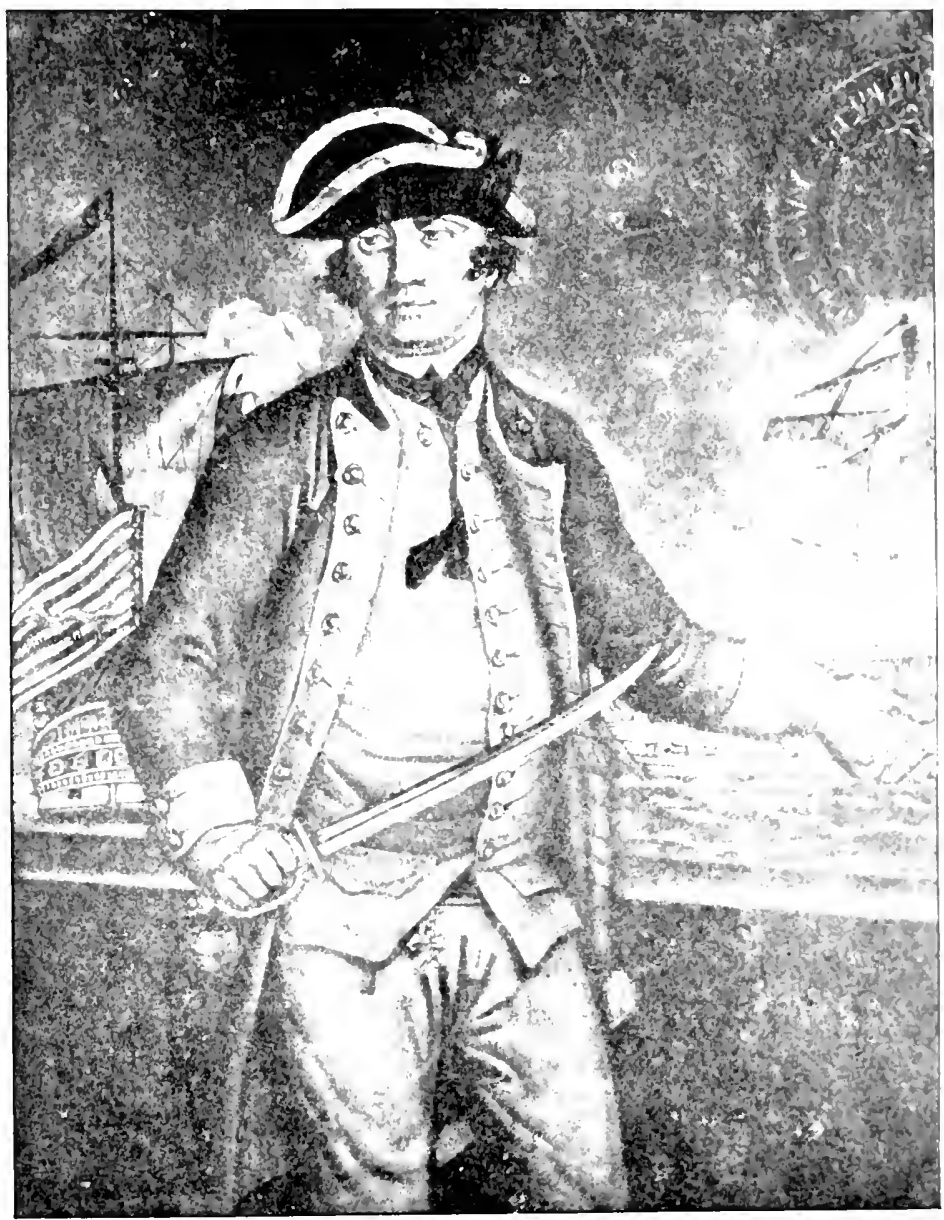

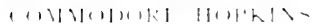

lintratt liate 

and the exercise of a wise diseretion. The British commander, Wallace, backed by a formidable fleet, well manned, and well armed, was lying before the town. Ile was in a position to distress the inhabitants with little or no activity, and to destroy the town itself with comparative ease.

He demanded provisions for his fleet. which the town had been prohibited by the colonial authorities from furnishing. Newport was in a desperate situation.

To this condition General Hopkins first addressed himself; with a force of about six hundred men he established quarters in the town of Niddletown, adjoining Newport. and immediately undertook to straighten out the troublesome affair. L pon the refusal of the town authorities of Newport to furnish the supplies demanded, Wallace had closed the port. All ferry boats, market boats. fish and wood boats. were prevented from coming to the town. P'rovisions, wood and other supplies were thus cut off, and the town was "exposed to all those dreadful consequences which must inevitably arine through the want of the common necessaries of life." So desperate had the position become that the town council of Newport. 
after seriously considering the whole matter, prepared a memorial to the General Assembly, in which they prayed for some relief. The safety of the town demanded that some concessions be made, and upon the promise that Wallace would raise the blockade, negotiations were permitted, and General Hopkins was directed to regulate the supplying of the ships with provisions. Additional instructions were also forwarded to him at this time, and there is a firmness and determination in these directions more significant than would first appear, for it was ordered that he, "from time to time, remove the troops under his command from place to place as he should think may best tend to the general safety, and the peace and happiness of the town of Newport; paying the greatest attention to, and having the tenderent concern for, the true and lasting peace, support, and relief thereof, still haring an eye and just preference to the general safety, and the common cause of America."

A consultation was held between the town authorities and the British commander, and a plan discussect for some concessions. Both sirles faced the situation squarely, and Wallace declared a truce, uncler the conditions 
specified in the following letter, sent to the town council of Nemport:

"I will suspend hostilities against the town till I have further orders, upon their supplying the Kings ships with fresh beef. Sc. Let it remain nester. The ferry and market boats to supply it ummolested. If the rebels enter the town, and break the neutrality, I hold myself disengaged and at liberty to do my utmost for the King service.

$$
\text { J.MILS IVALALE. }
$$

His Majesty's ship, Rose."

There is no date to this letter, it was published, however, in the Providence diastle, on December 9, 1755, in connection with other correspondence regarding the troubles at Newport it was written howerer previous to Norember 15, for it is referred to in a letter of Hopkins' of that date. Thus, nearly eight monthe before the Ineclaration of holependence, the condition of war between bingland and the forcen of the colony of Rhode Island had been recognized by James IVallace, commander of the liritioh fleet in Rhode Island. Ile admits hostilities and rebellion, declares the people of Rhorle 
Island rebels, arranges under a truce a neutrality, and accords belligerent rights to the "rebels." Such a condition did not exist between the two opposing forces around Boston, but on the fifteenth day of November, 1775, Esek Hopkins, commanding a mere handful of soldiers, of the Rhode Island militia, was arrayed against Great Britain in open warfare.

By the terms of this truce, General Hopkins was prohibited from entering the town with his troops, Newport was to supply the flect with provisions: in consideration of which the sources of her supplies were to remain ummolested. In the arrangements for the carrying out of the torn's part of the neutrality. Hopkins had the entire management and direction. He appointed Samuel I yer, Escl., of Newport, to superintend the delivery of the provisions.

In conducting these negotiations Hopkins showed himself to be possessed of sagacity, quiet firmness and discretion; in character rery different from the irascible, irresponsible man, whom his enemies later represented him as being.

Without coming to an actual conflict of arms fwhich might have proved disastrous 
to the Rhode foland forcent, he did succeed in bringing about a concition of affairs in which the british commander taritly recesnized him as the duly comminsioned commander of an army rained by the legislature of the colony of Rhode Island, as comstitutional a boly as the parlinment of cireat Britian, and one reengnized for wer a century by British authoritien as such, by submitting to the orders and directions of Samuel Dyer. Hopkins' duly authorized agent.

The contentions between Wallace and the town authorities of Newport, reyarling supplies for the ministerial fleet, were prolonged through the entire time that Iopkins was in command of this station. The correspondence passing between Lopkins and the town of Newport discloses a determination on the part of the (iencrial to conciliate the differences, yet to manane the affairs frmly, avoiding if posible cetreme measures. From his "I Leadquarters. Nov $151775 "$ he writes to the town of Newport.

"Genthemin

I received a copy of a letter. signed by James ilallace, Commander of his Majesty's ship Rose together with your 
approbations of the contents: In answer to which I am to let you know, that I will permit you to supply the ministerial navy now in your harbor, with fresh provisions, \&c. provided the quantity be ascertained, and is no more than is sufficient, or has been heretofore made use of, and that under the inspection of a man that I shall appoint and authorize, and not otherwise, provided that he, said Wallace, with all the vessels and boats under his command and direction. let all the wood, market, and ferry boats pass $\&$, repass together with their passengers and effects unmolested and unexamined, on failure or breach of which I shall immediately stop the supplies. This is all that can be expected in supplying the ministerial navy, except they remove out of cannon shot of the town of Newport.

I am, gentlemen, your humble servant Esek Hopkins, Brigadier General."

These conditions the town desired modified, and the next day sent to him the following:

SIR

$$
\text { "Newport, Novi 6, I775. }
$$

Your proposal for settling a truce between the town of Newport and Capt. 
Wallace we have received and examined, and as the word unexamined in your prosposal seemes to us will not be complied with by Capt. Mallace, requent you will leave the same out, as we apprehend it contraly to his instructions and the acts of P'arliament, and are fearful it will greatly imperde the wished for truce. I am, in behalf of the Town Council of Newport, Sir, your very humble servant,

Méman Commatox Council Clerk.

To Esek Hopkins, Esq., Brigadier (ieneral of the forces in this Colony:"

To this proposition llopkins reluctantly consented in the following brief reply:

$$
\text { "Hean Quarteks Nor. 16.1755 }
$$

To the Morshipful Town Council of the town of Newport.

Genthenhen

1 reccived yours this day, wherein your request the word unexamined may be left out of my proposal, which I now give you leave to do; but think it would be more for your interent to let it remain.

I am, gentlemen, your humble serrant Esek Horkass Brigadier General." 
Negotiations were finally concluded and a more peaceful result attained than had been anticipated. In riew of the threatening aspect, many of the inhabitants of Newport left the Island, taking all their property with them, and, it is said, "For four days the streets were almost blocked with carts and carriages of every sort seeking a place of safety."

From that day Newport, as a commercial center, began to wane. Previous to the Revolution the trade of Newport was greater than that of New York. During the three months ending the soth of October, I769, 3.000 hogsheads of molasses were entered at the Custom House, to say nothing of the quantity that was "run in," as smugghing was sometimes delicately called.

It is doubtful if Wallace ever intended to fire upon the town. It was of too much importance as a rendezvous and military station to be destroyed, and, indeed, for more than three years was occupied by the british as such. In addition to the powers conferred upon Hopkins as commander of the military force, he was specially directed, in the commission issued to him, to apprehend George Rome, a merchant of Newport, 
he having "greatly aswisted the linemy and proved himself entirely inimical to the l.iberties of America." No part of the collony" sheltered more of the Tories and Rogalisto than Newport. Many of the mont wealthy and influential men in the town were included among thems of these George Rome was the most prominent and bitter against the independent movement in the colonices. Cieorge Rome, "a gentleman of estate from Old England," was a wealthy merehant of Newport, where he resided winters. He was the owner of a fine estate in North Kingstown, R. I., with an elegant mansionbouse which he occupied during the summer. This residence he called batchelors Hall, "my little eountry villa." The house and the grounds around it were the most elaborate of any in the colony. Here. surrounded by a large circle of friends, he entertained in a sumpturus manner. Invitations to partake of his hospitality indicate somewhat the nature of the entertainment provided, for, writing to one of his friends. he says: "My compliments to Colonel Stewart: may I ank the faver of you both to come and eat a Christman dinner with me at Batchelors Ilall, and celebrate the 
festivities of the season with me in Narragansett woods? A covey of partridges or bery of quails will be entertainment for the Colonel and me, while the pike and pearch pond amuse you." In the Stamp Act excitement he upheld the crown, and much bitterness was aroused against him. In 1773, Dr. Franklin, while in London, obtained a letter of Rome's which he transmitted to this country. A copy of it was forwarded to Rhode Island, and Rome was called to account for the scandalous aspersion contained in it.

This letter was deroted to a general abuse of the government, in which he attacked the legislature, the courts and juries of the colony, advised that the charter be annulled and a government more dependent on the crown be created. He asserted that "the colonies have originally been wrong founded. They ought to have been regal governments, and every executive officer approved by the King. Until that is affected, and they are properly regulated they will never be beneficial to themselves nor good subjects of Great Britain." This letter was written from his Narragansett home, on I)ecember 22, 1767. When this attitude 
of Rome's became known it produced murh excitement in the colony. Resolutions condemning his actions were passed in epen town meeting in several of the towns, and at the October sussion of the (iencral Assembly, in r77t, he was brought before that body on a warrant to answer for his aspersions on the government. His answers, when questioned, were insulting and evasive, and he was adjudged in contempt and ordered committed to the common jail in South Kingstown until the close of the session. Here he remained for some time. and upon his release, in fear of bodily harm. for the most intense feeling had been aroused against him, he fled on board the british frigate "Rose", then lying in the bay. Ili estates were confiscated, together with those of others of his stripe. The order for his apprehension, given to Hopkins, was subsequent to this, and it is supposed that he afterwards returned to Newport and continued his seditious practices IThat erentually became of him is not stated.

But Hopkins did not disregard others in Newport who were inmical to the cause of liberty. He acted on the spirit of his commission if not by direct order, and took 
possession, in behalf of the colony, of the entates of Benjamin Brenton, the heirs of Andrew Oliver, deceased, Jahleel Brenton, and Thomas Hutchinson, as well as the estate of Rome, and reported his action to the Governor. These estates were declared confiscated and placed under the control of persoms appointed by the General Assembly to manage, and the action of Hopkins approved by that body; it even went farther and declared that all deeds executed since the fifth of October, I 775, by certain other persons of Tory proclivities, be null and void. A year later the property thus confi-cated, belonging to George Rome, was sold at public vendue to the highest bidder. and thus, says Updike. "the great estates of $\mathrm{Mr}$. Rome were lost to his family forever."

The duties devolving upon Hopkins while in command of this military post were varied and perplexing, requiring the exercise of great judgment and a wise discretion.

The situation of affairs was most delicate, and any misstep would have brought about a conflict between the King's forces, under Wallace, and the colony troops. During his command on Rhode Island a sloop, with her cargo, arrived in the Seaconnet river on 
the east side of the island of Rhode Inlanel. in charge of Captain lsaac Eslick, of lirintul. R. 1., and by him was turneed oxer to the care of Ilopkins. The arrival of this veresel disclosed a sperit of adrenture and daring which characterized the ship masters of the times.

Captain Eslick, in command of a small trading sloop, had been captured at sea by one of the English wat vescels cruising off the coast. I prize master and crew hat been put aboard and ordered to take her into Boston, while Eslick had been detained aboard the British sloop of war," liper." Xot long after this the British sloop sighted and overhauled the sloop "Polly," belonging to New York, commanded by Captain Simuel Barnes, and bound thence for Antigua. A midshipman, as prize master, and seseral hands, were put on board, with orelers to proceed with the vessel to boston. Ealick was also transferred to the shop to act as pitot, encouraged with the promise that if he successfully and faithfully piloted her into boston harbor he should be rewarded with having his own boat with her cargo restored to him. Esick soon established friendly relations with two of the original crew of the 
sloop, and together they determined to outwit the prize master and cary the sloop into Rhode Island. It was a most daring project, and one having little promise of success. Wallace's ships were cruising about the lower part of Narragansett Bay, and even extending their cruises, on occasions, into Long Island Sound, so that the chances of successfully ruming this blockade were well. nigh impossible. Nevertheless, Eslick laid his course, and with the assistance of his two accomplices the ressel was successfully brought into the Seaconnet river and turned over to Hopkins. By this exploit Eslick lost all chance of redeeming his own property, which was still in the hands of the enemy, but at the risk of his life and the sacrifice of his own vessel and cargo he had saved valuable property belonging to others. The circumstances of his action were communicated to the colony atithorities, and the General Assembly soon after ordered two hundred and fifty dollars paid to Eslick and fifty dollars each to his two associates in the business. The payment of this amount was made a lien upon the sloop and her cargo, and Hopkins was directed to hold the ressel until these amounts were paid, 
which was promptly dome, the owners, douletless, being well pleased to escape so earily from what otherwise would have becm a total loss. The troubles which hat entinued between the colony offeces and the duly elected executive, (iovernor 11 anton, were now brought to a close, the cieneral Assembly passing an act declaring the offece of governor vacant, and IJopkins, with Captain Joseph Anthony and Mr. I'aul Mlumford. Were appointed a committer to receive from the deposed governor the charter and other state papers in his hands. The duties devolving upon General Hopkins were now becoming so arduous that he was authorized to appoint a secretary: a commissary and a sutler were also oredered attached to the brigade under his command. Early in October, Mallace, having harraned Newport and the farmers along the southern bay side, moved his fleet northward to the harbor of Bristol, where, on the 7 th of Uetober, I775, he assumed a threatening attitude and proceeded to make the same demands for provisions. In order to give his demand a show of determination he fured a few shots into the town, without doing any damage save producing the greatent 
excitement and fear among the inhabitants. The town authorities wisely complied with his demands and furnished him forty sheep, and the fleet withdrew after landing a small force and plundering neighboring farms. All of the towns on the sea-coast were open to such attacks, and, had Wallace desired, he might have sailed even to Providence and enforced similar demands. In view of the unprotected situation of the colony Hopkins was recalled to Providence, and, with Joseph brown, dispatched on a tour of inspection to ascertain what places should be fortified and in what manner. Colonel IVilliam West was left in command of the troops. The result of this committee's labor was a series of fortifications extending along the bay side at all exposed points, the military force of the colony was largely increased, and garrisons established composed of the companies in the respective towns where these works were located.' Cannon were shipped to the Island, and a number of rs-pound guns in the fort already constructed at Providence were put on carriages for field artillery.

\footnotetext{
"See my "Revolutionary Defences in Khode Island."
} 
The naval force of the colomy wat atsemented and all precautionary methode of defence provided that were deemed meressary. Thus matters went on until /lopkins received his appointment from Comgress an Commander of the Continental Nary; his services as a military eommander corering a period of two monthe and eighteen days. I)uring this time his services had been entirely administrative, the trocpse under his command had never been brought inter action, and, so far as there is any evidence. not a charge of poweler had been bermed. This hardly justifies the assertion, made by a recent historical writer, that in the apporintment of Hopkins to the position of Commander-in-Chief of the Continental fleet Congress erred in appointing a soldier rather than a sailor. Surely a service of thirty years and more on the sea, most of the time as master of a versel, would seem to entite a man to a greater proficiency as a master mariner than three months service would entitle him to be classed as a military commander.

Hopkins was a man of many capalpilities; as a politician be seems to have been wise, active and ageressive: as a military 
commander firm, careful and discreet. In his subsequent career, when he entered upon broader fields of service than those afforded in his own native colony, he became the subject of criticism and abuse, but above it all his noble character, high integrity, and pure patriotism show out distinct and clear. 


\section{CIIIPTER III}

THE ORIGIN OF A NAVY AND TII: NIPOINI-

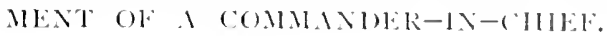

TO a maritime colony like Khode Liand. I the importance of having a naval contingent was recognized at the beginning of the trouble with the mother country. Is early as June, 1775, when the (ieneral issembly had ordered an army of fifteen hundred men raised for the defence of the colony, provision had also been made for the fitting out of two suitable ressels "to protect the trade" of the colony.

The largest of these rensels was manned with a crew of eighty men exclusive of officers, and equipped with ten four-pounders and fourteen swivel sums, and named the "Washington." The smaller vessel was called the "Katy" and manned with a crew of thirty men.

Abraham Whipple, who had seen service in the old French War, the commander of the "Gaspee" expedition, and who afterwards 
beld important commissions in the Continental Nayy, was appointed commander of the larger ressel, and commodore of the little fleet which, besides these two vessels. consisted of two row galleys of fifteen oars to a sicke, mounting each an eighteenpounder in the bow and carrying a number of swivel guns. Each galley was fitted to accommodate a crew of sixty men. Hardly had this fleet been put in commission, in fact before the row galleys had been fully constructed, when the commodore's ship and a tender to the frigate "Rose," of Wallace's fleet, met in conflict, and in the engagement which followed, Abraham Whipple had the honor of discharging the first gun upon the ocean, at any part of his Majesty's Navy in the American Revolution.

Some time previous to the fourteenth of June the British commander had captured two packets belonging to some of the inhabitants of Providence: one of these Wallace had fitted up as a tender, which was being uned to intercept the coasting trade and annoy all craft sailing on the bay.

This being brought to the attention of Deputy Crovernor Cooke, for the colony was without a gewernor at this time, on account 
of the IVanton episode, he dispatched a spirited letter to Wallace on the 1 t th in which he demanded the reasons for his action in stopping vessels and gencrally amoying the inhabitants. He also demanded the return of the packets thus seized. IVallace was alway's brief and to the point in his official correspondence, and on the fifteenth he sent the following answer:

$$
\begin{aligned}
& \text { "His Majesty's Ship Rose } \\
& \text { Rhode Island June I } 5 \text { I } 775 \text {, }
\end{aligned}
$$

SiR: I have receired your letter of the

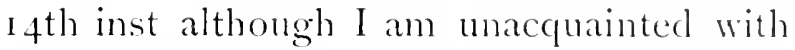
you or what station you act in, suppose you write in behalf of some body of people; therefore previous to my giving an answer I must desire to know whether or not you or the people on whose behalf you write, are not in open rebellion to your lawfull sovereign and the acts of the British legislature

I am sir your most humble and obedient servant

$$
\text { To Nicholas Cook Esq." Jas. Marhace }
$$

Before the ink with which this letter was written had fully dried, one of these rery 
packets that the Deputy Governor had demanded restored, and which had been fitted as a tender, was chased ashore on Conanicut Island in Narragansett Bay and destroyed. The details of this first engagement on the sea between Great Britain and the colonies are obtained entirely from British authority, and are thus described by the commander of the tender, Master Savagre Gardner, in his $\log$ yet preserved in the Jritish archives. "About 6 o'clock as our tender was standing off and on between Gold Island and the North Point of Conanicut lsland they saw a sloop standing down the river. Our tender hove too to speak her. She hailed the tender and told them to bring too directly or he would sink them directly. Fired a shot which the tender returned and kept a smart fire on both sides for about half an hour when another sloop joining and bringing our tender between the fires that they had no opportunity of getting off, tho made two or three tacks right off. By accident the Swivel cartrages blowing up and the musquet cartridges near expended. Thought most prudent to run the Tender on shore to save the men which was accomplished near the N. P. of Conanicut 
Island. Only a petty officer and one man wounded by the powder blowing up, Thes constant fire on them at their landing. Night coming on they being closely pursued separated and got safe on board the ship by noon next day.

Gumners stores lost in the slonp, riz. Bright musquets 11 , Marines ditto 7 , Cutlasses with scabbords 17, balyonettes with scabbords 9, Marines ditte 7 , Ships piotols I 2, cartouch Boxes, with belts and straps 12, Swivels t, Aprons of lead $t$ Swivel irons and saddle one each, l'ikes s, Cances of wood 2, Musquet cartriege box 2, l'owderhorns 3, priming irons 6, Powder in Swivel cartridges 50 Pounds cartridgers. 9 Pounders 2 do, $\frac{1}{2}$ Pounders fo Round Shot. 1), to Grape to, Musquetshot 15 pounds. Pintol Shot 9 Pound.

Boatswains Stores vi\%. Rope zinch zo fem., I 2 inch 50 fem. bilocks of 2 inch double 2, larger of 8 inch 3 , thimbles 12 , Marline spikes 2. 1 Foremast steering sail and a mizr. I. J. (i. Sail I llatchett, 2 Iogglines and 15 llammocks.

Carpenters stores vi\% I driveryard, I fore J. Mast steering Sailyard, I Tarperline. Pursers stores vi\%, a Puncheon, a barrel." 
This exploit of Whipple's, together with the knowledge that he had been instrumental in the destruction of the "Gaspee," greatly exasperated Wallace, and he addressed him the following succinct and highly expressive letter:

"Sir: You Abraham Whipple, on the Ioth June I 772 burned his Majestys ressel the Gaspec and I will hang you at the yard arm.

$$
\text { JAMES W'ALLACE." }
$$

To which Whipple briefly replied:

"Sir James Wallace Sir Always catch a man before you hang him

\section{Abrahan Whiple."}

This little squadron was kept busily engaged in patrolling the waters of the bay, and at the time of the threatened attack on Newport was ordered to coöperate with the militia under Hopkins. While thus engaged a request was received from the Continental Congress to Governor Cooke that the Rhode Island fleet be clispatched to intercept two ships, which, it was learned, were bound to Canada with military stores, but the larger ship being then on a 


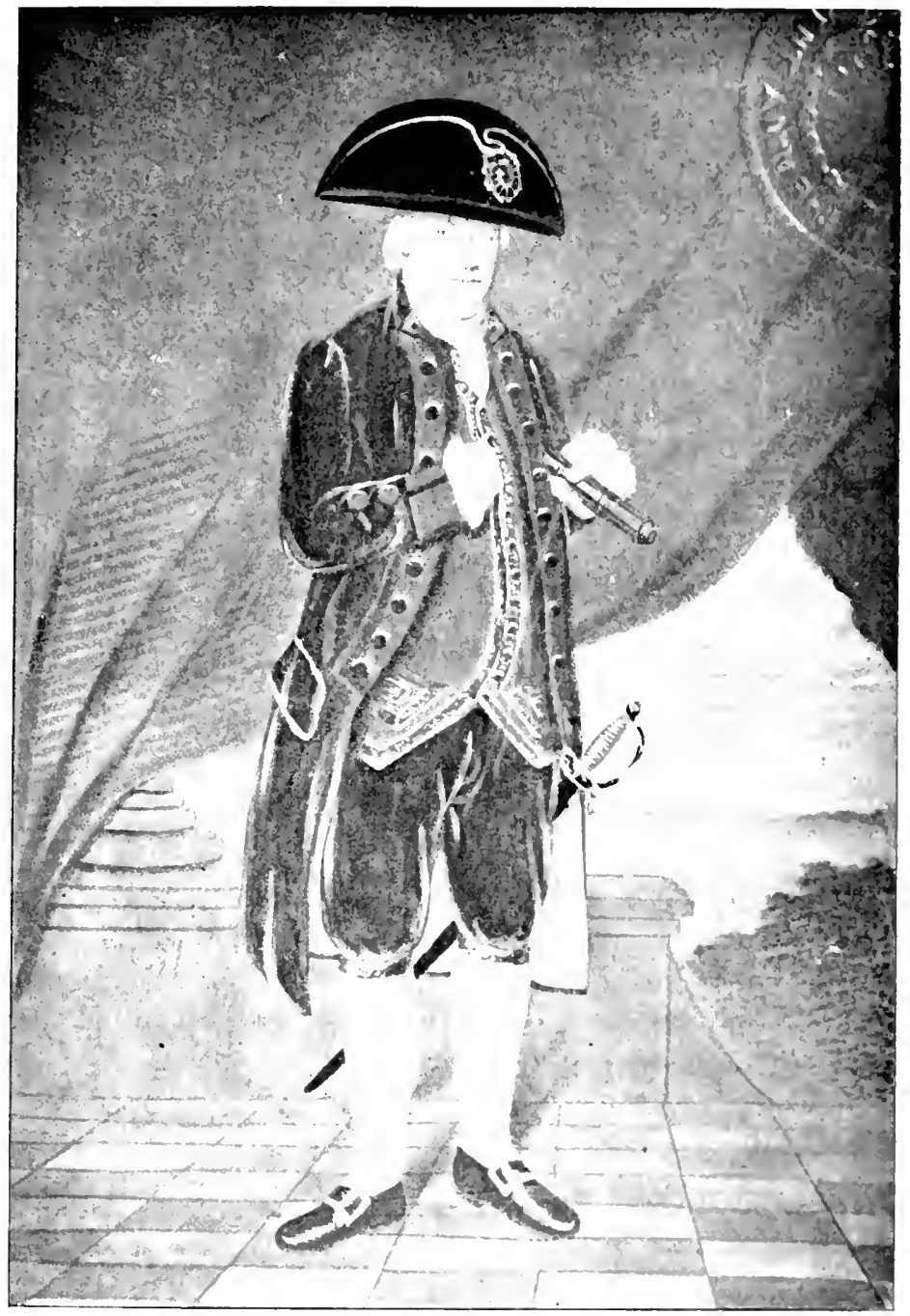

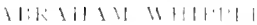



voyage to Bermuda, and the situation in Rhode Island remaining unchanged, it was deemed unadvisable to send the smaller vessel on this expedition.

On Monday, the 2 sst day of August, 1775. the General Assembly of Rhode lstand convened at Providence. It this session the furst suggestion for the establishment of a Continental fleet was marle, and from this suggestion the American Navy owes its origin. It was embodied in a resolution of instructions to the Rhode Island delegates to the Continental Congress, passed on August 26, for them to present to that body, that the sentiments of the colony might be plainly set before it. This resolution, with its preamble, cleared the way for another resolution passed on the following May, whereby Rhode Island severed all allewiance to Great Britain two months to a day before that remarkable declaration was made at Philadelphia. These instructions, prepared by the legislature of Rhode Island, were as follows :

"Whereas, notwithstanding the humble and dutiful petition of the last Congress to the King, and other wise pacific measures taken for obtaining a happy reconciliation 
between Great Britain and the colonies; the ministry, lost to every sentiment of justice, liberty and humanity, continue to send troops and ships of war into America, which destroy our trade, plunder and burn our towns, and murder the good people of these colonies, -

It is therefore roted and resolved, that this colony most ardently wish to see the former friendship, harmony and intercourse, between Britain and these colonies restored, and a happy and lasting connection established between both countries, upon terms of just and equal liberty; and will concur with the other colonies in all proper measures for obtaining those desirable blessings.

And as every principle, divine and human, require us to obey that great and fundamental law of nature, self-preservation, until peace shall be restored upon constitutional principles; this colony will most heartily exert the whole power of government, in conjunction with the other colonies, for carrying on this just and necessary war, and bringing the same to a happy issue.

And amongst other measures for obtaining this most desirable purpose, this Assembly is persuaded, that the building and 
equipping an American flect, as seom as possible, would greatly and essentially comduce to the preservation of the liven, liberty and property, of the goond perple of these colonies: and therefore instruct their dele. gates, to use their whole influence, at the ensuing Congress, for building, at the Cimtinental expense, a fleet of sufficient force, for the protection of these colonies, and for employing them in such manner and places as will most effectually annoy our enemies. and contribute to the common defence of these colonies.

And they are also instructed to use all their influence for carrying on the war in the most vigorous manner, until peace, liberty and safety, be restored and secured to these colonies upon an equitable and permanent basis.",

On Tuesday, October third, these instruc tions were presented to the Continental Congress by one of the delegates from Rhode lsland. No action was taken om that day relative to the suggestions contained therein, but it was referred to the following Friday for consideration and mate

${ }^{1}$ Records of the Colony of Rhode Islanul, vol. 7. p. $36 \mathrm{~cm}$. 
the special order of the day. On that day, however, it was again referred, finally coming up for action the serenth day of October. The suggestion of a measure of such extensiveness produced a spirited debate, participated in by Samuel Chase, of Maryland; Eliphalet Dyer and Silas Deane, of Connecticut; Stephen Hopkins, of Rhode Island; Robert Treat Paine, Samuel Adams and John Adams, of Massachusetts; the Rer. Dr. Zobly, of Georgia; Peyton Randolph, of Virginia; John Rutledge and Christopher Gadsden, of South Carolina. "It is the maddest idea in the world to think of building an American fleet," said Chase, "its latitude is wonderful we should mortgage the whole continent," but he added, I believe, "we should provide, two swift sailing ressels."

Gadsden was inclined to be cautious about accepting so broad a measure as the "Rhode Island plan." He believed, however, that it was absolutely necessary " that some plan of defense. by sea, should be adopted."

John Rutledge wanted to know how many ships were to be built and what they would cost; until this was stated he could not form an opinion; and, that the whole 
subject might come before the Congress in a comprehensive manner, he offered a resolution that a committee "be appointed to prepare a plan and estimate of the Anerican fleet." This resolution was seconded by the Rev. Dr. Zobly, of Ceorgia, who adted: "Rhode Island has taken the lead I move that the delegates of Rhode lskand prepare a plan giving us their opinion :"

Samuel Adams suggested the difficultien such a committee would be under without knowing the wishes of Congress: "such a committee can't make an estinate, until they know how many ships are to be built," said he.

The debate then became general, and is delicately alluded to by John Adams as "lightly skimishing." Gadsden charged his associates with trying to throw the whole subject into ridicule. He beliered that so important a suggestion should be seriously considered "out of respect to the colony of Rhode Island who desired it." Deane resented the attempt to make light of so important a subject: "let it be seriously" debated," said he, "I don't think it romantic at all."

John Adams, in his memoranda of debaten 
in the Continental Congress, notes that: "The resolution to refer the matter to a committee was defeated." It appears, however, that it was subsequently so referred, for on the $\mathrm{z}_{\text {th }}$ of October. Congress taking into consideration the report of the committee appointed to prepare a plan for a nary, after some debate. roted "that a swift sailing renel to carry ten carriage guns and a proportionable number of swivels with eighty men be fitted with all possible dispatch for a cruise of three months and that the commander be instructed to cruise eastward for intercepting such transports as may be laden with warlike stores and other supplies for our enemies and for such other purposes as the Congress shall direct."

A committee was appointed to prepare an estimate of its cost and to contract for the fitting out of the same: it was also decided at this time that another ressel be fitted out for the same purpose, and that an extimate of the expense of this be submitted. Mr. Deane. Mr. Langdon and Mr. Gadoden, were appointed on the committee. On the joth of October this committee submitted its report, and it was resolved "That the second ressel ordered to be 
fitted out on the 1 ith inst be of such size as to carry fourteen gums and a proporttionable number of swivels and men." Twe other vessels were also ordered to be put into serrice, one to carry not exceeding twenty guns, and the other not exceeding thirty-six guns, "for the protection and defense of the United Colonies, as the Comgress shall direct." A navy was now assured; the Rhode Island plan had been accepted. Stephen IIopkins, Joseph l fewen. Richard Henry Lee and John Adams, were added to the committee already appointed to carry into effect the resolves of Congren with all possible speeel.

This committec, consisting of reven members, was known as the Naval Committec. This committee immediately addressed itself to the important duty referred to it.

John Adams afterwards wrote: "The pleasantest part of the labors for the four years I spent in Congress, from 1774 to I778, was in the Committee on Naval Affairs. Mr. Lee and Mr. Gadsden were sensible men and rery cheerful, but Gorernor Hopkins, of Rhode Island, above seventy years of age, kept us all alive. Upon business, his experience and judgment 
were very useful. But when the business of the evening was over, he kept us in conrersation till eleven and sometimes twelve o'clock. His custom was to drink nothing all day until eight in the evening, then his beverage was Jamaica spirits and water. It gave him wit, humor, anecdotes, science and learning. He had read Greek, Roman and British history, and was familiar with English poetry, particularly Pope, Thompson, and Milton, and the flow of his soul made all of his reading our own, and seemed to bring in recollection in all of us all we had ever read *** Hopkins never drank to excess, but all he drank was immediately not only converted into wit, sense, knowledge and good humor, but inspired us all with similar qualities."

Stephen Hopkins and John Adams, representing two important maritime colonies, were the most active and influential members of this committee. They were firm friends then and they remained so ever afterwards.

Christopher Gadsden, another member of the committee, was a friend of Esek Hopkins, and was in constant correspondence with him. 'This committee at once undertook 
the work of procuring and fitting out the vessels ordered, and by the fifth of November, 1775, had so far progresied in the accomplishment of the duty devolving upon it as to select Esek Hopkins, of Rhode Island, as commander of the fleet, and on that day he was officially notified of his appointment. It was undoubtedly the influence of Stephen Iopkins that brought this about, seconded by the friendly interest of John Adams and Christopher Gadsclen. It is not unreasonable to believe that the reputation of Esek Hopkins, as a successful and experienced master mariner, was well known in Philadelphia at that time among shipping merchants and ship masters, and even with other members of the Naval Committee he may have had some acquaintance if not a closer friendship. A Newbern, North Carolina, newspaper correspondent, about this time, refers to Hopkins as "a most experienced and venerable seacaptain." On the day following his selection by the committee for this important and honorable position, his brother sent to him the following letter, expresing the hope that he would accept the appointment. 
"Philadelphia, Norr 6, i 775.

DEAR SIR:

You will perceive by a letter from the Committee, dated yesterday, that they have pitched upon you to take the Command of a Small Fleet, which they and I hope will be but the beginning of one much larger.

I suppose you may be more Servicable to your Country, in this very dangerous Crisis of its affairs by taking upon you this Command than you can in any other way. I should therefore hope that this will be a sufficient Inducement for you to accept of this offer. Your Pay and Perquisites will will be such as you will have no Reason to complain of. Such officers and Seamen as you may procure to come with you, may be informed, that they will enter into Pay from their furst engaging in this service, and will be intituled to share as Prize one half of all armed Vessells, and the one third of all Transports that shall be taken.

You may assure all with whom you converse that the Congress increase in their Unanimity, and rise Stronger and Stronger 
in the spirit of opposition to the Tyrannical Measures of Administration

I am your affectionate Brother

STEP IIORNS.'

It was while Hopkins was in command of the military force stationed at Sewpert that he received the notice of his appointment to the command of the Continental flect, but it was not until the latter part of December that he was relieved of this command. In the meantime the situation at Newport remaining one of srave uncertainty, Governor Cooke applied to General Vashington for a regiment to coriperate with the Rhode lsland troops in the defence of the island. He also asked that ceneral Charles lee be sent to take command of the post which Hopkins was about to vacate. and on the twenty-first of l lecember, (eneral Lee arrived in Providenee and immediately assumed command of the forces around Newport. I) oring the lime intervening between Hopkins departure and the arrival of General Lee, Colonel William IV ent helel the command of the pont. On the twentysecond day of lecember, the day after

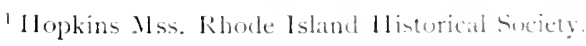


General Lee assumed the command vacated by General Hopkins, Congress confirmed the appointment of Esek Hopkins as Commander-in-Chief of the fleet to be raised, and also appointed the following officers for the sereral ressels:

Dudley Saltonstall,

Abraham Whipple.

Nicholas Biddle,

Captains.

John Burroughs Hopkins, )

John Paul Jones,

Rhodes Arnold,

- Stansbury,

First lieutenants.

Hoysted Hacker, Jonathan Pitcher,

Benjamin Seabury, Joseph Olney,

Elisha VIarner, Second lieutenants.

Thomas IVeaver,

- McDougall,

John Fanning,

Ezekiel Burroughs, Third lieutenants.

Daniel Vaughan,

The rank given to Hopkins was intended to correspond in the navy to that held by General Washington in the army. The title bestowed upon him seems to have 
varied: sometimes he was alderesed an eommodore, sometimes as almiral, while. even in offecial eommunications from the president of Congress and the Naval Committee he was given beth thene, as well an the full title named in the reselution of Congress atponoting him.

Hopkins set out for Philadelphia in the early part of fanmary, in the sloop " Kirtr." afterwards called the "I'rendince," of the Rhode loland naly. This lesed was eommanded by captain Mbraham Mhipple and had also on board a number of seamen who had been enlisted in Rhorle Island to serve in the fleet. After a vosage colivened log taking a small resiel and three prisoners, the "Laty" arrived in Philadelphia, Jannary it. Her arrival was duly communicated to (iosernor Cooke by Samucl Wird, a member of Congress from Rhode Island, on Jantray 10. who said: "()ur seamen arrived here day before yesterday. Thone concerned in the naval department are highty pleased with them. Their arrival gives fresh spirit to the whole fleet."

When Iopkins arrived in lhilatelphica he found a seene of great activity. The Naval Committec had promptly complied i; 
with the directions of Congress, and the hips for the fleet, of which he was to take the command, were being assembled in the I) elaware river.

Eight ressels of rarying tonnage were selected from the available merchantmen, hurriedly altered over for the accommodation of larger crews than they had originally been designed for, and pierced for heary guns. The ship selected as the flag-ship was formerly a merchantman named the "Black Prince." She had recently arrived from London under the command of John Barry. Maclay, in his History of the Nary, says: "She was a small ressel, but was considered a stout ship of her class, and was named the 'Alfied,' after Alfred the Great who was commonly regarded as the founder of the British nary." She carried twentyfour guns, and Captain I)udley Saltonstall' was assigned to her command. The second was called the "Columbus," formerly the

No portrait of Captain sistunstall can be found. His com-

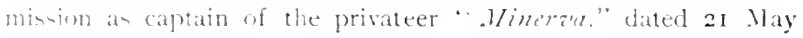

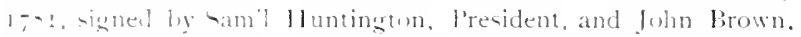
-ecretary to the buard of Idmiralty, is in the posseston of 1 lon. (harles 1. Hoally, librarian of the connecticut state library. () n the back of this comminsion is a description of saltonstall, writen and signed ly (iovernor Jonathan Trumbull, which states 
merchantman "Sally" a thirty-aix gun ship. twelve and nine pounders on two deckis, and forty swivels, and rarying five homdred men, and was to be commanded by (aptain Mbat. ham M'bipple, the captain of the "Katr." which had brought lopkins from l'rovidence to Philadelphia. The thired was a fourteen sum brig called the "Andred Ioria." after" the sreat Genoese admiral of that name," and was commanded by Captain Nicholan bidedle. The fourth was a fourteen grm brignamed the "Cabot," after Sebastian Cabot the disenerer, and was under the command of (ap)tain John Burroughs I Iopkins a son of the Commander-in-Chief.

The " Latr"," of the Rhode l-kand nay. upon her arrival in Philadelphia, was laken into the continental service and named the "Irozidence." "She was named," say foln Adams, "for the town where she wats pur" chased, the residence of (iosernos llopkins and his bother beck, whom we appointed

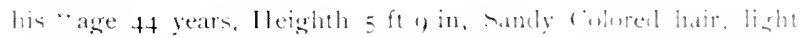

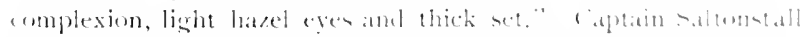

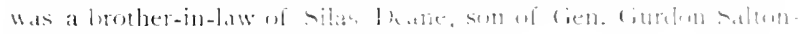

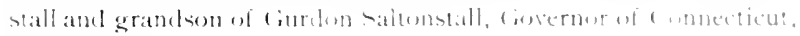
$1,00-1724$.

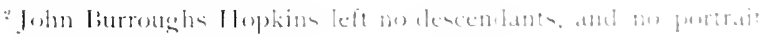
of him is known to exint. 
the first captain." This vessel was a brig and carried twelre guns. The rest of the fleet consisted of a ten gun sloop called the "Hornet," Captain Villiam Stone, and the "Irasp" and "Fly", eight gun schooners.

The " II asp," "Hornet" and "Fly," were expected to be amnoying pests to the enemy, and hence their names.

Un the fifth of January the Naval Committee had formulated their directions to the commander of the new nary in the following :

"Orders and Directions for the Commander in Chief of the Fleet of the United Colonies.

You are to take care that proper discipline good order and peace be preserved amongst all the ships, and their companies. under your command.

You are to direct the several captains to make out and deliver monthly or oftener an exact return of the officers Seamen and marines on board of each respective ressel noting their particular condition and circumstance-also the quantity and quality of provisions and stores of every kind together with the state of the respective ships-which returns or copies of them 
bou are to transmit to Comeres ar at (immmittec by them appointed, to reteive -neh returns, as often as opportunity uffers.

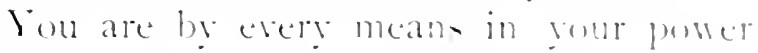
to kecp up an exact correypondence with the Comgress or Committee of Cimerex aforesaid. and with the commander in chief of the Cintinental forces in Imerica.

As by your instraction- vou are imspowered to equip such lesels as may tall into your power, and to appoint officerfor such lesels-as often as thin shall happen you are by the rery firet (y)per. tunity to transmit to Comeres w the Commite aforeate the burthen, fore and manner of equipment of such verects. tor gether with an exact list if such officers as rou may appoint. in order that their appointment may be confirmed by Cingres or others be appointed in their stead.

You will be particulary careful to give such orders and instructions. in writings to the officers under rour command as the good of the service may in crery case require-to devise or adopt and sive nut to the Commanding officer of crery-bip. such signals, and other marks and direction- as may be necessary for their direction. 
You are to take very particular care that all the men under your command be properly fed and taken care of when they are in health, as well as when they are sick or wounded. You will also very carefully attend to all the just complaints which may be made by any of the people under your command and see that they are speedily and effectually redressed for on a careful attention to those important subjects the good of the service esrentially depends.

You are always to be exceedingly careful that your arms, as well great as small, be kept in the very bent condition for service and that all your cartridges, powder shott and every accoutrement whatsoever belonging to them be kept in the most exact order: always fit for immediate service.

You will carefully attend to such prisoners as may fall into your hands-see that they be well and humanely treated-you may also send your prisoners on shore in such convenient places where they may be delivered to the Conventions, Committees of Safety or inspection in order to their being taken care of and properly provided for.

You will also give proper orders and directions to the Captains or Commanders 
of the Ships or Venets under gente commmand in case they should be separated by stress of weather or any other accident in what manner and at what plares they shall again join the lileet.

$$
\begin{aligned}
& \text { STEP Ilopkix }
\end{aligned}
$$

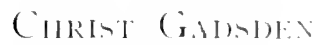

$$
\begin{aligned}
& \text { Shas lome } \\
& \text { Joseph llews." }
\end{aligned}
$$

About the time that Hopkins arrived in Philadelphia, Gadsden, of the Naval Committee, was suddenly called to South Carr. lina, which colony he then represented in congress, to take command of his regiment, the first regiment of foot. (On the tenth of January he sent to Lopkins a letter. detailing, at some length, the situation in Charlestown, and advising him of the men there to whom he could look for advice and assistance. The statements in the letter give unmistakable evidence that the Nasal Committee had contemplated that the theet should be used, in the proposed operation. against the enemy at Charlestown. This letter was as followis: 


$$
\text { "Philad". IO Janly I776 }
$$

I). Sik

Inclosed is Copy of an Order from the Committee to Capt. Stone sent by I)irections of Congress on an Application from Maryland $w^{\text {ch }}$. it is necessary you shou'd have--

I also take the Liberty to send you a List of the Field Officers \& Captains of two Regiments of Foot \& three Companies of Artillery all Provincials Station'd in Charles Town S. Carolina, shou'd you go there, upon your Arrival off the Bar

1 Among the Hopkins l'apers in the Rhode Island IIistorical cociety, is this list of the officers referred to, as follows: Christ Gadsden. Colonel of the First kegiment of foot in South Carolina; Iieutenant Colonel, lsaac Huger; Major, Charles C. l'inkney; Captains, William Cattel, Adam Mctronald, Thomas Lynch Jr., Willian Scott, John Barnwell, Thomas Pinckney. Edmund Hyrne, lioger caunders, benjamin Cattel.

SECOND REGLENT.

Colonel, William Moultrie; I,ieutenant Colonel, Isaac Motte; Major, Alexander Mclntosh; Captains. Francis Marion, Peter Horry, Daniel Ilorry, Nicholas Eveleigh, James NcInonald, Isac Ilarleston, William Mason, Francis Iluger, Charles Motte.

OFFICERS OF ARTILAERY.

Jieutenant Colonel, Owen Roberts, Esq : Major, Hon. Jarnard Elliott; Captains, Barnard Beekman, Charles Jrayton, syms White. 
the Pilot will informe vou what ()ffreer is at fort fohnson or any of the nearent Batteries to you, from whom gous may depend on all the Assistance they cain give, they are most of them Gentlemen of considerable fortunes with us who have enter'd into the service merely from P'rinciple \& to promote \& gire Credit to the Cause, they take it by Turns to be at the Fort, \& the Zeal \& Activity of all of them are such that you can't happen amiso let who will be there-

In Charles Town my particular Friencis $M^{\mathrm{r}}$. Lowndes, Mr. Fergusom, Coll l'owell. $M^{\mathrm{r}}$. Benja Elliott, Coll P'inckney, Mr. I)raytom, $\mathrm{Mr}^{\mathrm{r}}$. Timothy \& the Rerd. Mr. Tenmant a Countryman of yours will introduce you to many others, who will all be glad to have an Opportunity of obliging you \& promoting the Service.

1 wrote Yesterday to Mr. Ferguson one of the Gent" just mention'd by Way of Ceorgial. by a Centleman I can depend on who will destroy my Letter should he be taken, in this Ietter I have hinted to look out for you, \& be ready to assist you at a moment's Warning- The two large ships seen off of Virginia the $29^{\text {th }}$ of last Month we are 
told were not bound there, however you will know more certainly by the Time you get out of the Capes I make no doubt-I hope you will be able to effect that Service, but whether you may or not, sooner or later I flatter myself we shall have your Assistance at Carolina, when you may depend on an casy Conquest or at least be able to know without looss of Time when off our Bar the Strength of the Enemy, S shou'd it be too much for you prudently to encounter $w^{\text {h h }}$ I hardly think probable if soon attempted $\mathbf{w}^{\text {th }}$. the assistance to be depended on from us you may in such Cases retreat with great Ease, Safety \& Expedition-

Wishing gou every Success you can possibly wish yourself-

I am I). Sir $y^{r}$. most hble Serr.

\section{Cinist Gadsden}

P. S. Pray make my Compliments to Capt Salterstall \& the rest of your Captains, $\&$ I shall be obliged to you if you wo to Carolina to introduce them to any or all the Gentlemen I have mention'd who I am sure will be glad to show them every Civility in their Power- I hope Capt. Whipple is better- 
(one of the Maryland (ient". Mr. Mlesander a Delegate of that Colong tello me there is a very good ship of about 20 gum there easily fitted out $w^{\text {th }}$. he is in hepen will join you with the 'Homet \& Hasp' \& that he shou'd press it to be done this I mention by the by-

To Esek Hopkins Exa. Commander in Chief of the Fleet of the Lnited Colunien."

The letter to Capt. Stone of the "Hormet," alluded to in the correspondence, direeted him to coriperate with Hepkins, and. for it importance in connection with the events which subsequently accured, is here presented:

$$
\text { "Philabelpha 10" January } 17-0
$$

SIR :

We are ordered by Congrem to sig nify to you that you are with the /lomet \& 'Wasp' under your Command to take under your convoy such lessels as are ready. for the sea as shall be committed to rour Care by the Com of Safety at Maryland $\&$ see them safe through the Capes of Virginia and without a moments loss of time after

\footnotetext{
'Ilopkins l'apers. Vol. Il, i', i.
} 
this service is done you are to go to the Capes of I elaware \& proceed upwards till you join the fleet, or in case of its having sailed receive such orders as may be left for you by Esck Hopkins Esq Commander in Chief of the Fleet of the United Colonies

$\mathrm{IV}^{\text {, h }}$ orders you are to Obey

\section{Stephen Hopkixs \\ Christ GadsDen \\ Silas Deane \\ JOSEPH HEWES}

To William Stone Enq Commander of the Sloop 'Hormet' In the service of the Lnited Colonies."

The day after Hopkins' arrival, Gadsden addressed to him another letter; he was about to depart from Philadelphia on a pilot boat in response to his orders to join his regiment. This letter gives additional information as to the expected operations of the fleet. It was as follows:

SIR

$$
\text { "Philadelinia i } 5 \text { Jany i } 776
$$

I last night received my orders to go to Carolina \& expect to set out on Thursday 
morning from one of our lilut binte mon at New Castle in which I shall take my chance-Should you come our waly if wou think propere to let me know to morem or next day what signal you will show when off our bar, you may depend an my kices

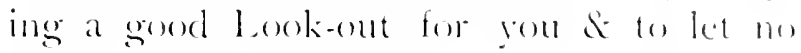
body know the signal but where it is necestiary

\section{I am Yr most hble sert

$$
\text { (HRIST (i) }
$$

In compliance with the reguent mate by Gadsden, llopkins devised a signal ly which the arrival of the fleed might be known, and informed! him that "Some one of the lileet if together or the smatl stomp if a lone will highst a striped thiges half up the flying stay." This paragraph in 1 lop). kins own handwriting is added to the original letter of Gadsdens yet preserved. It will thus be seen that it was the intention of the Naral Committee that the fleet. among other mosements, should proceed to the Carolinas and coriperate with the land forces against the enemy at that point. 
The special orders given Hopkins by the Marine Committee form an important part of the events which later occurred, and, as they must be considered in making a correct estimate of his conduct, they are here given :

"To Esek Hopkins, Esoutre,

Commander in Chief of the Flect of the Cnitid Colonies.

Sik: The United Colonies directed by principles of just and necessary preservation against the oppressive and crutel system of the British Administration whose violent and hostile proceedings by sea and land against these unoffending colonies, have rendered it an indispensible duty to God, their country and posterity to prevent by all means in their power the ravage, desolation and ruin that is intended to be fixed on North America. As a part and a most important part of defence, the Continental Congress have judged it necessary to fit out several armed rensels which they have put under your command having the strongest reliance on your virtuous attachment to the great cause of America, and that by your valour, skill and diligence, 
seconded by the officers and men under your command our unnatural enemien may meet with all posible distress on the seat. For that purpose you are instrueted with the utmost diligenee to proceed with the said fleet to sea and if the winds and weather will possibly admit of it (1) prosceed directly for Cherapeak bay in Virginia and when nearly arrived there you will send forward a small swift silings ressed to gain intelligence of the enemien situation and strength. If by such intelligence you find that they are not greatly superior to gour own you are immediately to enter the said bay search out and attack. take or destroy all the naval force of our encmies that you may find there. If you should be so fortumate as to execute this business suceessfully in Virginia you are then to proceed immediately to the soutlward and make gourself master of soch forces as the enemy may hase beth in North and South Carolina in such manner as you may think most prickent from the intelligence you shall receive: either by dividing your flect or keceping it tegether.

Having compleated your business in the Carolinas you are without delay a procecel 
northward directly to Rhode Island, and attack, take and destroy all the enemies naval force that you may find there. You are also to seize and make prize of all such transport ships and other ressels as may be found carrying supplies of any kind to or any way aiding or assisting our enemies. You will dispose of all the men you make prisoners in such manner as you may judge most safe for North America and least retard the service you are upon. If you should take any ships or other vessels that are fit to be armed and manned for the service of the United Colonies, you will make use of every method for procuring them to be thus equipped. You will also appoint proper officers for carrying this matter into execution, and to command said ships as soon as they can be made ready for the sea. For this purpose you will apply to the several assemblies, Conventions and Committees of safety and desire them in the name of the Congress to aid and assist you by every way and means in their power for the execution of this whole service.

Notwithstanding these particular orders, which it is hoped you will be able to execute, if bad winds or stormy weather, or any other unforseen accident or disaster 
disable you so to do, wou ate then to follow such courses as your best jullunent shall sugegest to goul as most useful to the American cause and to distren the enemly ly all means in your powere Jannary $5,17,6$.

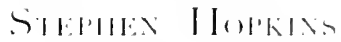

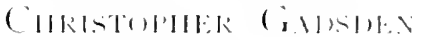

$$
\begin{aligned}
& \text { SHIN I) I.T.WE } \\
& \text { JOAEH HIEHE " }
\end{aligned}
$$

There wan another project, however, not mentioned in the orders, that hat been discusised both by Comgress and the Naval Commitlee, which was of greater impertance to the colonies at this time than the epreattions around charlestown and other peinte on the southern seaboard, and will find its place in the exents that subsecpuently tork place.

It was the intention of the Naval Committee to have the fleet sail early in January. but a severe spell of cold weather set in, the I elaware was frowen over, and obstructed the passage of the ships down the river. It was about this time that the first flase ever hoisted on an Americais ir.ur versed was flung

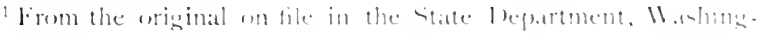
(1) 11,1 . 
to the breeze, and occurred when Esek Hopkins, the commander of the squadron, was received on board the "Alfred," his flag-ship.

Ever since Hopkins" arrival in Philadelphia he had been busily at work with the Naval Committee, arranging the details for the conduct of the expedition. At last the day came when all these arrangements were completed, and Hopkins was ready to take command of the little squadron of the United colonies.

Lying at anchor, amid the floating ice, lay the eight ressels of the new nary, their forms distinctly outlined against the winter sky.

The morning was clear and cold. Shortly before nine oclock a barge put off from the "Alfred" and was rowed to the slip at the foot of Malnut street, where, without any delay, Hopkins stepped aboard and the barge returned through the floating ice to the flagship. Crowds of people lined the whares and thore lands, while the shipping in the harbor was appropriately decorated as befit the occa-ion.

As Hopkins gained the deck Captain loudley Saltonotall gave a signal, and First lieutenant John Paul Jones hristed a yellow silk flag bearing "a lively repre-entation 


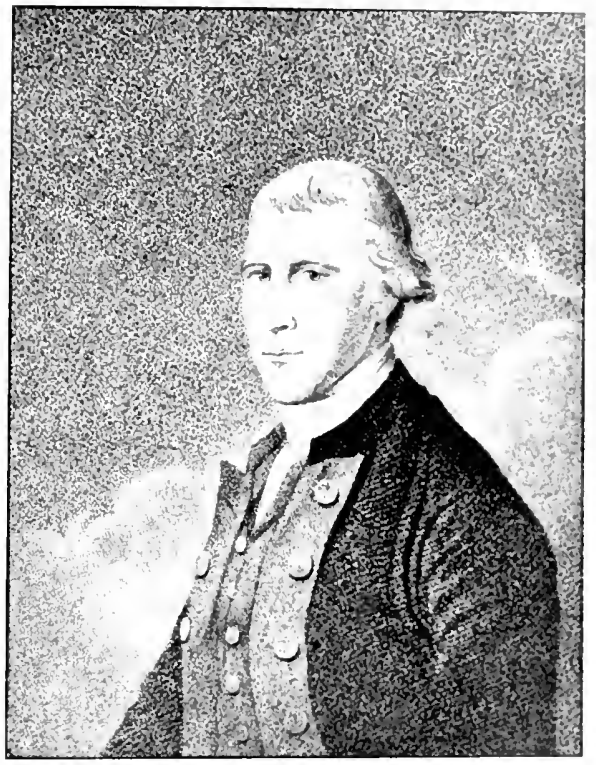

X11 $11111-1: 111111$. 

of a rattlesnake" and the motte "I hon't tread on me."

As this standard fluttered in the colde criop air the crowds along the water fromt burst inte cheers, and the guns on the shippring and the artillery ashore pealed out its salute to the flag.

With this simple ceremony the nayy of the colonies went into commission, but it was a ceremony of deeper significance to Hopkins, for with this act he had the honor of being the first who dared to unfurt the American flag in defiance of a powerful foe.

This was an event too, of such importance that Cadsden, on the eighth day of Iichruary, presented to comgress, an a memorial of the occasion, "an elegant standard such as is to be used by the commander in chice of the American Nary, being a vellow thes with a lively repreantation of a rattlenalie in the midclle in the attitude of geroing to strike and these words underneath I tont tread on me." It is mufortunate that the forst flag of the nay should not have been perecred ; th hong for some time neat the

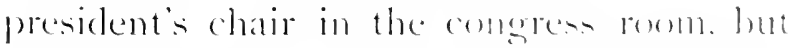
it subsecuently disappeared without leaving any trace behind. 
The cold weather continued and the ice held the ships from sailing. Late in the month, on the 27 th, Hopkins wrote to the Naral Committee:

" GentlemeN

The River holds still froze so much that the Pilots will not undertake to carry us from here Inut perhaps we may sail before the thing's can come for the small sloop by Water think it will be best to send some of the most necessary things by land such as some of the swivel guns Some musliet ball some old Canvas \& six 20 feet oars."

() 1 the tenth of February, 1776, the squadron was ready to sail, and had rendezroused at Cape Henlopen. All of the officers and men had not arrived on board the ships, and Hopkins sent from his flag-ship an imperative letter for them to "make what dispatch you can as the fleet will sail the first wind."

Hopkins now promulgated an elaborate code of signals, and issued the following orders to the captains of the ressels in his Heet :

"Orders given the several Captains in the fleet at Sailing from the Capes of Delaware Feby 1776. 
SIK

you are hereby ordereal to kerep company with me if possible, and trmly observe the signals given by the ship 1 an in-but in case you should be separated in a gale of wind or otherwine vou then are 10 use all possible means to join the liked as soon as possible. but if you cannot in four dass after rou leave the likeet, you are to make the best of your way to the Southern part of Abacco (one of the Liahama lolanels) and there wait for the leleet fourteen daybut if the fleet does not join you in that time, you are to cruise in such places as you think will mont annoy the Enemy and rou are to send into Port for Tryal, all British Vessels or property or other vennels with any supplies for the Ministerial Forces, who you may make yourself Manter of to such places as you may think best within the United Colonies.

In case you are in rery great danger of being taken you are to destroy these orders and your signals

EER HopkIX

$$
\text { comme in (hici." }
$$

1 letters and orders of the fommander in elnef. in kiknle Island llistorical society, parge 5. 
I few days later, however, the ships were manned and ready to sail, and on the serenteenth, the wind being farorable, the squadron got under weigh and sailed out on to the broad Atlantic, and before nightfall had disappeared below the horizon. 


\section{CHAPKR ル}

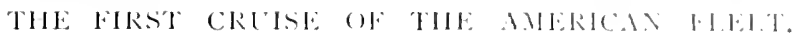

U HILE it was the intention of the Naval 1 Committee that the Heet should cruise to the southward and operate against the British ships stationed along the coast at far down as Georgia, there was ancether project in view which had been discumed by the committee as well an by congrens itself. It was a matter of so much importance that it had not been discuseded outside of the secret sersions of Congreen. and, in the Naral Committee, only behind closed doors. So well had the secret been kept that it is cloubtful if it were knomn to any one in the fleet but Hopkins, and even to this day it has never been comsidered in any account of Hopkins firet cruiec with his squadrom. In the early days of the American Revolution the sareity of powder was one of the most alaming conditions with which the autheritien had to deal. The supply from England had been 
entirely cut off, and British cruisers swept the sea, interfering with its importation. Up to this period in the history of the colonies powder mills had not become numerous, and those already erected certainly were not of a capacity to tum out a quantity and quality sufficient to meet the demands of actual warfare. At the very time preparations were being made to equip the fleet and put it in commission, Mashington wrote, "Our want of powder is inconceivable, a daily waste and no supply presents a gloomy prospect." Aready this want had been discussed by Congress and a plan for supplying it formulated. Nearly a month before, on Norember 29, information was laid before a secret session of Congress held that day, that there was " a large quantity of powder in the island of Providence," and it was forthwith "ordered that the foregoing committee take measures for securing and bringing away the said powder: and that it be an instruction to the said committee, in case they can secure said powder to have it brought into the port of Philadelphia or to some other port as near Philadelphia as can 


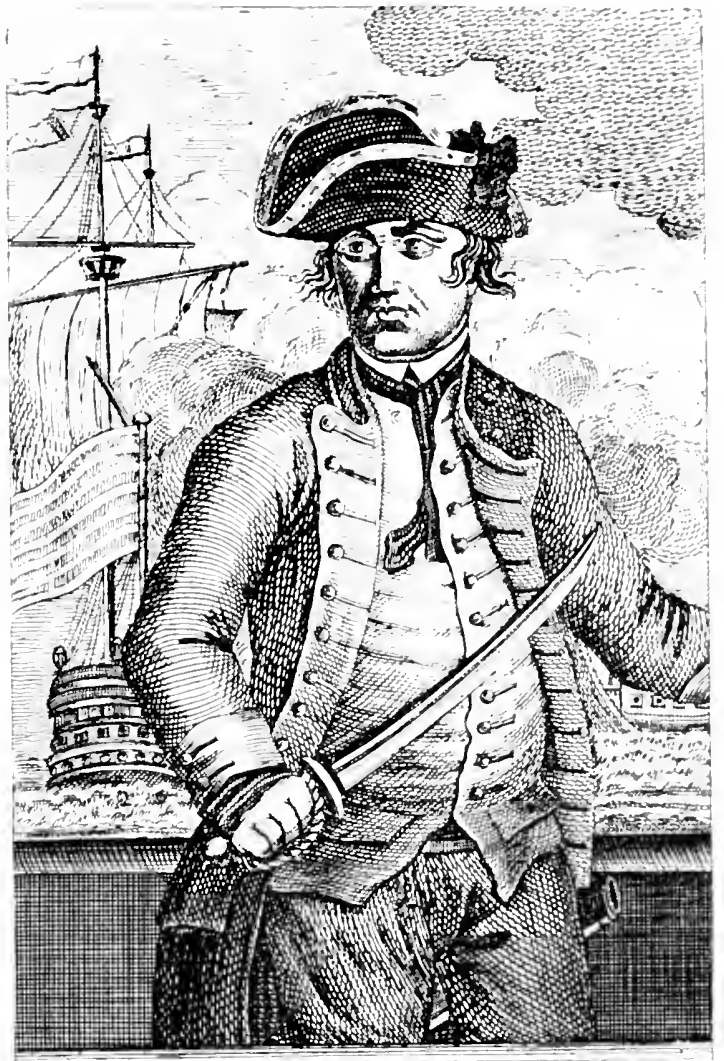

Commodore ctophins.

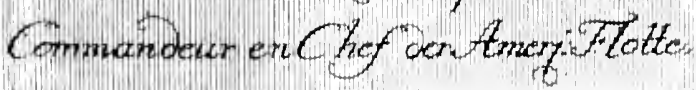



be with safety." I In the orders siren /101) kins before sailing this object is not men. tioned, but that it was part of his plan of action is evident from the orders which llopkins issued to his captains upen sailing from the Capes, wherein he directs them "tw make the best of your way to the southern part of Abaceo fone of the Bahama Intande) and there wait for the fleet fourteen day-." It would seem, therefore, from this, that two objects were in view when the fleet sailed: first, to harrass the British ships alomg the coasts of the southern and New England colonies, and second, to proceed to the island of New Providence and secure the powder and such other stores as were comtained in the forts located there. II ith these directions Hopkins sailed.

At the very outaet of the cruine the depressing influence of sickness was felt throughout the fleet, "we had many sick and four of the vessels had a large number sick with the small pos," wrote Hopkins. some weeks later. Soon after starting the wind came on "to blow hard" from the north east. The prospects of weatherings

I Secret Joumals of congrens. 
the capes in mid winter were no more promising a hundred years ago than they are to-day. Hatteras had its dangers then as now. Notwithstanding the heary gales the fleet kept well together until the second day out, when the "Hornct" and "Fly"

1 "A list of seamen and Landsmen that came out of the Capes of lelaware in the 'Fly.'

\begin{tabular}{|c|c|c|c|c|}
\hline Hoysted Hacker & $\cdot$ & . & . & Capt \\
\hline John Janning & . & $\cdot$ & . & I.ieut \\
\hline Robert Robinson & . & . & . & Master \\
\hline William Weaver & . & . & - & Steward and Cooper \\
\hline John l lowney & . & . & . & Boatswain \\
\hline Thomas liayes & . & . & . & Seaman \\
\hline Joseph Johnways & $\cdot$ & . & . & “ \\
\hline Joseph shereman & . & $\cdot$ & . & landsman \\
\hline John Young . & . & . & . & Midshipman \\
\hline William Pierce & . & . & . & Seamar \\
\hline Iolun Sorke & . & . & . & $\because$ \\
\hline Joseph lireed & . & . & . & Landsman \\
\hline Christopher Crandal & & . & . & “ \\
\hline John Cooke . & - & . & . & $\because$ \\
\hline I)aniel Gicranton & . & . & . & “ \\
\hline Iohn Clarke . & . & . & . & rooper \\
\hline Yuace Chadwick & . & . & $\cdot$ & Seaman \\
\hline Weden Carpenter & · & . & . & I átudsman \\
\hline Stephen Fowler & . & . & . & 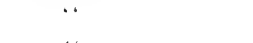 \\
\hline larker llall. & . & . & . & “ \\
\hline Samuel Tyler. & . & . & . & “" \\
\hline l'eleg Iohnson & . & . & . & Seaman \\
\hline keuben I raye & . & . & . & Lanclsman \\
\hline Ilachesan ('hase & $\cdot$ & . & . & I.anklsman \\
\hline Min Vellhoton & $\cdot$ & . & . & “. \\
\hline I awrence $\lambda$ sh & $\cdot$ & $\cdot$ & . & Seaman \\
\hline John 'hadwick & . & $\cdot$ & . & liog \\
\hline
\end{tabular}


disappeared from sight and the former did not again join the squadron.

Ilben the condition of the flect wats brought to Hopkins' attention, he decided to make his course for the bahaman into

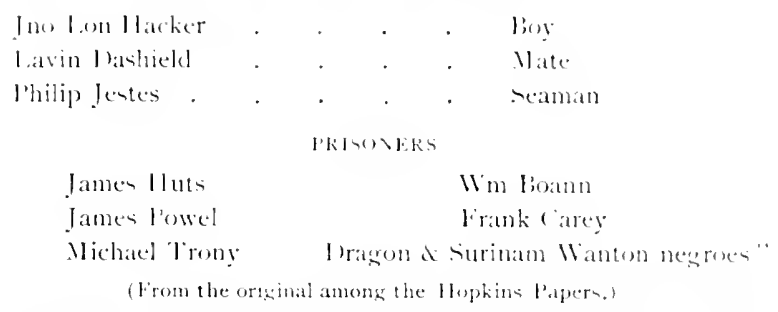

The following lint of officers on board the liteet is found amonis the Ifopkins lapers in the Rhode Intand Ilistorical saciety, and, while it has min date, it doubtless grives the personnel of the whipe at the time the ficet sailed.

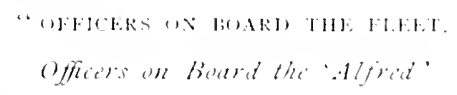

Lienj Scabury

Lieutenant

Jonathan l'itcher

(i)

Jomathan Maltbie

(1)

Jolsis Farte

Master

Thomas Vaughan

Int liale

thilip Alexander

3.1 Viale

Walter yooner

Midshipman

kobert saumlers

Charles linekley

kufus lenckes

George Ilonse

Esek Ilopkins Io

lrancis larrel

loseph llarrion

James Thomas

lin,1:-w:tin

-uricents

(itimnel 
warmer latitudes; besides this he had learned, previous to sailing, that on account of the severity of the weather the enemys ships had all sought refuge in the harbors along the seaboard, and that he must

\section{('ffices an Fourt the :A. Itoria'}

James Josiah.

Ist I. ieutenant

Elijah Marner

$2 d$ ditto

Iohn McI lourall

3 ditto

Pienjamin I bun

I aster

William Joran

Ist Mate

John I)ent

2d ditto

Iohn Marreson

$3 d$ ditto

William Keynolds

Mid-hipman

Milliam I amb

I ennis I eary

Evan Lievan

Alex Mclienzie

IIn I larby.

\section{Offucrs on biond the "Cabot'}

Elisha Il inman

Thomas Weaver

John Welch

John kierr

John sworá

Ephraim foldsmith

Alel lirisbie

J'eter Lichards

Javid Rolerts

Kich'd f'ster.

Richarel Irurdham

William Grinnel]

John kathlun
Ist I ieut

2d I ieut

(apt Marines

l.ieut

Midshipman

Ginner

loatswain

Carpenter

"Providina"

I ieutenant ditto 


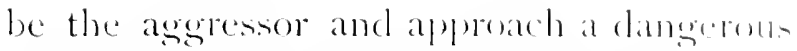
coast with little propect of gaining any ate vantage. Much had been left to his discere tion by his orders and unforeseen accibent and disasters had disabled him from the ontset; he therefore sigmaled the shipe, the course was laid for the island of . Mberen, and the lookout off Charlentown bar watched in vain for the "striped flagg half up the tlying stay." The island of Abacen is the mortherly. of the Bahama group, and lies about thirteen leagues to the northward of the inland if

IIn llopkins

sam. lirownel

John Marpeson

foseph limon

John Me Neal.

loseph llardy

foseph (Iney .

bzekiel burroughs

Iohua fanning

l)anicl liecars

kingers

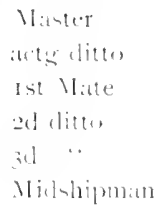

21 licitt

$3 d$

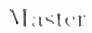

Mishlipman

IIate"

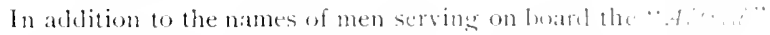
Nathaniel cooke, of cumberland, K. L., and lohn lintie, if

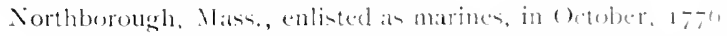

Cathaniel cooke was born in the town of cumberlamel. Ypril $1=$. I7ts. In June, 1776 , he wath chafted, and served one momth an at

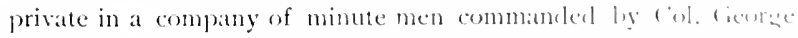
leck, and tater in the vear served a further term of one momth In October he enlisted on bourl the "figid," John l'aul Inne- 
New Providence, the objective point of the expedition. For many years this island had been a favorite point of attack. Seventy vears and more before, it had been attacked by the French and Spaniards, the fort blown up, the church and other buildings burnt, and the governor and many of the principal inhabitants carried away into captivity; this was in July, 1703. Not satisfied wtih this, however, the attacking party returned again in October and completed the destruction of the place. So completely was the island devastated that it is said "when the last of the governors appointed by the

Commander, then lying at llolmes Hole, Buzzards liay. Almost immediately afterwards the venel put to sea, cruising to the eastward. lluring this cruise she took seven prizes, one of which was the liritish ship "Wellish," bound for (zuebec, one of the richest captures of the war: for she had on board eleven thousand stand of arms and the same number of suits of clothing destinerl for the liritish army, and several brass field pieces. Ciooke served on the "Hifme" for a period of nine months, and in uctober, 175. returned to his old company commanded by col. (ieorge leck. He took part in spencer's expedition to the island of lihode latand, and in August. I7. participated in sullivan's expedition and the battle of Rhode Island.

lle served in varions parto of Rhole lsland with the militia while the liritish was in pussesion of lewport and was honorably distharged at the end of hostilities. Ile died in the town of his hinth, eppember 27 , In fo. Lor this account of his service and for the orter for prize money 1 am indebted to frank $A$. Williamson, Eerl. the great great granthon of Xathaniel cooke. 
lords proprictors, in ignorance of the Sipan-

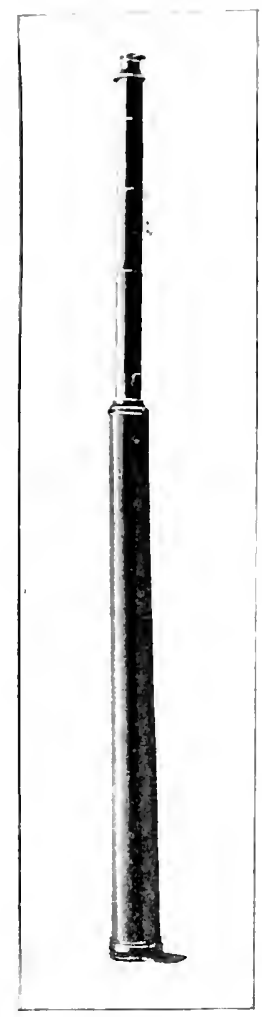

(1)

ish raid, arrived in New P'rs. idence, he foumel the island without an inhabitant." In excellent harbor, with deep) channels sufficient for rerech drawing twelve feet of water, made it a safe refuge in a locality full of coral reefo and numerous istands. I esereted and abandened as a well regeulated community, it sorm became the resort of pirater. and was a common rende\%rous for these buccancers and ocean highwaymen, "the notorious blackbeard being chief among the number."

The deperedations of these villainous crews were reported time after time to the merchante of loneton and biristol, till at last, driven derperate by their losses, they united in a petition to the crown to again take possersiom of the island and restrome order. In compliance with this petition. Captain Mooder Roseres was deputized as the first crown gorermor. 
and sailed for the island where he arrived during the year izis. Captain Rogers was a man well fitted for the position; while he cannot be classed as a pirate himself, he had sailed for years as manter of various privateers, and during the reign of Queen Anne his exploits are calculated to suggest piracy more than anything else. He was a man of great force, and accustomed to rule with denpotic sway. During one of his cruises he rescued Alexander Selkirk, a Scotchman, whom he found on the island of Juan Fernandez, where he had lived alone for four sears and four months. Captain Rogers speedily brought about a better condition of affairs. Many good families settled on the island, and it entered upon an era of prosperity. Nassau was the government seat, sitwated on the northern coast along the slope of a gentle hill facing a land locked harbor. and was protected by two forts, Fort Nassau at the west, and Fort Montague at the cast. A dangerous bar lay off the entrance to the harbor from the sea, while the two approaches by the inside courses from the eastward and the westward were amply protected by these forts.

Hopkins was thoroughly familiar with the 
neighborhood. Nearly twenty years before he had been reported at Xew P'rosideme. cleaning his vessel, and, undoubtedly, he hat sailed in and out between the island time. and time again.

The fleet arrived at . Barece on the firet of March, and on Saturday evening the seomel day of Mareh, two hundred marines, under the command of Captain Samuel Nicholas, and fifty sailors. under the command of l,ientenant Thomas Meaver, of the "Cabol." whe was well acquainted with the island, were embarked on some small resnels that had been captured. The men on board were ordered to keep below deck until the bostongen in close to the istand, it being Ilopkins in. tention that they should land instantly and take possession by an assiault from the rear. before the inhabitants could be alamerl. This, however, was rendered abortive, an the forts fired an alarm on the approach of the fleet. The boats then ran in and anchored at a small key three leagues to windward of the town of Nassau, and from thence I lopekins dispatehed the marines, with the slocp) "Prosidence" and the schooner "IV ersp" to cover their landing.

On Sunday morning, Nareh 3.756 , the 
whole force landed at the east end of the island and moved upon the smaller fort. Fort Montague, situated halfway between the place of landing and the town of Nassau. Only a slight resistance was made by the force within the fort, five guns being fired at the attacking party, but without doing any damagre. The garrison then withdrew to the larger fort, and the marines and sailors took possession of the abandoned work, where they remained and rested that night. That evening Hopkins received word that about two hundred men from the inhabitants of the town formed the only defence of the other fort, Fort Nassau. Desiring to accomplish his object without bloodshed or loss of life, Hopkins issued the following manifesto:

"To the cientlemen Freeman and Inhabitants of the Island of New Providence

The Reasons of my landing an armed force on the Island is in Order to take possession of the Powder and Warlike stores belonging to the Crown and if I am not opproed in putting my design in Execution the Persons and Property of the Inhabitants shall be safe, Neither shall they be suffered to be hurt in Case they make no resistance 
$M$
ISLAND orN
FIRSTAMERIA
SHMonde
COMMODC

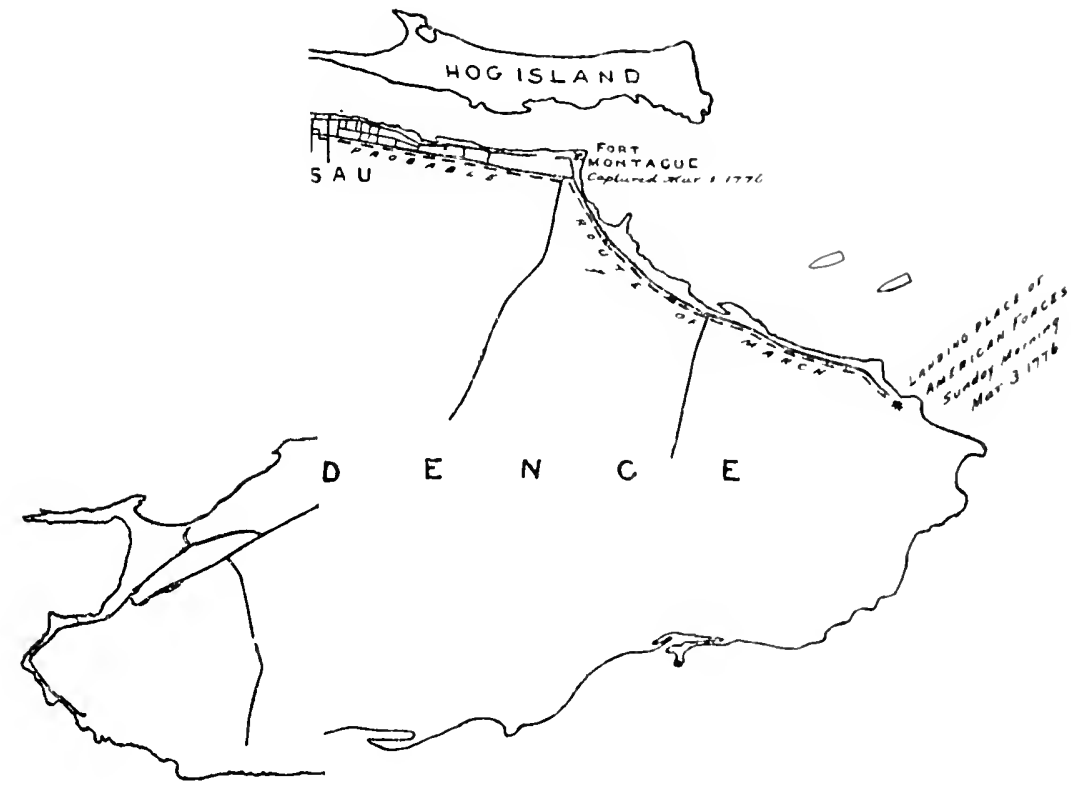




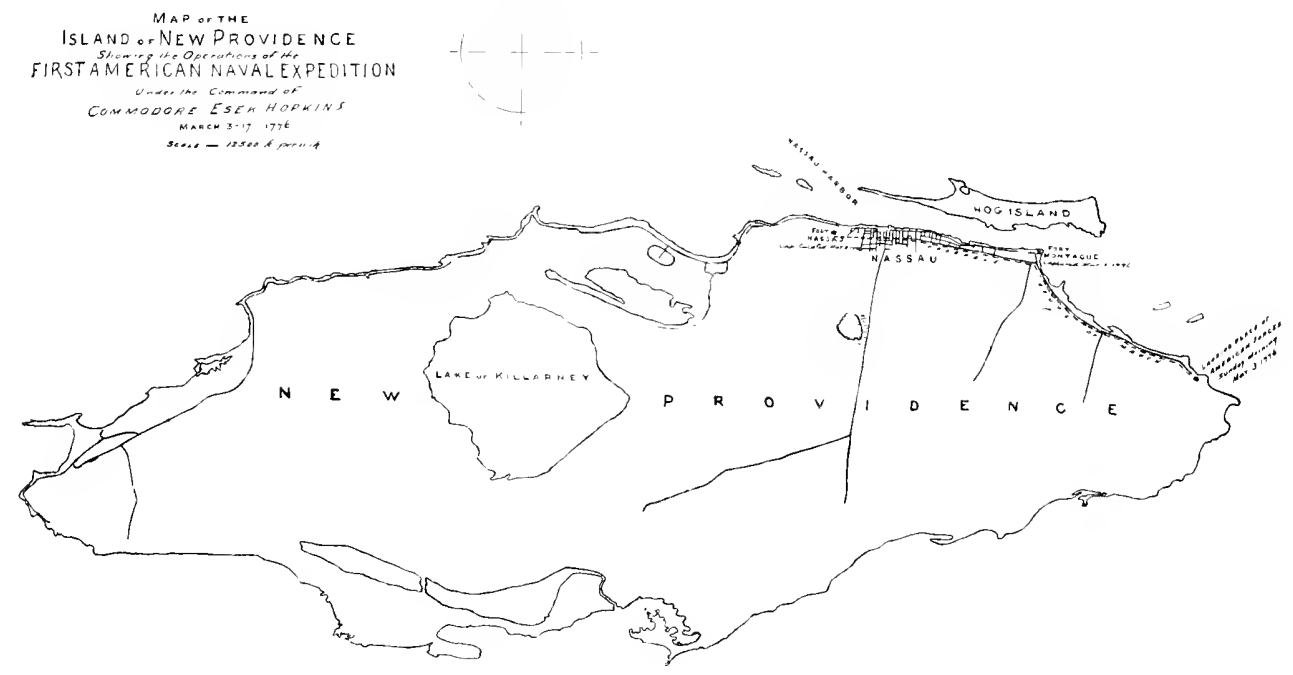


Given under my hand on board the ship Slified March 3rd $17-6$

$$
\begin{aligned}
& \text { Lak IOPRAS } \\
& \text { crin chict" }
\end{aligned}
$$

The next moming the troops marched upon Fort Nassau, but this pacific meanure had the desired effect, for a messenger ap) peared from the gorernor and told Captain Nicholas that "the western garrison (Fort Nassau) was ready for his reception and that he might march his force in as soon as he pleased." The inhabitants quietly withedew from the fort, learing the governor, Montford brown, as its only occupant. Hopkins then dispatched Captain Nicholas to the governor with an order demanding the keys to the fortress, which order was complied with, and the troops at once took postesion of the work and all of its stores."

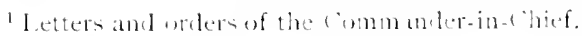

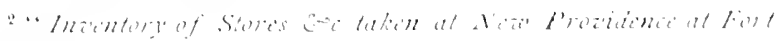
Nisinglt

$M \operatorname{arch} 317-0,1)$

7 I annon from if to 32 P'ommeter

15 . Mortars (Irass) from + tu I I inches 5337 Shells 
A rich store of munition of war rewarded the expedition. So great indeed that it was found imposible to convey it all in the ressels of the fleet, and Hopkins impressed a large sloop called the "Endearor," which he

9837 round shot \& i65 chain \& dble $11 d$ do

I to hand grenatles

8 I6 liuzees or false fires

99 - spunges Kammers a worms

to Copper ladles

407 Copper lloops \& 5 Copper Powder Measures

220 lron 'Trucks for carriages

3 liells

24 Casks lowder

$A$ quantity of match rope

2 dble blocks with brass sheaves

I scale beam

I llammer

3 Tanned lfides

2 boxes tallow candles

4 bibls flower 4 do bread + do lieef

l'art of a cask of spiritt

I sun diall \& I English flagrg

stores taken at Fort . Montasui

I7 Cannon from 9 to $3^{6}$ pounders

Narch 3,1776

I 240 Kound shott

I 2 I thells

SI Iron Trucks for Carriages

22 Copper 1 loops

2 Copper Powder Neasures

I Worm I ladle

some old lron Copper \& lead not weighed."

From the original among the llophins Papers in the Khode Island Ilistorical society. 
found in the harbor, for the purpose, promining the owners to send it back and pay for its use, which was subsecpuently dence Two weeks were oceupjed in transferring the (alptured property to the ressels, and it was mot until the seventeenth that the fleet gent wnder way for the homeward royage. In the meantime, the "F/1"," which had disappeared the second day out, mate her appearance.and her commander reported that she had "sont foul of the "lformet' and carried away the boom and head of her mast." In her dimabled condition the "Hornet" made her way" to South Carolina, where she safely arrived. When the fleet sailed Hoplins took away as prisoners of war, the governor of the inland, Montford Brown, the lieutenant-governor. and Mr. Thomas Arwin, "Counsellor and Collector of his Majesty's Quit Rents in South Carolina," and "Inspector General of his Majesty's Customs for North America." Although this expedition had been so suecensful, yet its one great object had, in at measure, failed, for the governor, aroused in his suspicions at the sight of so many formidable vessels approaching the island had. on the night before the troops landed, leaded one hundred and fifty casks of powder inte: 
a small sloop and sent her away, thus securing it against capture. Taken as a whole, howerer, the descent on New Providence was a well planned and a successful exploit.

Hopkins sailed from the Bahamas on the seventeenth' of March, and the whole fleet kept in company with the exception of the "IVasp," which soon after getting to sea parted from the other ressels.

As the fleet started upon its homeward course Hopkins isoued the following order to his captains:

"Orders given the several captains on Sailing from New Providence March is i $7 ; 6$

SIR: You are to keep company with the ship I am in if possible-but should you separate by accident you are then to make the best of your way to Block Island Channel and there to cruise in 30 fathom water south from Block Island six days in order to join the fleet. If they do not join you in that time you may cruise in such places as you think will most annoy the Enemy, or go in Port as you think fit. and acquaint me by

1.etter of John l'aul Jones to Joseph llewes. Ilopkins l'apers, vol. t, note 10 . 
the first Opporiunity so that you maly be ceive further orders

$$
\text { Ship "Alired" March } 1 \text { s 17-6" }
$$

I ientenant Elisha Himman, of the "Cabol," was put in command of the slo(e) "Indearor," which llopkins had pressed into service to assist in the removal of the stomes from the forts, and he was ordered to keep) company with the flect; in the event of his parting company, howerer, he was directed to use his "best endeavors to get into Providence" (R. 1.) "if you cant get in there," continued the order, "your are to go in the East side of Rhode Island. I Iowlands lierry under the Fort, or into New London and whenever you get into port you are to I and your guns and stores and send to ciovemor Nicholas Cooke at Providence, or (iovernor Trumbull for further orders till you hear from me." The material secured was of inestimable value to the colonies and came at a time when all such munitions were sorely needed. But the stores secured at Nassau were not the only fruits of this cruise. Nothing a curred to enliven the rogage homeward until

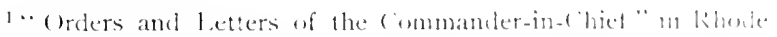
lstand llistorical sieciety. 
the fourth of April, when the squadron, then being near the east end of I.ong Island, overhauled the schooner "Hawk," of the British fleet, commanded by Lieutenant Mallace, a son of James Wallace, commanding the fleet at Newport, with whom Hopkins had already had some experience. This ressel carried six carriage guns and eight swivels, and fell an easy prey to her more formidable adversary. The next day " a Bomb brig the "Bolton' of eight guns and two howitzers ten swivels and forty eight men well found with all sorts of stores, arms, powder etc." was eaptured, all of which highly elated the commander and all the officers and men in the fleet. All this had been accomplished without the loss of a single man in action. The next morning, the sixth of April, about one oclock, the fleet fell in with His Majesty"s ship, the "Glasgow," a heavily armed resisel of twenty gums, with a complement of one hundred and fifty men. A tender abo accompanied her. By half past two, the "Cabot," Captain John B. Hopkins, had come so near that he hailed her, and upon ascertaining who she was immediately fired a broadside; and now, in the gloom of early morning, a desperate encounter took place. 


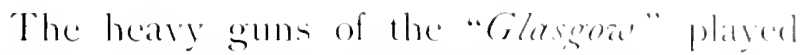
upon the "Cabol" with such effere that she was so damaged in her hull and rigging an to be obliged to retire for a time form artions; besides, her commander and seven men harl been severely wounded. and four of her werw killed outright.'

Iopkins" own ship, the "-Ifred," now ("ame into action. and for thee home the fight was most severe. While the "dlfired" was hotly engaged, the "Columber," Captain Abraham Whipple, ran under the stern of the "Glasgow" and raked her as she paned:

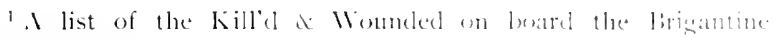
"cillot" Vizt

Athil; $1: i ;$

Kis.I.'1,

No 1 James Hoard Wilson lientenant of Marime

" 2 charles sinclair teymour Master

"3 l'atrick kaine

+ (ieorse liennedy i Marines

1111 \1111

No I John li. IJopkins lise Capt

" 2 lavid Ex:an landeman

"3 liemge liritt seaman

" + James Truwden

" 5 loumas loyle

"6 Christian ciosner Marines

" 7 John curtis

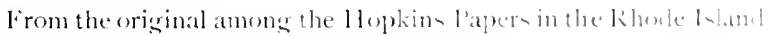
llistorical siciety. 
the "Andrea Doria" sailed into position on the larboard quarter of the "Glasgow," while the "I'roaidence," Captain Hazard, changing her course occasionally, sent shot after shot against the British ship. Thus the ships fought until day began to break, when "Captain Tyringham Howe, of the Glasgow, perceiving the force of the American fleet, seemingly increased by a large ship and a snow, which kept to windward as soon as the action began, and discerning none of Capt. Wallace's fleet to afford him the prospect of support, very prudently made all the sail he could crowd and stood in for Newport." "The bravery of Capt Howe's behavior," naturally says Gordon, an eminent English historian, "is to be commended. That he should have escaped from a force so much superior when united, does not give satisfaction to the Americans and is imputed to some failure in conduct or comrage on the side of their commanders." The losies on the American ships were not great. however, the "Cabot" sustaining the heariest loss, while one man on the "Columbus" Jost an arm.

Licutenant fohn Paul Jones thus describes the action in his entry for the day on the log book of the flag-ship : 
"At 2 A. M. cleared ship for action.

At third glass the enemy bore away, and hy crowding all sail, at length got considerable way ahead, made signals for the rest of the English fleet, at Rhode-lsland, to come to her assistance, and steered directly for the harbour. The Commodore then thought it imprudent to risk the prizes \&e., by pursuing farther; therefore, to prevent our being decoyed into their hands, at half-past six marle the signal to leave off the chase, and haul by the wind to join our prizes. The "Cobot' was disabled at the second broadside, the Captain being dangerously wounded, the Master and several men killed. The enemy's whole fire was then directed at us and an unlucky shot having carried away our whee] block and ropes, the ship broached to, and gave the enemy an opportunity to rake un with several broadsiden, before we were again in condition to steer the ship and return the fire. In the action we receiverl several shot under water, which made the ship very leaky; we had, besides, the mainmast shot through, and the upper work and rigging very considerably damaged; yet it in surprising that we lost only the second Lieutenant of Marines and four men-we 
had no more than three men dangerously, and four slightly, wounded." Hopkins, in his report of the action to the president of Congress, says: "Ile received considerable damage in our ship but the greatest was in haring our wheel rope and blocks shot away which gave the 'Glesgow' time to make sail. I did not think proper to follow as it would have brought on an action with the whole of their fleet and as I had upwards of thirty of our best seamen on board the prizes and some that were on board had got too much liquor out of the prizes, to be fit for duty, thought it most prudent to give over chase and secure our prizes and got nothing but the 'Glasgoa's' tender. *** Among the clead are Mr. Sinclair Seymour Master of the 'Cabot' a good officer, Lieutenant Wilson of the 'Cabot' and Lieutenant Fitzpatrick of the 'Alfied.' The officers all behaved well on board the 'Alfred,' but too much praise cannot be given to the officers of the 'Cabot' who gave and sustained the whole fire for some considerable time within pistol shot."

The use of liquor on ship board always annoyed Hopkins. The rules of the service permitted it to be served as a ration, and Hopkins was therefore powerless to interrupt 
its use as such. Years before thin. while in the merchant serviee, he has realised its demoralizing effect on his men, and while it was the miversal custom to serow "groge" on ship board at eleren cicherk in the forenoon and at four velock in the afternoon, the rules of the sea forecel him also to comply with the custom, yet it is said during his long life at sea and ashere "he totally abstained from the use of intoxicating liquor as a beverage."

I lopkins arried in New Lendem harbor on: the eighth of April, bringing in his entire flect. with the exception of the prize "/larke" Ile at once prepared a full report of his cruise 10 Congress and dispatched it by John Avery. Jr.. special express. On April a 6 this report was laid before Congress, where it occasioned a feeling of joyous satisfaction.

The secretary of Congress was directed to publish a part of it so that the colonice might be informed of the success of the enterprise and the worth of the new nary. John Hancock, President of Congress, an the next day sent his personal congratulations, together with certain directions of Congress, in the following letter: 


\section{"Pinlada April I 7 I 76}

SIR

Your letter of the gth of March, with the enclosure, was duly received and laid before Congress; in whose Name I beg leave to congratulate you on the Success of your Expedition. your Account of the Spirit and Bravery shown by the Men, affords them the greatest satisfaction; and encourages them to expect similar Exertions and Courage on erery future Occasion. Though it is to be regretted, that the "Glas. con' Man of Wrar made her Escape, yet as it was not thro any Misconduct, the Praise due to you and the other officers is undoubtedly the same.

I have it in charge from Congress to direct, that you send a compleat List and State of the Stores taken and brought from Providence with the sizes $\&$ c and that the Cannon and such other of the Stores as are not necessary for the Fleet be landed and left at New l.ondon.

The following extract of a letter from Antiguas, I hope will be of Service to you, with that view I send it

This is evidently an error and should be ipril. 
Axteis March 26 1750. 'The Thim 1)ivision of Transperts will leate Intigua in a few days, it is said for New lork, monder convoy of an old bant India Shipe mountings I6 guns. There will be six in Number.'

IVishing you the greatent suecens and happiness I am

\section{Sir}

Your most obed \& very hble Sere

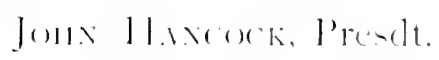

Commodore Hoplins at New l.ondom."

The news of llopkins suecens at the bahamas and his captures on the return royage, together with the bravery displayed by his fleet in the encounter with a man-ef war, was received with delight throughout the colonies.

A contemporary poet commemorated in rerse this trimmph of lopklins. Neptune in represented ats being seatly disturted by this affair while he lay

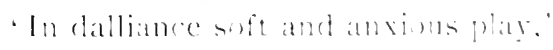

with his favorite godeless and directing the winds to go forth and make known who

Hopkine l'apers. 
dared to shake his coral throne and fill his realm with smoke.

The winds obeyed, and, having witnessed a battle,

Amazed they fly and tell their Chief

'That How is rumed past relief,

And Hopkins concuering rode.

'Hopkins:' said Neptune, "who is he That dares usurp this power at sea,

And thus insult a ciod? ?'

The Winds reply: "In distant Land

A Congress sits whose martial Bands

Defy all Britain's force,

And when their floating castles Roll

From sea to sea from Pole to Pole

Hopkins directs their course.

And when their Winged liullets fly

T'o reenstate their Liberty

Or scouge oppressive Bands,

Then Callant Hopkins, calmly Great,

'Tho' leath and Carnage round him wait

Performs their dread commands.'

The result being that Neptune, in amazement, resigns his trident and crown to Congress, and says, as

A tribute due to such renown, These Gods shall rule for me.", '

Hopkins' name was on the lips of all, and all sang his praises, but as the first burst of

1". bur French . Mllies." stone, page I I. 
enthusiasm and elation began to fade awa a change took place, and all that he hat accomplished was lost sight of when the fact was fully brought to mind that he had allowed the "Glessena" to encalpe. So intense was the fecling against him on thin account that prejudice took posten-ion of the minds of the people, and no amount of argument could brush away the feeling that he had failed at the supreme moment. From this time a dark cloud began to gather oser the head of Hopkins which was destined to gradually settle down over him and obsecure a reputation hitherto unblemished. (ap)tain I'hipple, of the "Colmbus," had been severely criticised by several of his brother officers in the fleet for his conduct in the fight with the "Glasgoa'," and, in ordere to have his acts inquired into, he demanded a court martial in a letter which he sent to Hopkins on the thirticth of April. In this letter he details, at some length, the manoeuvers of the ships on that memorable morning, and gives a more detailed account of the part he took in the fight. He says:

"I have had the Honor to serese you in the last French Wrar and to yoursatiafaction 
I thought, and since my Arrival at Philadelphia was appointed by the Congress to the Command of the Ship 'Columbus,' I have strictly obeyed your Commands and have done all in my Power for the Ifonor of the Fleet to the best of my Knowledge according to your Orders. The Night that we fell in with the 'Glesgow' Man of IVar, two of my Lieutenants was on board of the two Prizes and fourteen of the best Seamen, when we was ruming down on the ship setting in order to Engage and Quartering the Men in the places of the other that was out, the 'Glasgow' suddenly hauling to the Northward brought me to the Southward of her and brought her right into your and Capta. Hopkins IVake, I hauled up for her and made all Sail with my three Top Ciallant Sails, then Captain Hopkins beginning the Fire and the 'Glasson' returning the same and my being in her l I'ake and as far to Leeward as she it Instantly kill'd all the Wind which put it out of my Power to get up with her I strove all in my Power but in vim, before that I had got close cnough for a Close Engagement the 'Glessoa' had marle all sail for the Harbour of Newport I continued Chace under all Sail that I had 
except Steering Sails and the II ind bering before the beam she firing her lan stern Chaces inter me as fast an pereible and my kecping up a fire with my bow (imbe and now and then a broakdside put it out of my Power to get near enomsh to h we a chese Engagement. I continued this Chace white you thought propere to hosit a signal w

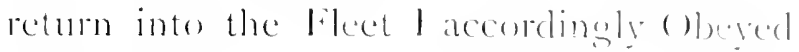
the Signal and at onr trimal at Xew london I found that the repent was from the "Ifferd" and the "Cirbot' that I wian a coward and many othere ill natured things which I say was a false report, if I flicl mot do my l luty it was not ont of Comardice but for want of Judgement, I say all the Pexple at New London look on me with Contempt. and here, like a Man not string the Cinntry in my station. Therefore I having a Family of Chideren to be uphrided with the matk of Cowardice and my own Chatre. ter now Scandalized ther the whele thire teen United Colonies. It is a thinge I cannot bear and if I ann a Cowaled I hate no business in the service of this commers. Therefore I denire that there may, hy my own Reguest a Condt Martial be allen an me, and 'Tried by my brothere ()fincers of the 
Fleet and either acquitted with Honor or Broke for I want no favour, then if I am Broke the Publick will have a right to despise me and reflect on me and my Family, If I have no satisfaction that way I will return you my Commission and thank the Congress for the Service and Curse them that made the false Report, I have never opened my Mouth to any Body concerning the matter, if your Honor had let me come to Newport when the 'Scarborough' Man of IVar lay there as I desired I would have convinced the World that I was not a Coward but now it is out of my Power.

\section{Your Humble Servant}

\section{at Command}

\section{Abraham Whipple.}

N. B. Sir, you must observe it was in the Night when we bore down upon the Glasgow', and could not see as if it had been I ay light when she altered her Course

$$
\text { A WhIPlie"' }
$$

Pursuant to his request a court martial

1 Since I made my copy of this letter from the original in the Rhode Island IIistorical Socicty, some miscreant has mutilated it by cutting out the postscript and signature. (Author.) 
was held on board the "slfred," at Prosidence, on the sistly of Mas, and he was promptly acpuitted of any miscondurt.

Captain llazard, of the "I'ros'idince" wan also the subject of a court matial for minconduct during the engagement with the "Glasgow," which resulted in his being relieved of his eommand, and I,ientenant John Paul Jones was appointed in his stead.

Upenthe arrial of the flect in New Lemelon harbor, Hopkins proceeded to dispone of the material which he had secured at the bahamas. Some of the calptured gums were left at New London, in charge of Gorernor Trumbull, a number were sent by Captain Jennings to Dartmouth, Mass., and the "Cabot" carried twenty-six to Newport to be used in the defence of the island. This action of Hopkins prosoked much criticiom from the authorities at Philadelphia, and was one of the eontributing causes of the troubles which later beset him. In a letter to John Iancock, President of the Marine Committee, he seems to have had a foreboding of impending trouble, for be says: "Inclosed you have a copy of Capt IVhipplen recpuest to me which suppose I shall grant and expect that may bring on some more 
Enquiries but do not expect anything which may now be done will mend what is past."

Soon after the fleet arrived in New London Hopkins was risited aboard his ship by General Henry Knox, who, in a letter to his wife,' makes some allusion to the personal appearance and characteristics of the commodore. In this letter he says: "I have been on board Admiral Hopkins" ship and in company with his gallant son, who was wounded in the engagement with the 'Glasgow'. The admiral is an antiquated figure. He brought to my mind Van Tromp, the famous Dutch admiral. Though antiquated in figure he is shrewd and sensible. I, whom you think not a little enthusiastic, should have taken him for an angel only he swore now and then." Brief as the description is it conveys much information regarding Hopkins' personality.

A most deplorable condition existed on board the fleet on account of sickness. The sick men were at once sent ashore and placed in temporary hospitals, seventy-two being sent from the "Alfred" thirty-four from the "Columbus," fifty-eight from the "Andra

\footnotetext{
I Irake's I.ife of knox.
} 
Doria," seventeen from the "Cirbot," siveen from the "I rosidence," and five from the "ly," a total of 202.

Hopkins secured one hundeed and seventy" men from the army, through the direction of General IVashington, to replace thene he harl landed sick, and on the twenty-fourth of . Jpril the fleet sailed from New London for Rhorke Island. On the way down the conat the "Alfred" got ashore on lisher's Inland anel had to be lightened before she could be sont off; with this delay IIopkins arrived at l'rovidence before the twenty-eighth, where he immediately proceeded to provision his ships and put them in condition for a three or four months' cruise. While thus engaged he received a peremptory order from (ienceral Washington to send the men, Who had just been assigned to the nayg, to New York. A discouraging and disheartening situation confronted him. Upon his arrival in Providence upwards of a hundred men in the fleet were found sick and unfit for duty who had to be landed, and llopkins says: "there is daily more taken down with some New Malignant fever:" Besides this, in return for the twenty-six heavy guns which he had brought to the defence of Newport. Hopkins 
expected to receive authority to enlist men from the troops there located, but almost at the same time the demand had been made for the return of the men from the army a demand had also been made that twenty of the cannon be immediately sent to Philadelphia. Under these circumstances "modesty forbade his asking for men," and he writes: "If I do I am in doubt whether it would be granted." On the twelfth of May Hopkins dispatehed the sloop "Prowidence," Captain John Paul Jones, for New York, to take back the men he had secured from the army.

Trouble soon broke out in the fleet over the neglect or inability of the authorities to pay the wages of the crews.

All the enlisted men at least had acquitted themselves with honor, and now that the cruise was over they were clamoring for their pay and naturally becoming more and more impatient as day after day went by without receiving it. This grievance of the men on the "Cabot," was made known to Hopkins by a round robin in the following words and signed by probably most of the sailors and marines: 


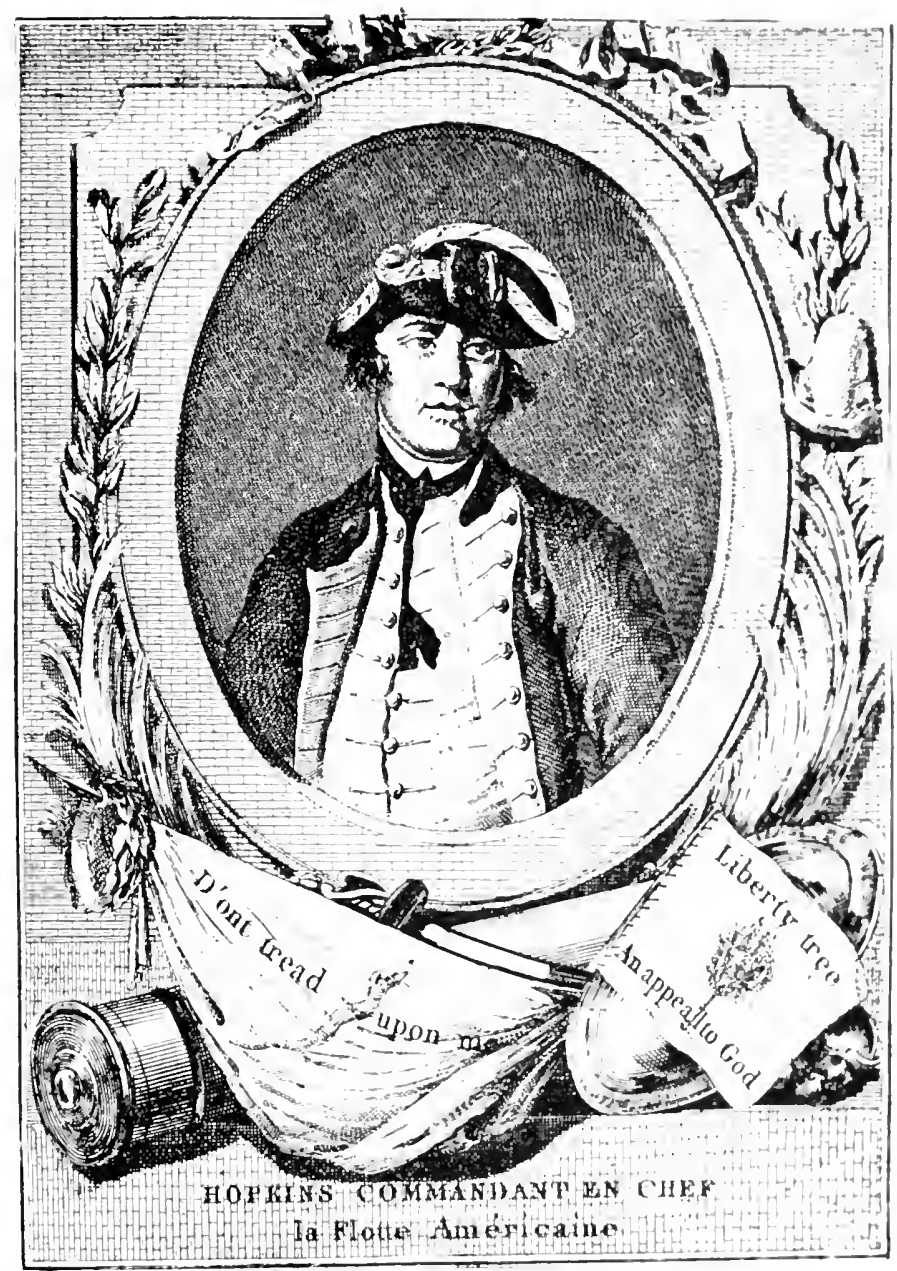





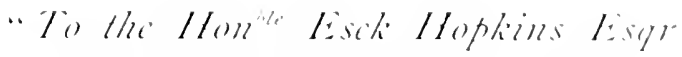

The Ilumble Petition of the Comprany of they Sailors and Marines on linated the Brigg 'Cabot' Most 11 umbly Showeth.

That your petitioners having served faithfully on board the said birge in clefence of America since her departure from l'hiladelphia: and her forst (ruise being now out They humbly hope that your $110 \mathrm{~m}^{\mathrm{r}}$ / Iecording to the usual Custom observed on lional Vessels of Mar) will adrance them some money as they are much in want of necessaries which they cannot proceed on another cruise without They humbly hope that gent. Honor will pardon this liberty and impute it to the real neeessity which they mom Labour under for the want of Cash to procure them what's necessary for their llealth \& preservation, and your petitioners as in I) uty Bound will ever Pray

Please to turn over where youll see they Subscribers Names are sed demm," and on the backside of this petition the following names were written in a circle:

"('bristian Gosner.

Thomas forbes,

William ()iboru, John Stirlin,
Phomas ciadsty,

fames llilkeson,

John linates.

inthomy omer. 
l'eter Cashinberg.

Matthew Mclee,

Andrew Magee,

James Mcsorley,

Thos I)arlys,

Michael Thirel,

Abel Jons

Robert Mills,

Iames Hall,

Joseph IVayn,

Benjamin Ford,

Richard sweeney,

Thomas Clark,

Robert Halladay,

Charles Hanet,

Jacob Pony.

Jacob Maarg.

Joseph Ravencroft,

Thomas foldthwaite,

John Harman,

John Hall.

George Mckenny,

Thomas llowd,
James fowman,

Rudolph Ecling.

Joseph Antonio,

John Roatch,

John Patrick.

Alexander Baptist.

John Little,

John King,

'Thomas Charles,

John bowles,

Nichael Thorp,

James Rusiell,

John Koung,

John Curtis,

Villiam Thompson,

Alexander Lowry,

William simall,

Thomas C'larke Senr,

Christopher Reiney,

Lewis Reding.

Robert McFarling.

Johncomnor,

We They subscribers, impatiently await your Honor's answer."

Sickness and neglect were laying the foundation for much trouble to the commander.

Only two ressels, the "Doria "and "Cabot," were sufficiently manned to go into service, and both these, on the nineteenth of May, 
sailed out of Narraganselt bay on a shomt cruise. The "Alfied" was disabled and unfit to go to sea, "she is tender sided and the most unfit ressel in the whole fleet for service and her main mast has al stl shot through it," wrote Hopkins. The "Columbus" and the other vensels were short handed by reason of sickness and the heavy drafts made to man those atready at sea. The fleet, as a whole, was therefore practically useless. The hands of the commander were tied: he had little authority; there were other causes, toos. operating against him over which he had no control and which will later appear. It was, therefore, with some discouragement that he wrote to Congress: "I am ready to follow" any Instructions that you give at all times but am very much in doubt whether it will be in my power to keep the flect together with any Credit to myself or the officers that belong to it-Neither do I believe it can be done without power to dismiss such officers as I find slack in their duty."

Before the fleet had arrived in Narragansett Bay from New London the British fleet, under Wallace, had withdrawn from Newport, and for the first time in man! 
years the waters of Rhode Island were free from British war ressels.

It was about this time that Hopkins was summoned to appear before the Marine Committee ${ }^{2}$ to answer for breach of orders. A powerful influence was working against him; whether rightfully or wrongly impelled future events will disclose; it was but the beginning, however, of a long chain of troubles and disasters which rapidly followed each other, and from which Hopkins never recovered.

1 May 14.

$\because$ It different periols the committee in charge of naval affairs was known as the Naval committee, the IIarine Committee, and the lioard of Almiralty. 


\section{CIIAPTER Y}

TIE CONGRLSIONAI. IXULIRS.

( $\mathrm{N}$ the eighth of May,, $7-6$, there was laid before Congress, presumably by the Naval Committee, the whole subject of the operations of the fleet since it had sailed from the mouth of the Delaware the previous February. It took the form, howerer. as the Journal of Congress describes it of "the instructions given by the Naval Committee to commodore Iopkins."

Ever since the arrival of the fleet at Now London, some weeks before, Hopkins had been the subject of much fault funding, and prejudice was strongly against him. The advantages gained by the seizure of so many valuable munitions of war at the Bahaman did not counteract the dissatisfaction that had been aroused by the escape of the "Glasgow'."

Already there had developed in Congrens a spirit that was destined to interrupt that harmony so essential to the success of the 
cause in which the colonies were then engaged. There was a lack of unanimity between the three factions into which the colonies naturally found themselves divided.

It produced jealousies, dereloping into political intrigues, and had a tremendous deterrent influence in every thing with which Congress had to do. Sectional prejudices were early manifested and later developed alaming conditions. "Politically the men of Virginia," says Fiske. "had thus far acted in remarkable harmony with the men of New England, but socially there was but little fellowship between them. In those days of slow travel the plantations of Virginia were much more remote from boston than they now are from London, and the generalizations which the one people used to make about the other were, if possible, cren more crude than those which Englishmen and Americans are apt to make about each other at the present day.

To the stately eleganee of the Virginia country mansion it seemed right to sneer at Xew Engiand merchants and farmers as -hoplecepers and 'peasints, while many leople in Buntom regarded Virginian planters as mere squire II enterns. 
Between the eastern and the midlle stater. too, there was much ill-will. beramed of theor logical differenees and benmelary dinputen.

The Puritan of New l Lampshire has not yet made up his quartel with the (humbman of New York conceming the ownership of the Green llomentaiss; and the wrath of the Pennstrania Quaker wased hot agamet the Puritan of Connecticut who dared clam jurisdiction orer the valley of 11 roming. 11 . shall find such animosities bearing bitter frut in personal squabbles amomg soldeliers and officers, as well as in remosals and ap pointments of offecers for reasoms which hat nothing to do with their military competence. Even in the highest ranks of the army and in Congress thene beal prejudices played their part and did no end of mi-chief." This anti New bugland feeding wan stroms even to the degree of bitternese and shemed itself in many meatures which congen wan called upoun to comsider. It affected this infant navy and all concerned with it just an it affected the army. Another influenere

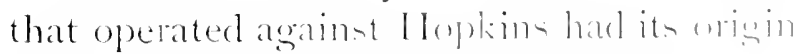
in one of the acts of comgeres which hisl 
been passed almost at the same time a nary had been projected. This was the authorized fitting out of privateers to prey upon the ships of the enemy. It cannot be charged that it was an unwise morement, for "without the succor that was procured in this manner the Revolution must have been checked at the outset," says Cooper, yet the influence which this measure produced robbed the navy of much of its effectiveness.

"The wages paid on the privateers were from one half to twice as much as Congress permitted to be paid on the Government ships which only gave a share of one third in all prizes taken and one half in the case of armed ressels while the privateers offered one half in all cases and occasionally more when there was extra hazard."

The inducements thus offered on private ships deprived the government ressels of a class of seamen most desirable. It also opened the way for abuses which were carried on to an alarming extent; for, it was not uncommon for some of these privateersmen to sell their shares before sailing. thereby realizing something before they had actually left port, and, on account of the 
greater share in which they would partice ipate, these adrancements to the men an private war vesects were correspondingly greater than to the crews of the government ships. Sometimes sailors on the gererenment resseds would receive their advancen, as was the custom, then they would ship on a privateer, discount their prospective share and desert to another section to repeat the offence.

Hopkins exerted all his encroies tomats discouraging these privateering expeditions. arousing much animosity against himself ly so doing, and so widespread had it become that he was already beginning to feel its effect.

On the thirteenth of I lecember, 1755 , the committee appointed to devise ways and means for fitting out a nary presented a report to Congress, recommending that five ships of 32 guns, five of 28 guns, and three of $2+$ guns be fitted for sea: an apprepriation was made and a committee appointed to cary out this measure.

by this resolve of Congress, two of thene ships were to be built in Rlode Island, and work was begun while fípkins was at sea with the fleet: they were ret unfinished when he returned from his cruise. 
The committee of Congress under whose directions these vessels were to be built, appointed a sub-committee to have the immediate charge of building the two Rhode Island ressels, and its members were selected from among the most prominent and influential merchants and ship owners in Proridence.

No more representative body could have been found among the men of Providence. Nicholas Cooke, the governor of the colony, a man of wealth and influence; Nicholas Brown, the leading merchant and ship owner, wealthy and of such integrity that when the town's impoverished treasury necessitated the constant borrowing of money from the citizens of the town, one who was asked to loan a small sum on a town note said "no, but I will loan it to Nicholas Brown;" Joseph Russell, of the firm of William and Joseph Russell, merchants and ship owners; Joseph Brown and John Brown, brothers of Nicholas, and business partners; Daniel Tillinghast, another merchant and ship owner, carrying on a large and successful trade with the West Indies, and later Continental agent for the state: John Innes Clarke, and his business partner, Joseph Nightingale, also merchants; Jabez Bowen, the deputy governor, a 
man of heretofore unquestioned integrity: Rufus I Iopkins, a son of (iosernor Stephen Hopkins "who had attained a high rank as a nautical commander," and all men who had served the colony in rarious important positions; these were the men against whom Hopkins was destined to be arayed in the performance of his duty.

Two ressels, named the "Itaren" and the "Prowidene," were built under the direction of this committee, the former being 132 feet long, the latter $12+$ feet.

After Hopkins returned to Rhode Island from his southem cruise, he deroted murh of his time to the work of getting thene ships. which were then well under way, ready for sea. He frequently sat with the committee and took part in the proceedings. IJe was thus in a position to be well informed an to how the work was going on.

He soon ascertained that some of the members of this committee were engaged in privateering rentures on their own account, and were using their position and influence to further their own private ends. It exasperated him greatly, and he openly accused them of malpractice. Hopkin afterwards asserted that the "two bersets on 
account of this mismanagement, cost twice as much as the contract price, owing to some of the very Committee that built the ships taking the rorkmen and the stock agreed for off to fit their privateers, and even threatening the workmen if they did not work for them."

The friendship that had heretofore existed between the Browns, with whom he had been allied years before in his political battles, and whose ressels he had commanded, was thus severed, and Hopkins at once antagonized them with all the fierceness of his nature. Such a disregard for the public weal at the very outset of a most desperate struggle was disheartening, and it touched Hopkins to the quick. Patriotism seemed to have burned out and selfish motives had quenched it.

These troubles and criminal charges "bore hard on the character of the committee as merchants and as gentlemen" as it is recorded in the committee's records, and they resented such imputations. Finally the situa. tion of affairs came to the ears of the members of the Marine Committee, under whose direction the Rhode Island committee was working, and a sharp letter was sent to the latter committee on May twenty-first, i 776, rebuking 
them for their actions. Indignantly they resented the charges, threw up the whole management of the work, and fmally turned wer the ships to stephen Iopkins, then a delectute in Congress. This affair aroused much andmosity among the parties, and only adeled fuel to the flame of discontent then burning.

These two ships when turned orer to the delegate in Congress were ready for sea but without crews.

Petty jealousies had grown up among the officers in the tleet. While some of them were Rhode loland men there were many from the other cotonies, all clamoring for official advancement, and exerting all their influence to attain it. So strong wan this that Hopkins strove to avoid becoming entangled in its attendant controversice by overlooking certain irregularities, therely weakening himself in the estimation of his friends and his opponents. It seems to have been the first evidence of a weaknes in his character. "I am very sensible that exery" officer has his friends" he wrote to his bother on June eighth, "and that has so much weight with me as not to order a Court Mantial. although ever so necessary but when the complaint came in writing and that from the 
principal officers of the fleet. I wish to God, and for the sood of my country that no officer in the fleet depended on any friend but his own merit." Abraham I'hipple had already been severely handled for his conduct with the "Glasgor," and had demanded a trial by Court Martial. Iudley Saltonstall had pursued such a course in the treatment of his men that Kenneth MacCloud, writing to Hopkins for an assignment to one of the ships, takes occasion to interject in his letter "Captain Saltonstall I will not sail with" while John Paul Jones, on June twentieth, alluded to him, in a letter, as the "ill natured and narow minded Captain Saltonstall." An insight into the spirit which perraded the officers of the fleet may be obtained by the statements in a letter sent by John Paul Jones to Joseph Hewes, for he says: "It is certainly for the interest of the service that a corclial interchange of civilities should subsist between superior and inferior officers; and therefore, it is bad policy in superiors to behave towards their inferiors, indiscriminately, as though they were of a lower species. Nen of liberal minds who have been long accustomed to command, can ill brook thus being set at naught by others, who pretend 
to claim the monopoly of sense." "That he does not refer to llopkins by this pointed criticism is crident, for in the same commmonication he writes: "I hase the pleanure of assuring you that the Commander in chief is respected through the flect, and I verily believe that the officers and men, womlen son any length to ceceute his orelers. It is with pain that I confine this plandit to an in. dividual; I should be happy in extendings it to every captain and officer in the somice. Praise is certainly due to some: but, alas. there are exceptions."

Neanwhile the remaining ships of the fleet lay in Narragansett bay, with most of their crews in the hospital. 'Two new shipe ready for service swang idly in the stream. with no immediate prospects of crews to man them. Insubordination among the officers was rampant, and this important brandh of the service, at a time when it was most in demand, remained practically worthlen.

For some weeks after the "instructions" had been laid before Comeress the matter was the subject of consideration, and it wan not until the thirteenth of jume that action was taken to investigate the subject, when Congress ordered llopkins and (aptains 
Saltonstall and Whipple to repair to Phitadelphia to be tried for breach of orders. On the next day John Hancock, President of Congress, addressed a letter to Hopkins, wherein he says:

"SIR: Notwithstanding the repeated efforts and solicitations of the Marine Board to put the Continental ships upon a respectable footing, and to have them employed in the service for which they were originally designed, they are constrained to say that their efforts and solicitations have been frustrated and neglected in a manner unaccountable to them; and in support of their own reputation, they have been under the necessity of representing the state of their Nay to Congress, and have informed them that there has been great neglect in the execution of their orders; and that many and daily complaints are exhibited to them against some of the officers of the ships and that great numbers of officers and men have left the ships in consequence of ill usage, and have applied to the Marine Board for redress. These, with many other circumstances, have induced the Congress to direct you to repair to this city *** As your conduct in many instances requires explanation you will of 
course be questioned with respect to your whole proceedings since you left the cits." Similar letters were also sent to Captains Saltonstall and Whipple: General Mashington was also apprized of the summons to the three officers of the fleet.

In response to this summons llopkin and his two captains repaired to Philatel. phia. During the absence of llopkins the command devolved upen Captain Nicholas biddle, the ranking captain in the fleet. This officer was without any authority save on his own ship, and what confusion and insubordination existed previously was intensified by the departure of the commander and the two captains. It was not until September that Iopkins returned. On the eleventh of July, Saltonstall and IIhip)ple, upon recommendation of the Marine Committee (the new name for the Naval Committee), were exonerated by Congren. Whipple being gently admonished "to cultivate harmony with his officers." The trial of Hopkins, however, was not so soon disposed of, and it was not until Augunt twelth that he appeared before Congress. To a friend, about this time, he wrote: "I am glad that I am to be tryed by a court that I 
can have no cloubt but will judge from matters of fact and not from any rumors propagrated out doors without the least foundation."

He certainly expected that he would receive fair treatment in the consicleration of his case, and that sectional prejudices and political differences would not be made the basis of the judgment of his superiors.

Hopkins appeared before Congress, and on the twelfth of August, "the examination taken before the Marine Committee," and the report of the Committee were read to him, after which he addressed the delegates in Congress, giving his reasons for pursuing the course he had, and produced two witnesses to substantiate his statements; then he withdrew from the hall.

The main points of Hopkins' defence are outlined in a letter to his brother, written a few days before he was summoned to Philadelphia for trial. In this he says:

"When I went to the Southward, I intended to go from New Providence to Guorgia, had I not received intelligence, three or four days before I sailed, that a frigate of twenty-eight guns had arrived there, which made the force, in my opinion, too strong for us. At Virginia they were likewise too 
strong. In Delaware and New York it would not do to attempt. Rherde Island. I was sensible, was stronger than we, but the foree there was nearer equal than anrwhere else, which was the reasem of my attemptthere, which answered no other end than the British force quitting the Govermment.

When l attempted the fleet at Rhorle Island, had all the commanders behared an well as I expected they would. I should have had it in my power long before this to have relieved most of the Southern (iovernments from their present difficultics; but as the case was, it was lucky we did not fall in with the whole strength at first. I was not deceived in the strength of the enemy, but greatly in our own resolution; perhaps I was wrong in not giving my sentiments fully at first, the reason of which was, I was in hopes then of some further action, and that we might retrieve the character of the fleet. But the inattention to business of most of the officers, and an expectation of getting higher stations in the new ships, has, as I think, been some hindrance to getting the fleet ready to sail so soom as otherwise it might. I had no apprehension of the cannon being wanted more anywhere else, which 
was the reason of my delivering them to Governours Cooke and Trumbull.

The very great sickness which then was, and still is, amongst the seamen of the fleet, rendered it impossible to undertake any enterprise for the relief of any colony, although in ever so much distress. All that I have been able to do was, to send the two brigs on a cruise, which I acquainted them (the Naral (ommittee) with."

He also prepared a brief memorandum of his answer to the report of the committee " that I did during my cruise southward not pay due regard to the tenor of his instructions," which was thus expressed:

"My orders was maid the 5 day of January and I did not sail till the 17 th of February which altered the station of the Enemy perticulior as to the strength of the fleet at Virginia and all the ministerial ships lieing North and South Carolina as appears by Letters from the Naval Committee as also it appears to me they I)id not expect I should strictly follow the order But my own judginent and prudence according to the last Article in my orders,"

${ }^{1}$ llopkins Papers, vol. th note 26. 
The report of the Committee and Hopkins answer to the charges against him then came up for consideration, and his conduct and official acts were fully discussed. John Aclams stood up manfully for his defence; he recognized IOpkins limitations and frankly admitted them: he realized, too, that other influences besides the conduet of Hopkins were working powerfully among his fellow members in Congress.

besides this: Idams had been from the start much interested in the building of a navy, and the result of its first expedition had filled him with a pardonable pride. Writing to a friend soon after Hopkins arrived from the Bahamas. he said: "You will see an aceount of the fleet in some of the papers l have sent you. I give you joy of the Admiral's suceesis. I have vanity enough to take to myself a share in the merit of the American Nayg. It was always a measure that my heart was much engaged in, and I pursued it for a long time against the wind and tide, but at lant obtained it." " He therefore entered into the defence of Hoplins with a determination that justice should be done him if it lay in his power to accomplish it.

\footnotetext{
1 llopkins lapers, vol. 4, note 9.
} 
Ender the date of August twelfth, 1776. John Adams afterwards wrote: "Commodore Hopkins had his hearing; On this occasion I had a very laborious task against all the prejudices of the gentlemen from the Southern and Niddle States and of many from New England. I thought, however, that Hopkins had done great service, and made an important beginning of naral operations.

It appeared to me that the Commodore was pursued and persecuted by that anti New England spirit which haunted Congress in many other of their proceedings, as well as in this case and that of General Wronster. I saw nothing in the conduct of Hopkins, which indicated corruption or want of integrity. Experience and skill might have been deficient in several particulars; but where could we find greater experience or skill? I knew of none to be found. The other captains had not so much, and it was aftewards found they had not more succeris.

I therefore entered into a full and candid investigation of the whole subject; considered all the charges and all the evidence, as well as his answers and proofs; and exerted all the talents and eloquence I had in 
justifying him where he was justiflable and excusing him where he was excusable."

After the trial hat conded Milliam Ellergy. a member from Khode Istand, the suecenos of Samued Ward, who had died in Philated. phia while Congerse was in sersion, came over to Idams and said: "You have made. the old man your friend for life: he will hear of your defense of him and he never forgets a kinduess."

Such proved to be the case for many years afterwasds Iopkins visited his friend and defender under most distrensing cireumstances, to show his sratitude for the interest Adams had taken in his behalf.

Congress held the matter under advinement until the sisteenth day of lugunt, and on that day passed the following renolution:

"Resolved, that the sild conduet of Commodore Hopkins deserves the censure of this house and this house does aceordingly censure him." On the day following the passage of the rote of eensure ! lopkins addressed a letter to the President of (inngress acknowledging the receipt of the coply of the resolve and stating that be would remain in Philadelphia "to know if they hate any further commands." On the nineteenth 
Congress directed him "to repair to Rhode Island and take command of the fleet formerly put under his care."

Hopkins returned from Philadelphia feeling keenly the strictures of Congress; a reputation heretofore unsullied had been attacked, and the representatives of that country he had used his best endeavors to defend, adrance and protect, and in whose interest he had staked his life, had smirched it.

Notwithstanding the great pressure that was brought in Congress to dispose of him entirely, John Adams felt that Hopkins had accomplished much and was entitled to better treatment, and he exerted himself to save him from the disgrace of a discharge, and it is certain that without his efforts Hopkins would have then been dismissed from the service. Of the result Adams wrote:

"Although this resolution of censure was not in my opinion demanded by justice and consequently was inconsistent with good policy, as it tended to discourage an officer, and diminish his authority, by tarnishing his reputation, yet as it went not so far as to cashier him. which had been the object intended by the spirit that dictated the 
prosecution, I had the satisfaction to think that I had not labored wholly in vain in his defense."

Additional information on this suljject is derived from the following words of fohn Adams, written some months before the trial of llopkins occurred:

"There were three persoms at this time who were standing subjects of altereation in Congress, Gen. Wonster, Commodone I lop)kins and a Mr Wrixon. I never could discover any reason for the bitterness against Wooster, but his being a New England man; nor for that against Hopkins but that he had done too much; nor for that against Vrixon, but his being patronized by $.1 / y^{\circ}$ Samuel Adams and Mr R. II. Lee. Be it as it may, these three consumed an immense quantity of time and kept up the passions of the parties to a great height."

John Paul Jones was at sea in the "I'roe'idence" when be learned the result of $\mathrm{H}(\mathrm{p})-$ kins' trial. This news he doubtless obtained from some ship master who had not been thoroughly informed in the matter. Ile may however have felt that the result was lese harsh than had been anticipated. At any rate, from the "I rosidence" in "N I atitude 
$37^{\circ}+0^{\prime \prime}$ and IV. Long. 54," on September 4 , he sent a letter to Hopkins by the brig "Sea Nymph," Capt. W'. Hopkins, saying: “I know you will not suspect me of flattery when I affirm that I have not experienced a more sincere pleasure for a long time past than the account I have had of your having gained your cause at Philadelphia in spite of party. Your late trouble will tend to your future advantage by pointing out your friends and enemies. You will thereby be enabled to retain the one part while you guard against the other You will be thrice welcome to your native land, and to your nearest concerns. After your late shock, they will see you as gold from the fire, of more worth and value; and slander will learn to keep silence when Admiral Hopkins is mentioned."

On the twenty-second of August the Marine Committee ordered Hopkins to dispatch four of the rensels to cruise in the neighborhood of Newfoundland, to destroy the fisheries and to intercept British merchantmen bound for the Gulf of St. Lawrence. At the same time he was authorized to purchase the "Hawl," one of the ressels captured by him on his way from the Bahamas, fit it 
up and rename it the "/loptins," and semel this vessed with the others to Newfoundland, and to "hoist his broad pennant on board any of the ressels." such a properition seems to imply that already the committee were somewhat ashamed of the way they had used him, and sought to atone for it by offering this honor of maming the vesuct an a sop to his wounded feelings, for as Jurlege Staples well says, "Such a compliment is seldom paid to an inefficient or unfaithful officer:" (On account of the lack of seamen the ships were not sent on this experlition, "there are so many privateers fitting ont which gives more encouragenent to shares it makes it difficult to man the continental vessels," wrote llopkins. The failure of this expedition to Newfoundland prosoled much criticism from the Committee, and on the tenth of Oetober, the Marinc Committee addressed Hopkins this letter, wherein he was ordered upon another cruise:

"Sir" :

We learned some time since with much concern that the expedition we had planned for you to execute would prose alontive as the shijs had gone out a cruizing under the Struction of Governor Trumbull. 
recommendations, with which we cannot be well satisfied, altho, in this instance, we are disposed to pass it by in silence, being well convinced both he and the several Captains meant to perform Serrice at a time when the Ships were idle.

Supposing, therefore, that you will have been obliged to lay onside the expedition to Newfoundland. We now direct, that you immediately collect the "Alfred," "Columbus," "Cabbot" and "Hampiten," take them under your command and proceed for Cape Fear in North Carolina where you will find the following Ships of IVar

$$
\begin{aligned}
& \text { The 'Falcon' of I } 8 \text { Guns } \\
& \text { 'Scorpion' of I } 6 \text { Guns } \\
& \& \text { 'Crmiser' of } 8 \text { Guns }
\end{aligned}
$$

and a number of valuable prizes said to be to in number and other vessels under their protection, the whole of which you will make prize of with ease. IVe understand they have erected a kind of a Fort on Bald Head, at the entrance of Cape Fear river, but it being only manned with a few people from the Ships we expect you will easily reduce it and put the same in the possession of the State of No. Carolina or I Dismantle it as may appear best. When you have performed 
this service you had best deliver to the Cintimental Agent there such of your prizen an may sell well or be useful in North Carolina others you mey comey inte Virginia or this place for we dont recommend your remaining in North Carolina for fear of being blocked up there. Perhaps you moreceive advice that will render it eligible to proceed further southward to Rout the Enemice Ship at South Carolina \& Georgia and if that is practicable you have not only our approbation but our orders for the attempt.

We hope sir you will not loose one single moment after the receipt of this letter but proceed instantly on this expedition.

IVe are sir

Your humble Serrants

RORT МORRIS

MIJIAM EMLER

JosMAH BARTLETT

Tin) II KenN

RICHARD HENRY LAR:

Wh ITOOPRK

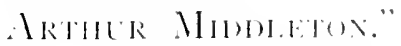

This letter arrived during llopkino absence and was delivered to his som. (a)pt.

\footnotetext{
IIophins Papers, vol. 4. mote: $=2$.
} 
John B. Hopkins, who had been wounded in the encounter with the "Glasgow" but was again on duty. He recognized its importance and at once dispatched it by special messenger to his father. He adds, in a memorandum wherein he excuses himself for opening the letter, that "our ship is all ready but manning." For the same causes this expedition also failed, and, so far as it is possible to now judge, the commander was powerless to act. The apparent disregard of these orders by Hopkins only intensified whatever prejudices had been aroused against him in Congress. Changes were being constantly made in the personnel of the Marine Committee. and this committee was the subject of severe criticism for its inactivity. John Jay, on October I I, the day after the order of the Marine Committee was sent to Hopkins, wote to Edward Rutledge: "What is your fleet and noble admiral doing? What meekness of wisdom, and what tender-hearted charity! I can't think of it with patience. Nothing but more than ladylike delicacy could have prevailed on your august body to secrete the sentence they passed upon that pretty genius. I reprobate such mincing, 


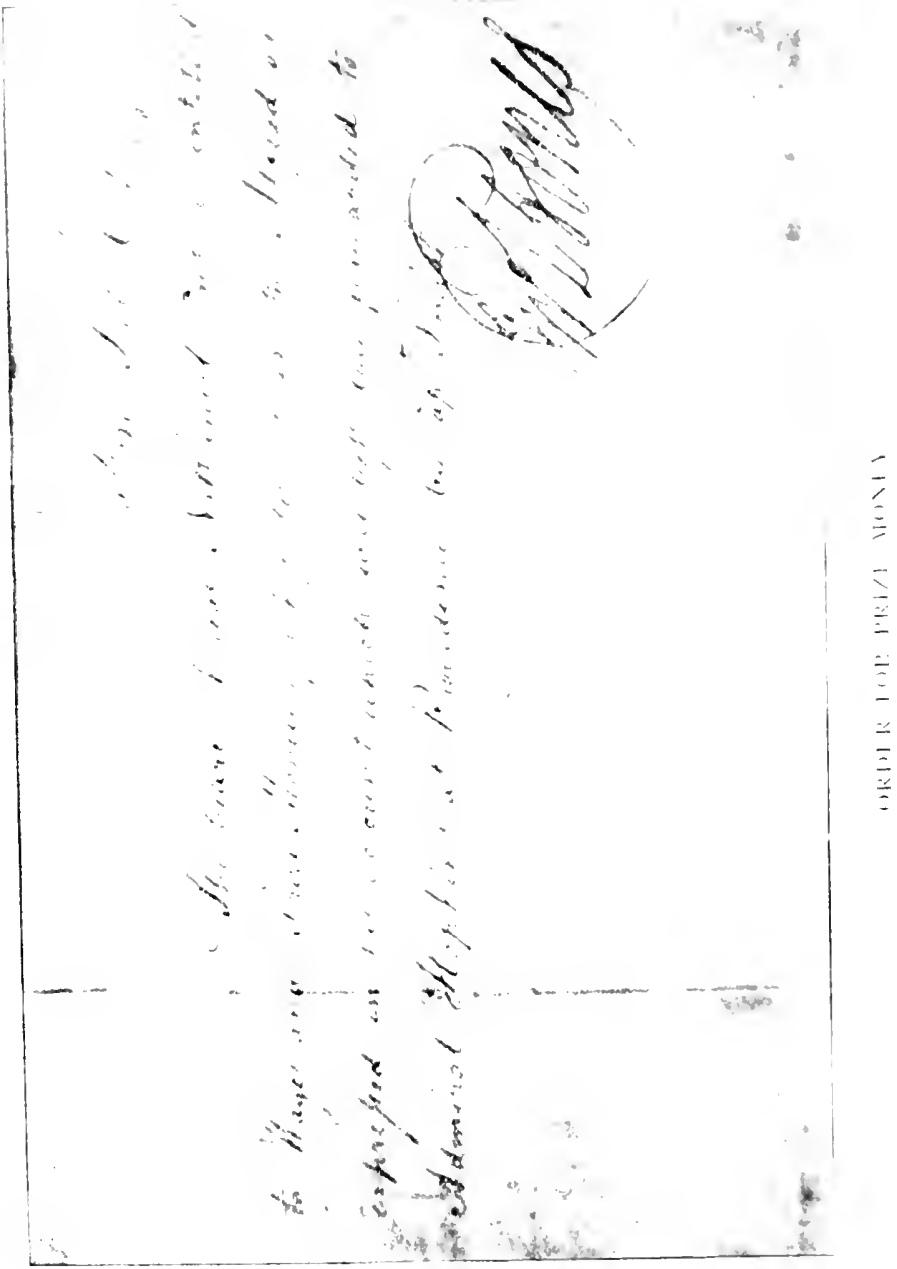



little zigzage ways of doing busines. Either openly acquit or openly condemn," and this illustrates the general trend of public sentitiment regarding this branch of the service.

lopkins endearored to put this order of the committee into execution, and exerterl all his influence and energies to this end, and a few days later he appeared before the (ieneral Assembly of Rhode Island, then in sersion at Kingatown, "and applied for an embargen till the Continental fleet was manned." He worked diligently with the members to secure the passage of this act, "but failed in getting it by two votes, owing to a number of the members being deeply concerned in privateering." In despair he wrote to the Marine Committee: "I thought I had anme influence in the state I have lived in solong but find now that Private Interent beases more sway than I wish it did," and he adels: "I am at a loss how we shall get the shipe manned as I think near one thired of the men which have been shipd and reed their monthly pay have been one way or another carried away in the privateces I wish I had your orders when Ever I found any man on board the privateers giving me leave not only to take him out But all the rest of the 
men; that might make them more Careful of taking the men out of the service of the State."

This power, however, was denied him. but on October twenty-sixth Congress did provide that "privateers could only fly pennants by permission of Continental Commanders," and such private vessels of war were required to show due respect to continental vessels on penalty of loss of commission.

Thus time dragged on, little being accomplished by the fleet, and the spirit of dissatisfaction with the commander growing stronger and stronger, until the early days of l necember. One disaster after another had occurred to cast odium upon the little American Nary, and it seemed as though the fates had conspired against it and all connected therewith, when, on the seventh day of I necember, 1776, a British fleet consisting of "about fifty four sail of transports and sixteen sail of men of war," sailed into Narragansett bay around the north end of Conanicut island into the harbor of Newport. On the next day a force of six thousand men landed and took possession of the town. The news was hurriedly sent throughout the colony, and excitement ran high. 
With the British fleet and trospen holding Newport and the adjacent territory: the Imerican fleet was as completely bleskiaterl within the waters of Narragannett liay an was the fleet of Spain at Santiag".

On December tenth, Ilopkins, from his flag ship, the "Ifarron," then lying fire miles below Providence, sent a dinpated to the Marine Committee explaining the situation in Rhode Island, wherein he salls:

"Three days ago the English Heet, of about fifty-four sail of transports and sisteren sail men of war arrived in the bay and two days ago they landed, I believe, about foro troops, and took possession of the island of Rhode Island, without opposition. The inhabitants of the town of Newport fasoned their operation, I believe, too much. The Militia are come in, in order to prevent the further operations. I thought it bent to come up the river after the fleet was within abrut two leages of us, with the "II arren" "I' rontidence," "Columbus" brigantine "/lampaten." and sloop "Providence." The inhabitantsare in daily expectation of an attark on the tomm of Providence. I have got the ships in the best position of defence we can make them. without they were fully manned. which they 
are not more than half. Wre lay where the ships cant come up that draw much more water than we do. If we get the ships manned, shall take some favourable opportunity and attempt getting to sea with some of the ships; but at present think we are of more service here than at sea without we were manned." The situation in Rhode Island at this time was a most alarming one. All of the state troops were called into service, the fortifications which had been thrown up all along the bay side were hurriedly man. ned, and the whole state became a vast camp confronting the enemy. For nearly three years the British remained in possession of the town of Newport and the adjacent territory. During this time, conflicts between the two contending forces were frequent.

It was not long after the British forces took possession of Newport that an incident occurred which brought down upon Hopkins much criticism from the officers of his fleet, as well as from the people in the state.

Whether he was justly so criticised is difficult now to decide, yet the incident was used against him with telling force in the events which subsequently took place before 
Congress, and was brought up again in a suit at law which followed.

()n the seeond day of January, 175\%, at about one oclock in the afternoom, white the "Harron" was lying off Field's Point, at the entrance to Providence harbors an orderly from Colonel bowen, whe wan located at IVarwick, came on board and delivered to Ilopkins a messige comtaning the information that a British war venesel was aground near llawwick Neck, about half way between Providence and Newport. At this point there had been erected a battery of two eighteen pound gums and a permanent garrison established.

I'hen the news was received, the ship) "Prozidence" lay about a mile below the point, and the sloop "Providene" lay against the Pawtuxet shore, about four milen still farther to the southward. As soon an Ilepekins received this information, he endearored to get down the river to insentigate the situation. Captain Allen Brown, a pilet, was at that time on boned the "If armo" lle in described as "one of the best in the rivere" who, being consulted as to the advinability of taking one of the ships down to the peint where the grounded ressel lay, informed 
Hopkins "the wind was so far westerly and - blowed so hard that the ships could not be carried down."

Between Field's Point and Warwick Neck there was then, and there is now, a reach of circuitous channel "narrow and crooked." It was within this reach that years before the "Gaspee" had met her fate after grounding in its dangerous shoals. Hopkins therefore did not venture with either of the ships, but, taking the "Warrn's" pinnace with twentytwo men, went to the "Proaddnce" (sloop), Captain Whipple, taking Captain Brown, the pilot, with him. Lpon arriving on board the sloop and finding her fully manned, they immediately got under weigh and proceeded down the river toward the stranded vessel. As the sloop drew down upon her it was discovered that she was the Frigate "Diamond," and that she lay "on a shoal which runs off $S$. IV. from Patience about half a mile from that Island and a little more S. E. from Warwick Neck." There was about eleven feet of water at low tide, and as the tide was about half down she did not careen. Lying about a mile and a half off, about southwest by south, was a fifty gun ship with her top sails loose, her "anchor apeak," which, 
as the wind was, could have floated here within pistol shot of the "/lirmond."

Hopkins was of the opinion that on arcount of the severity of the wind she did not "come to sail." From his knowledge of the river and bay, with the gate then blowing. he felt that it would be unwise to oreter his ships down to the "Iirmond," and even if the wind had not blown so hard and the ships could have been brought down. he afterward said he should not have done so, for "the Enemy's ships could have come to sail with any wind that we could and a great deal better as they lay in a wide channet and we in a very narrow and very crooked one." Arriving off Marwick Neck, Hopkins went ashore to the fort, where he was informed by Colonel Bowen that he had sent for two eighteen pounders, and, after remaining there a half hour, until the guns arrived. Hopkins went back to the stoop.

What subsequently took place is bent told in Hopkins' own words :

"I went aboard the sloop and we dropper down under the ships stern a little more than at musket Shot off it being then a little after sunset. we fired from the sloop a number of whor which she returned from her stern chaners: 
the ship careened at Dusk about as much as she would have done had she been under sail, after they had fired from the shore about twenty six shots they ceased and soon after hailed the sloop and said they wanted to speak with me. I went ashore and was informed they were out of Ammunition. I offered them powder and stuff for wads but we had no shot that would do, they sent to Providence for powder and shot and I went aboard the sloop and sent some junk ashore for wads, soon after they hailed again from the shore and I went to see what they wanted, and gave Capt. Whipple orders not to fire much more as I thought it would do but little execution it being night and could not take good aim with the guns. When I got ashore the officer that commanded them desired that I would let them have some bread out of the sloop which I sent the boat off for but the people not making the boat well fast while they were getting the bread she drifted away and I could not get aboard again. The ship by lighting got off about 2 oclock the same night."

Hopkins did not regard this exploit with much concern until nearly two months afterwards, when he found that a "scandalous 
account" of the affair had been sent to the Marine Committee by a Mr. Verey, ome of the prize agents at boston. It so happenes that this Mr. Vesey, while on his wat from Philadelphia to boston, stopped at Providence to consult with lopkins, and when the news that the frigate was anhore reached the "IFrren" he was on beard. Desiring to participate in the adrenture he "went down as a volunteer with the commodore on the sloop "rovidene," and thus became an eye witness to all that occurred. In his account be says: "she (the 'Plamond") wan suffered to depart though the wind was directly down the river so that nome of the English ships could come to her assistance."

This story of lesey was repeated from one to another and finally became a subject of such impertance that it entered laresely. into the causes which finally led to llopkins diseharge from the mary.

The officers in the flect inimical io 1 lopkins macke light of it. the peeple of the state, who were in no position to know the merits or demerits of the case, momelly rensured him for letting a hejplen British frigate escape. It served alos to bring back again to the minds of all the unfortumate aftair of 
the "Glasgow," while many a smile was produced at the ludicrous position of the commander of the navy rowing backward and forward from his temporary flag-ship at the whim of a military officer at a bay side battery, until he lost his boat and was unable to gain his ship.

Troubles which were growing greater and greater seemed following closely after Hopkins.

During the early part of the winter the "Alfred" and "Cabot" got to sea and succeeded in getting around to Boston. from which place they cruised independently. About this time Hopkins wrote to IVilliam Ellery, then a delegate in Congress from Rhode Island: "We are now blocked up by the enemys fleet the officers and men are uneasy, howerer I shall not desert the cause but I wish with all my heart the Hon Marine board could and would get a man in my room that would do the Country more good than it is in my power to do, for I entered the service for its good and have no desire to keep in it to the disadvantage of the cause I am in."

This uneasy, inactive life of the officers in the fleet, was productive of no good to any 
one. Bickerings and contentions oxemed between themselves, while it also afforked a farorable opportunity for the completion of a well laid plot to get rid of their commander. It would be unfair to aceuse all the officers of the fleet of being partic to this transaction; there were many who were loyal friends of the commander, but anomg the officers of the "Il arren," Ilopkins own ship, he seems to have had few whom he could call such.

These erents practically close Hopkins career in the naval scrvice of the Lnited States. The flect never again got to sea, and, although individual ships performed most valuable and important service, and the offeces won imperishable remown for bravery and heroic conduct, the naval squadron, which sailed so proudly on its course from Delaware bay nearly a year before, practically ended its life in Narragansett bay:'

What ultinately became of all the veneth of the firs . Imeritan Heet is uncertain. So record has been preacervel of the fite wi the

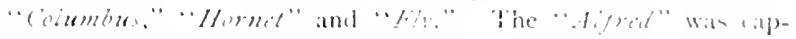

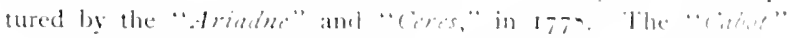

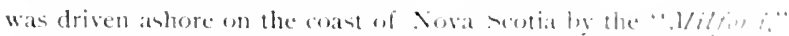
in 5777 and abandoned. She was afterward- hatuled ont and tahen

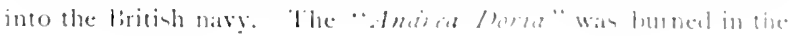




\section{CHAPTER VI}

THE CONSPIRACY AND DISMISSAL.

URING the time that the fleet was shut
up in Narragansett Bay, and while Hopkins was exerting himself to find men to man his ships, and struggling against all the opposition with which he had been constantly confronted, a scheme was set on foot to strike him a final blow and crush him completely. He was too active in some respects, if he was charged with inactivity by those who were far removed from the scenes of his labors. In the rearrangement of the nary list, in October, $17-6$, a law was passed regulating the rank of the officers of the navy and a lint of twenty-four captains approved. No special appointment or

I taware, in 1777 . to prevent her falling into the hands of the enemy. The "Protidanc" (sloop) was taken in the Penobscot. in 1779 . The "II"asp" is supposed to have been sunk in the I lelaware to prevent capture by the enemy. The "Prozidence" (ship) was captured at (harlenton in 1780 , and the " Warren" was burned in the l'enobscot in 1779 . (Naval IJistory of the (nited states, cooper, vol. 1, page 2+7.) 
confrumation of the former appointment was made respecting the commander-in-Chief. Hopkins beld this position by virtue of his first appointment, and although each of his old captains and some new ones received al special asignment of rank, his name and rank were omitted. Ife was not pepulat with Congress, and a way was left open. when the proper time should arrive, to dispose of him entirely, and at the sanse time provide against future treubles by makins no provision for such an officer. The time for such action soon came. It will be remembered that the committee of Khorle Island merchants and ship owners who had the charge of building the two vensels in that

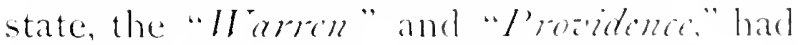
so far adranced in their work that in the carly spring of 17,6 thene verech were launched.

This committee, in addition to othere diuties and responsibilities, had the pewer to appoint offeces for the two ships. This was a duty mot easy to perform. There was mo lack of good men in the state for the sere vice, but government rerrice was not w their liking. it was less remuneratioe than that on private vesscls of war, and some of the 
very men on this committee were more interested in having their own privateers officered and manned than they were to serve their country's interests. This feature was one of the most troublesome with which Hopkins had to deal. The privateers took nearly all the available men, and the government ships were left with insufficient crews. It will also be remembered that he endeavored to secure from the legislature of the state an embargo until his vessels were manned but did not succeed in so doing. He did succeed, however, in arousing much opposition against him by the owners of these privateers, and they did not forget his interference. In order to secure officers for the ships, sub-committeen were appointed from the general committee, to go into the various towns in the adjoining states and pick up such men as they could find who would enter the service. These committees visited the towns of Boston, Dartmouth. Mendon, Bridgewater, Taunton, in Massachusetts, and other places, and secured men evidently competent to assume the cluties of the offices to which they were subsequently appointed. Among the men thus selected were John Grannis, Barnabas Lothrop, Samuel Shaw, James 


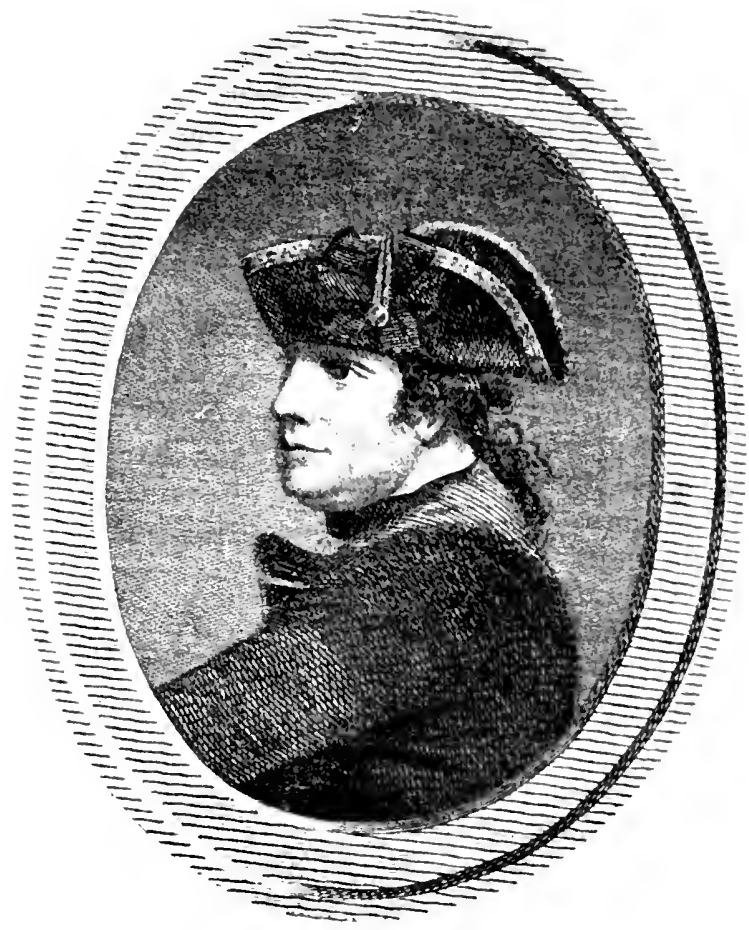

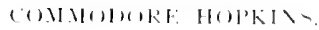

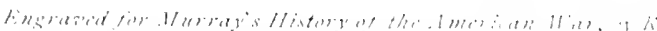

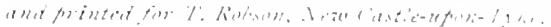

Fish an winal mrit:

Portrait Plate + . 

Sellers, Roger Iladdock, John Truman, James Brewer, John Reed and Ceorge stillman. There was yet another, Richard Marvin by name, who was a ship carpenter and had worked on the vesicelo now about to be put in commission. These men were all assigned to the "II amen," on which subsequently flew Hopkins' brod pennant. The most conspicuous of these men in the plet which afterwards developed were Marrin and Grannis. Little is known of John ciamnis. though be belonged in Falmouth, Masio, and was appointed captain of marines, June It. 1776 . It appears. howeres, that he was a willing tool of Marvin's, and from his rant lent some force and importance to the part which he was called upon to perform.

Marin, however, is better known, for in the latter years of his life he kept a private school in Providence, and had a large number of pupils, the author's grandfather being enrolled among them. Richard Marvin was bom in England, in 1 750 , and was, therefore, a young man when he entered the service of the colonies; he was by trade a ship carpentere he had received more than an ordinary education, was a fine penman, and there seems w be good reason for belief that he had served 
in the British nayy, or merchant service, in a subordinate capacity, where he had obtained some knowledge of seamanship and narigation. He received his appointment of third lieutenant on the " Marru," from the committee appointed to build the two ships, on April 30, r776. He was granted a pension on April 4, r $\$ 1 S$, "for eleven months actual service as a lieutenant in the U. S. nary" during the Revolutionary IVar. After the war Marvin took up his residence in Providence, where he lived until his death, June 17, i 826 . He was constantly employed in the ship yards, and on the public works of the town, until the early part of the present century, when he gave up his trade and opened a school for boys, on Pawtuxet street, now Broad street, opposite to Fenner street, which school was well attended. While he always signed his name "Richard" he was known far and wide then, and even to-day is referred to as "I)icky Marvin." He is described by one who remembered him well, as "a large, fat man, marked in his personal appearance as in his mental peculiarities;" another calls him a "peculiar character:" and another an "old time eccentric character," while one of his old pupils says, 
"Marrin was a very profane man, and a sperat reader of Thomas Paine." The comrensus of opinion of this old sailor man and perlatgog pictures him as an irancible, meeletlesome man. profane and vulgar in speech and habits. He was, howerer, a good sehoulmaster, and insisted on discipline, which he enforced with a birch switch: he was alore a most skillful penman and mate this study interesting for his pupils by writing degererel rhymes for them toropy. The author hold among his treasures an ancient copy book formerly belonging to his grandfather, uned while a pupil of Marvin's, which bears ample testimony to his qualifications as a penman. There is a deal of humor, as well as reason, in some of the rhymes which Marvin "set for copy." A boy who was not prompt in his appearance at the regular hour for (1) exning school, would find written in an elegant hand on his copy book:

"When you are sent to school sed out and run lont stop to play nor join in idle fum

but lay your course, port helm, and hrate away. And soon you'll land in Marvin's peaceful baty. "

All of Marvin's rhymes seem to have had a nautical flaror. Among his pupils wats James West, who was learning the trade of 
a caulker. He worked part of his time in the shipyard, and received instructions from Marvin during his spare moments. Mr. $\mathrm{IV}^{\top}$ est, in after years, well remembered this verse which his preceptor set for him to copy:

"Be wise and be industrious Jeams.

And drive the oakum smartly in the seams,

Bie faithful in your labors, for on you,

lepends the lives of seamen, the ship, and Cargo too."

Such was the man who became the ringleader in a miserable conspiracy to rob Hopkins of his good name, and to force his removal from the command of the American nary. How well this conspiracy succeeded, future events will disclose.

Long before this scheme was set on foot Hopkins had aroused the ill will, if not the enmity, of many of the influential merchants in Providence, by his efforts to stop the sailing of privateers. It will be remembered that he had gone before the legislature and endearored to have an "embargo laid upon Privateering in order that the Continental ships might be manned." His sensational charges against the foremost men of Proridence, who constituted the committee to build the two war ressels, had produced 
much feeling against him, and the disomelee with which this committee had terminated its career shows plainly enough that the members were angered and embittered by his interference.

There was a spirit of tomeret, tow, amomes the offecers and men in the shipe at this time, and the opportunity of using this comdition to the detriment of llopkins wan taken advantage of by some of the men whom he had antagonized. It was, evidently, determined that certain charges should be mate against him by such officers in the fleet an were unfriendly to their commander. IIho these men were cannot now be definitely stated. Hopkins refers to them in a letter to William Ellery as "some of the Gentlemen of this Town. (Providence) I suppose the owners of the Privateres, who 1 am sorry to say are greatly prejudiced against me."

With this substantial backing of men of such influence and wealth it was an ca-y matter to enlist the sympathies of these iclle and restless men in the fleet in an! properition to attack the commander.

This attack came from the ship) "I/ (trom." on which Hopkins had hoisted his bmad 
penmant. and came in the form of a petition to the Narine Committee.

Early in February, 1777 , this petition was drawn up and quietly circulated among the officers on the "Itarren," and it was subscribed to by Roger Haddock, John Truman, James brewer, John Grannis, John Reed, James Sellers, Richard Marrin, Ceorge Stillman, Barnabas Lothrop, and Samuel Shaw. Some of the officers to whom it was presented, however, refured to attach their names to it.' All these men, with the exception of Marvin and Haddock, were residents of Massachusetts, Marvin being the only Rhode lsland man among them, and he a resident of Providence. Haddock belonged in New York, and was master of the " $/ \mathrm{F}$ " ren;" Truman was a gunner, and Brewer a carpenter, both of Boston; Grannis was captain of marines, and belonged in Falmouth; Reed was the chaplain, and belonged in Middleborough; Sellers was second lieutenant of marines, and came from I artmouth; Stillman was first lieutenant of marines, and came from Barnstable, as did Lothrop, who was a second lieutenant of marines; 
Shaw was a midshipman, and belonger in Bridgewater. 'This petition, to which thene men subscribed their names, was as follow-:

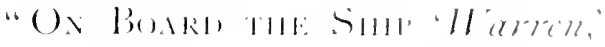

$$
\text { (i) (a) } 10.17 \%
$$

Much Kespicted (ientlemen:

11 e who present this petition. emgaged on

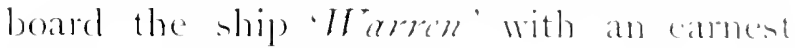
desire and fixed expectation of doims our country some service. Me are still anxious for the IVeal of Incrica \& wish mothing more earnestly than to see her in peace $\mathbb{d}$ prosperity, IVe are ready to hazard every thing that is dear \& if necensary, sacrifice our lives for the welfare of our country, we are desirous of being active in the defence of our constitutional libertice and privilenes against the unjunt crucl claims of tyrams. \& oppression: but as things ate now circumstanced on board this frigate, there seems to be no prospect of our being serviceable in our present station. Me hase been in this situation for a considerable space of time. Ne are persomally well acquainted with the real charater $\&$ combluet of our commander, commorlore llopkins, \& we take this method not having a mome 
convenient opportunity of sincerely \& humbly petitioning, the honorable Marine Committee that they would inquire into his character \& conduct, for we suppose that his character is such \& that he has been guilty of such crimes as render him quite unfit for the public department he now occupies. which crimes, we the subscribers can sufficiently attest.

P. S. Capt Granis the bearer of this will be able to give all the information desired.

Roger Haddock
John Truman
James Brewer
John Granis
John Reed
James Sellers
Richard Marvin
George Stillnan
Barnabas Lothrop
Samuel Shaw'

To the honorable Narine Committee"

Besides this general petition all of its signers subscribed to separate papers in

From a copy of the original laid before Congress. Tee also Hopkins l'apers, vol. 3, page 10. 
which each made specific chargen againet the commander.

By these Hopkins was charged with profanc swearing in common conversation, cursing the Marine Committee and calling its members as well as Congress itself "ignorant fellows-lawyers clerks-persons who dont know how to govern men; " his conduct in the management of the fleet was also comsplained of. The most temperate of all there individual charges was that of John Reerl, the chaplain, and on account of some of its statements is important in arriving at a just conclusion as to what there was in the minerable scheme.

Reed's testimony against his commander was as follows:

$$
\text { "ON BOARH, THI: "Il'arru, }
$$

$$
\text { Feb. 24.175\% }
$$

I the subscriber do know that our commander, commodore Hopkins, allows himself to speak in the most disrespectful manner concerning the honorable Continental Congress, although I have lived in the cabin with him, I do not remember that he har ever once spoken well of those guardians of America, but seems to embrace erery oppertunity in order to disparage $\mathbb{E}$ slander them. 
He does not hesitate to call them a pack of ignorant fellows - lawyers clerks - persons that don't know how to govern-men who are unacquainted with their business-who are unacquainted with the nature of mankind-that if their precepts $\&$ measures are complied with the country will be ruined. I have also heard him say that he would not obey the Congress. He not only talks about them most disrespectfully among our own folks but I have heard him exert himself earnestly in order to disparage them before strangers, before two prisoners who were masters of ressels on their passage to Newport in order to be exchanged. He also positively asserts that all mankind are exactly alike-that no man ever yet existed who could not be bought-That any person living could be hired with money to do any action whatsoever. This he also asserted in the hearing of the before mentioned prisoners, for what reason I can't determine unless he was desirous of making a bargain with Sir Peter Parker.

He allows himself in anger $\&$ in common conversation to take the name of Cod in vain; he is remarkably addicted to profane swearing. In this respect as well as in many 
other respects he sets his officers $\&$ men il most irreligious \& impioun example. I le. has treated prisoners in the mont inhumbun and barbarous manner-l rery well know ly hearsay, how he has conducted in regard to his men's being paid off \& being dincharged when the term of time for which therengaged was expired. In this part of America pere ple are afraid of him. They are jealuse of him $\&$ he is an effectual obstacle to the fleet being properly manned. He is rere much blamed by people here for not dentroging a British frigate when aground a few day a age in this river. I am not prejudiced against the man. My own conseience, the regard I have for my country and the arlvice \& carnest desire of many reppectable sentlemen? have induced me to write what I have written.

$$
\text { J1H: RH:." }
$$

As soem as the signatures had been wbtained these documents were intrunted to (aptain John (irannis, who, without so much as asking leave of absence, quictly denerted the ship and set out for Philadelphia to

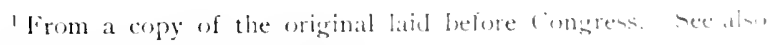
Ilopkins lapers, vol. 3. page 14. 
present the petition to the Marine Committee. Hardly had Grannis left the "Warm," when Shaw, Reed and Haddock, who had signed the petition, appeared voluntarily before Hopkins and frankly admitted they had signed a petition to the committee derogative to him, and confessed that they had been induced to do so "by some Gentlemen of the town." Further inquiry brought Hopkins the information that Grannis was missing from the ship without leave and the names of some of the signers. With this information be at once addressed a letter to William Ellery, a delegate in Congress from Rhode Island, in which he says:

"I have lately understood by two or three officers of the ship "IVarm," who came voluntarily to me; that they had been Induced to sign some paper or Petition greatly to my disadvantage: which they were perswaded to by some of the Gent- ${ }^{n}$ of this Town, I suppose the Orners of the Privateers, who I am sorry to say are greatly prejudiced against me, since I endeavoured to get an Limbargo laid upon Privateering in order that the Continental ships might be mann'd-And as for Captn. Grannis who I understand is gone to you with it, I am 


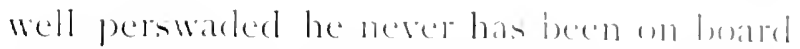
the ship three nights together, mor I betiene ten days this fire momthe past-and all that he can have agains me a we alle entime strangers, is that after sereat times deniring him to go om board and do his duty, at the ship was liable to be attack'd at any time: I at last threatend to break him and sot another man in his Room if he did motupon which he went on board but staid only two nights-and this single thing must Convince every Impartial Person, that for an officer of a Ship to kave her without the knowledge of the Captain or Licutenant. when she was in danger of being attack'd every day being within ten miles of somes, $\mathbb{S}$ twenty of ten or twelve Men of 11 ar, some of them stronger than her, two homr fair Wind would have brought them along side; and to go such a Journey without first endearouring to Remedy the Evil if there war any, cannot be a Fricud to his Commtiy, but must act upon some private Viem, which I make no doubt he did to serve some of the men perhaps that made him, much in the same manner as they finished the shipe. who have cost your. Igent near if not quite ff fooo-which was absolutely necenaly for 
them before they could be ready for the Sea-and that you will soon be convinc'd off by his accounts, which he says you will have soon and they are near if not double the Prices first Contracted for, owing to some of the very Committee that built the Ships, taking the Workmen and the Stock agreed for, off to work and fitt their Privateers; and even threatning the Workmen if they did not work for them-I am very willing to come to you to answer for my Conduct with such of the Committee who built the Ships as I could name-but not with the poor men who only acted as Machines to a Sett of Men who I wish I could say I thought had any other principle but avarice-and it would have been full as well if some of the Officers had brought in such accounts for Enlisting men, that they might have been Settled with on any other Terms, but signing that Paper against me. And it will be well if you don't find them Extravasant, as the Committee did not chuse to pay them, but gave em Orders on the Agent for the Money-

Inclosed you have a Copy of one of the Officers accounts-and I believe you will find in the Committees account whenever it 
comes to hand, another larese sum and all for Enlinting men; but few of whom exer came. on board the ships. though I cant say they did not go on board the Privateers- 11 henever I am calld for I think I can Speati the Truth, and not Stab a man in the dark-

What the purpert of the Complaint which Capt Grannis may have brought is, I de not know, but as the Men that signel it know but little, and are worth le-s as Saikme, all I shall say more is to Inclose a Copy of what three of them Volmntarily Signd being Comscious they had done wrong-

This one thing I can Say, and with Truth, that I engag'd in this dispute on no wther design than to serve my Country-and I still am determined not to desert the Canse -but whenever you or the Congrem think you can get a man in my room that will be of more service to the Cause than I cam, nou have my leave, and in Justice to the Commery I think you ought to do it-and I shall still Continue to do what good I can, in a lens Enyy'd and lesis troublesome way

Giannis proceeded to Philadelphia and upon his arrival promptiy appeared befure the Narine Committee with the scurritous 
documents which had been entrusted to him. Eren with the prejudice which the members of the committee had against Hopkins the allegations contained in the papers presented were too serious to be at first believed. After deliberating over the whole matter for some days it was resolved to summon Grannis before the committee and examine him personally as to the charges that he and his fellow officers had made A subcommittee was appointed to "examine John Grannis on the subject matter of the petition." The testimony before this committee was not under oath, Grannis merely answering the questions put to him by the committee.

After the usual questions as to his name, residence and occupation, the examination proceeded as follows:

"Q. Are you the man who signed the petition against Esek Hopkins, Esq by the name of John Granis.

A. Yes.

Q. Do you know the other subscribers to said petition

A. Yes

Q. Are any of them officers of the "Iarru, \& if officers what office do they sustain 
1. John Reed is chaplain \& belonge to Middleberough \& fames Seller is Second lieutenant of the 'Theren' \& of l)artmonth. both of Mansachusetts liay Richarel Marvin is third Lieutenant \& of Providenee (ientege stillman first L, ieutemant of Marines, Barnabas Lethrop Second Lieutenant of Marines both of Barnstable, Samucl Shaw is a Miclshipman of Bridgwater Roger Haddeck is master of the frigate \& formerly wan of Nell York, \& John Truman is gunner, \& Jamen Brewer Carpenter \& both of boston in the State aforesaid.

Q. Have you a personal acquaintance with Esek Hopkins lisc

A. Yes. I have had a persomal acquaintance with him since I came on this ship

Q. Did you ever hear him say anything disrespectful of the Congress of the L nited States \& what \& when.

A. I have heard him at different times since I belonged to the frigate speak distespectfully of the Congress have heard him say, that they were a set or parcel of men, who did'nt understand their business, that they were no way calculated to do business, that they were a parcell of lawyers clerks, that if their measures were followed the comntry 
would be ruined $\&$ that he would not follow their measures. I have heard him say the abore in company on ship board \& words to the same effect on shore. Sometimes the above was spoken of Congress in general but more frequently of the Marine Committee.

Q. Did you ever hear him speak disrespectfully of Congress or the Marine Committee before prisoners.

A. No I never was in his company when prisoners were present.

Q. Do you know anything about his treatment of prisoners

A. I was on board the frigate 'Proz'i dence, when there were about 20 prisoners on board. They were called into the cabin where I was \& were asked by Capt. Whipple, whether they would do ship's duty. They answered No. Capt. Whipple said it was his orders from the Commodore to put them in irons, to keep them on two thirds allowance \& by God, he would obey the commodore's orders. They were sent out of the cabin with an officer who returned $\&$ said he had put them in irons. There were also some prisoners sent on board the frigate 'IVarrn, who were forced to do. 
ship's duty by commodore Hopkins orters S he refused to exchange them when a cartel was settled \& other prisoners were exchanged, but don't know that it was their turn. The reason be assigned for not exchanging them was that he wanted to have them enlist on board the frigate

Q. Do you know anything about a British frigate, being aground last winter in the river or bay leading up to Providence in the State of Rhode lsland \&c, and what.

A. I did not see the "Diumond" frigate while she was on shore in Jan last I was then ois board the "I 'arren', which with the Continental fleet lay just above a place called Field's Point Commodore Ilopkins went down the river in the stoop "Prosidence's sometime after he returned, I heard him saly that the people in Providence blamed him for not taking the 'Piamond,' but that the men were not to blame, for they went as far as he ordered them \& would have gone further if he would have permitted them, but that he did not think it safe to go with the sloop, for that the "I Diamond' fired orer her I heard a number of people who said they were at Warwick neck, when the "Dimmond" was aground there, say, that commodore 
Hopkins was so far off the ship, that his shot did not reach her, that the ship lay so much on a careen, that she could not bring any of her guns to bear upon the sloop; and further I heard some American seamen who were prisoners when the 'Diamond' was aground say, after they were exchanged, that the ship lay so much on a careen, that they could not have hurt the Sloop's people so long as they kept out of the reach of her small arms. They also said, that it was the intention of the enemy to have fired the ship $\&$ left her if the sloop had come near enough to have played upon her. One of the seamen who told me the above was - - Weeks, $\&$ another of them was named Robinson Jones both of Falmouth aforesaid \& young men of good general reputation

Q. Were the frigates manned when you came from Providence.

A. No. There was then about roo men on board the 'Harren', \& I heard some of the officers of the frigate 'Proaidenc' say, that in last December they had on board about r 70 men \& the last of February I heard them say, that so many of their men were dead \& ran away, that they were then not better off for men than the "Tarren.' 
Q. Commodore Hopkins is charged wih being a hindrance to the proper manning of the fleet, what circumstances do you know relative to this charese

A. For my part his conduct and compersation are such that 1 am not willing to be under his command. I think him unfit to command \& from what I have heard officers \& seamen say, I believe that it is the general sentiment of the fleet $\&$ his conversation is at times so wilel \& orders so unsteady that I have sometimes thought he was not in his senses \& I have heard some others say the same. And to bis conduct \& conversation it is attributed both by people on board the fleet as well as by the inhabitant of the State that the fleet is not manned. It is generally feared by the people both on boarl the fleet as well as ashore, that his commands would be so imprudent that the ships would be foolishly lont, or that he would foresen opportunities of getting to sea or attempt it. when impracticable. The seamen betonging to the 'Columbus' left her when their time' of service expired \& went inte the army \& 1 heard some of them say that they would not enlist again into the Continental fleet solums as Commodore lopplins had the command 
of it. The character that Commodore Hopkins bore was a great hindrance to me in getting recruits.

Q. Had you liberty from Commodore Hopkins or Capt Hoplins to leave the frigate you belong to.

A. No I came to Philadelphia at the request of the officers who signed the petition against Commodore Hopkins \& from a Zeal for the American cause.

Q. Have you, or to your knowledge either of the signers aforesaid any difference or dispute with Commodore Hopkins since you or their entering into the service.

A. I never had, nor do I believe that either of them ever had. I have been moved to do \& say what I have done $\mathbb{E}$ said from love to my country \& I very believe that the other signers of the petition were actuated by the same motives."

This testimony being committed to writing was signed by Grannis. It was not until March twenty-fifth that the committee was prepared to lay the matter before Congress, but on that day the Marine Committee "laid before Congress a paper signed by sundry

${ }^{1}$ From a copy of the original laid before (ongress. See atsi) llopkins l'apers, rol 3. parge 15. 
officers in the fleet containing chargen and complaints against Commolore beck I Iopkins."

These papers were read and the whole matter haid upon the table. The next day (March twenty-sixth) the matter was taking up, and without any discussion it wan "Resolved, That Esek llopkins, be immediately and he is hereby, suspended from his command in the Imerican Nayg."

About this time, while I lopkins was harrassed by the contentious spirits around him, he learned that his son Esek, a yoting man nineteen years of age, was a prisoner of war at Ialifax. Young Esck I Iopkins had gratwated from Rhode Island College in the clans of 1755 and almost immediately entered the navy as a midshipman, and was assigned to the "Alfred," the flag-hip. He rapidly rose to the position of licutenant, and while acting in this position on the "/ residenes" (sloop) he was captured by the British and taken to Halifax. Through the influenee of his father the (ienceral Assembly passed an act requesting Major (ieneral spencer, then in conmand of the Continental forces in Rhode lsland, to exchange l, ieutenant () way. of the British frigate "Lark," who had been 
captured by the state troops, for the son. No such exchange, however, took place, for young Hopkins sickened and died while a prisoner in the hands of the enemy. He was a young man of much promise, and his father, no doubt, felt his loss keenly.

Meanwhile extraordinary proceedings were taking place in the fleet. Hopkins was incensed at the underhanded and improper manner in which the complaint of his subordinates had been brought to the attention of Congress. As the head of the navy he had been ignored and insulted, and he resented it squarely.

before Grannis had reached Philadelphia the whole plot to deprive Hopkins of his command and put a blot on his reputation had been exposed. The master of the "Harrn," Roger Haddock, chaplain Reed, and midshipman Shaw, who had come to realize the enormity of their acts, presented themselves before their commander and acknowledged their offence; at the same time each subscribed to a document very different in tone to that which had been entrusted to Grannis for the perusal of the Marine Committee.

Hopkins closely questioned the three men 
and ascertained the true state of the whole business. He learned that the plot had ori. ginated outside of the fleet, and that the men on board the "llarre" had been easily" drawn into the scheme through the influence of the erudite Marvin. It is interesting to observe the difference in the declarations made by Haddock, Reed, and Shaw, after they had confeseed their part in the plot, from those to which they had previously subscribed their names. Haddeck: was in the following words:

$$
\text { "Sinp 'Warren' March ye so } 1777
$$

I the subscriber do hereby say that I know nothing either of the public or private character of Commodore llopkins an being a stranger, nor know not that he has dome anything detrimental to the cause he in now engaged in at Present

Rogis Handerk.

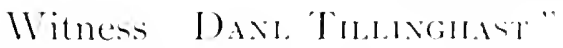

Reed subacribed to the following:

" 'This may certify"

That I the subscriber in my own person have been treated complacently by commodore Hopkins \& dont know that he has 
designedy acted in any one instance inimically to his country but that according to the best of his abilities, suppose that he has acted consistently therewith

Providexce $1+$ March 1777 Johx ReED

Witness at Signing SAM Lyon."

While Shaw put his name to the following statement:

"These may certify

That I, the subscriber have been treated by Commodore Hopkins since 1 have been in the nay with the greatest politeness and decency and never have thought that he has been inimical to his country designedly, but has according to the best of his abilities acted consistent therewith

SAMLEL SHAW

Provinexce March i 1777

Witness at Signing S.lu Lrox."

For some days after Hopkins had obtained the information of this attack upon him he deroted himself to quictly investigating the matter. I buring this time he ascertained that Lieutenant Richard Marrin, of the " I/ arren," had been the prime mover in circulating 
the scurrilous documents abent the ship. and that his relations with ecrtain men in the town gave color to the suspicion that he was the ringleader in the plot. Itopkins therefore placed him moler arrest, and on the third day of Ipril, 1777, he wat tried by court martial held on board the "I"reridence," then lying near Fields Point, in Providence River, for circulating a "scurrilous paper or papers signed by him and sent away in a private manner against the commander in Chief."

This Court comsisted of Captains Mbraham Whipple, John B. Hopkins, Hoysteat Hacker. Jonathan P'itcher, Silas I evoll and Joseph Hardy, and lieutenants Milliam Grinnell, Robert Aclameon, Milliam Barron, Philip Brown, Adam II. Thaster, Seth Chapin and Edward linke. The comt organized with Abraham IVhipple president, and Marvin was presented and anked if he

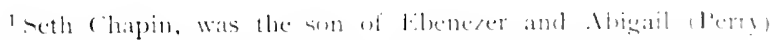

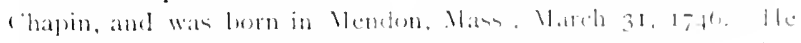

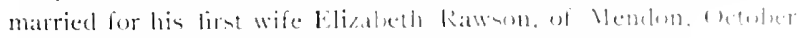

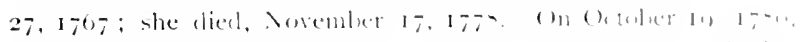

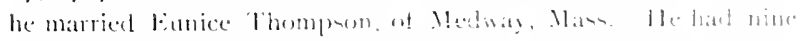

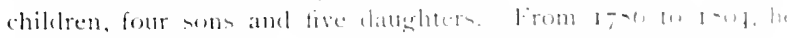

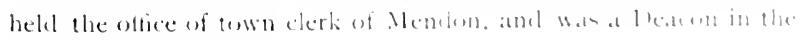
forgregational churrh. 
was ready for trial. L jon answering "Yes, - I am ready" he was then sworn and examined as follows:

Capt IIhipple Q. "I)id you ever Sign any paper or Petition against the Commander-in-Chief or against any officer in the Fleet to ba sent to Congress

1. Yes-

During the war of the kevolution, Seth chapin served with distinction. Ile was corporal in Captain Iohn Albees' company, which marched on the lexington alarm April I9, I775, from Bendon to Roxbury, and served nine days.

lecember 10. 1775 , he was a corporal in Captain Iob Taylor's company of Colonel Ioseph liead's regiment.

July $9,17-6$, he was second lieutenant in captain camuel Crayin's First Company of the Thirel IVorcester County regiment. l'revious to this, on June 24,1776 , he was appointed second lieutenant of Marines on board the ship "Presidince," and on ceptember $1+17,0$, he was ordered to J'ymouth, Mass., to enlist men for the nary.

lle did not serve long in the narine corps, for in the same year. he seried as First Lieutenant of Mool's Regiment of the Massachu-

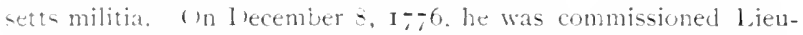
tenant in (aptain Samuel (ragin's Company, l jeutenant Colonel Nathan lyler's regiment; he was discharged, January 21, 17.7.

Iuly 10, 1777 he was l“irst l,ieutenant in Colonel sherburn's additional continental regriment which commission he resigned Ipril 10. 17:0.

1 is most daring exploit was on the night of l lecember $17,17 \%$. when, in a mall boat with six men lue captured a liritish brig in the feaconnet river. He also carried on secret communication with lsatc barker, a farmer in Ylddletrwn. K. 1., while the liritioh held possession of Newport and the island of Rhode lsland. Warker. Who was a staunch patriot, lived at his home in Middletown. and was in the midnt of the british forces, indeed lititin officers 


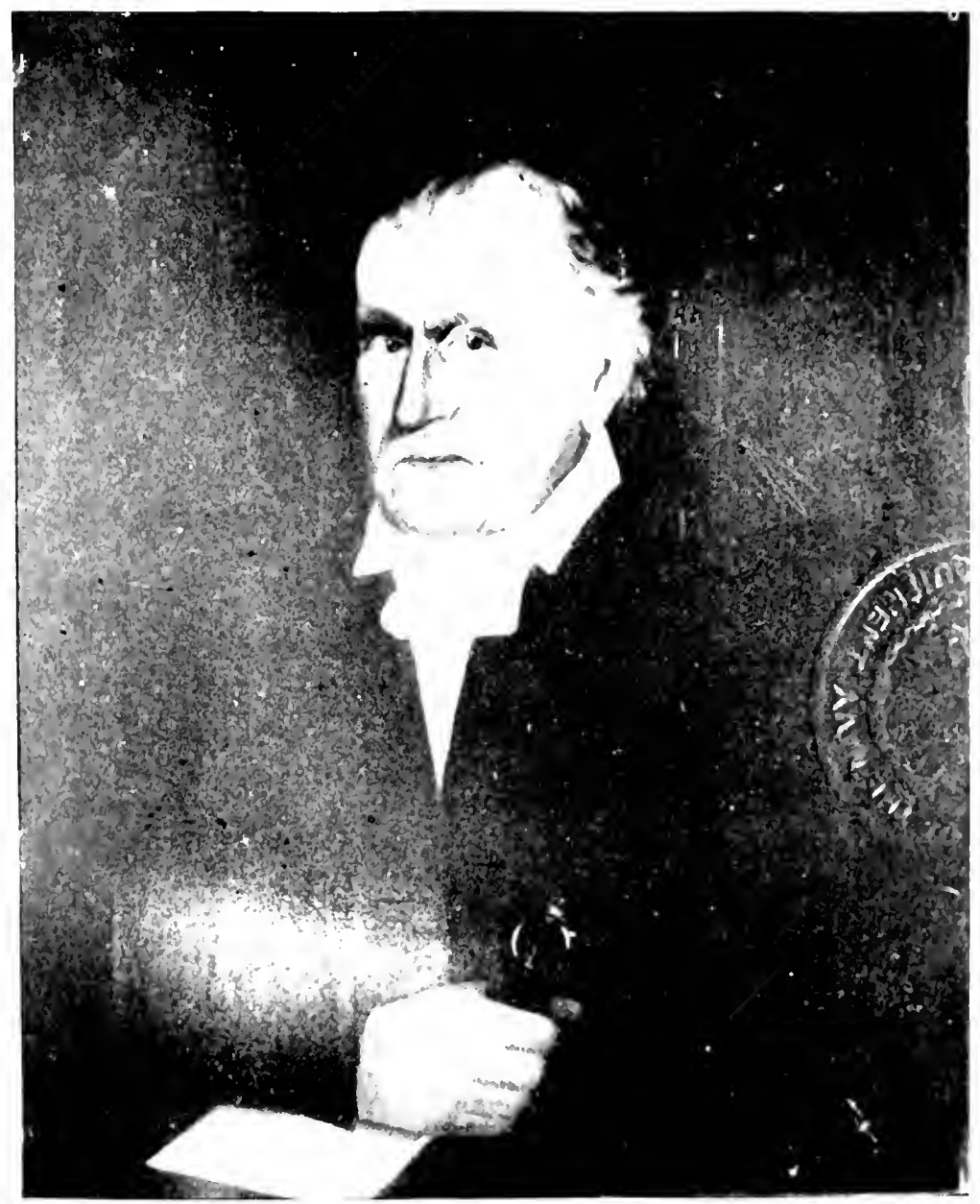



C. Irill you produce the Copien of sueh Papers as you have Signed and Sent to this Court

4. They are not in my possession and if they were i would not

Capt Whipple O. Mhy did you not at the time you sent those papers inform the Commander in Chief or Captain I Iopkins" of it

were efuartered at his hense, but by eignals which he mate lo artanging his bate at a gateway, he was enabled to convey informat

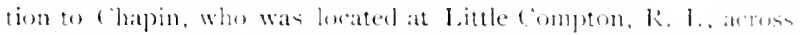
the seaconnet river. Which was of the areates importance to the Intericans. This was arricel on sucessully for nearly fourteen months, of until the liritish eracuated Vewport.

firom official muster rolle it appears that he was comminsioned

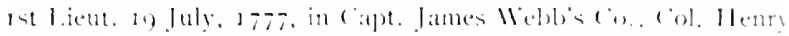

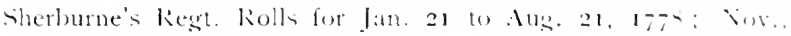

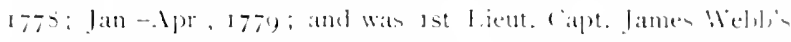

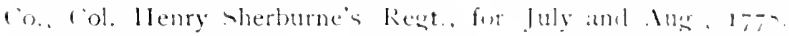
Rell dated at camp at R. 1, 21 Aug., I775, reported an suard.

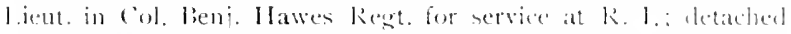

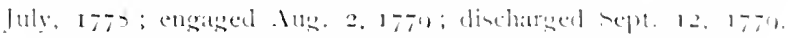

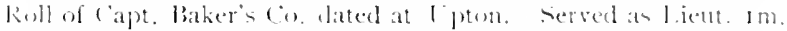
151). in Capt. ('ragin's co., (i)l. Mawe's kegt. at the time the

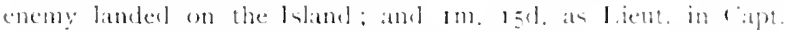
I. Y. baker's 1 o. during sullivan's expedition, in 1 ;

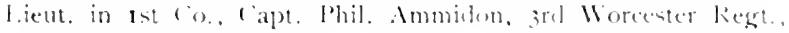

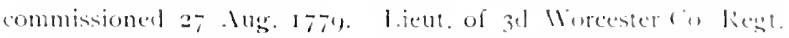

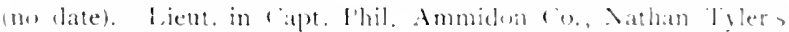

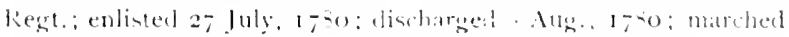

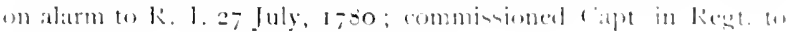

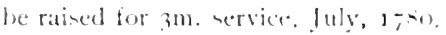

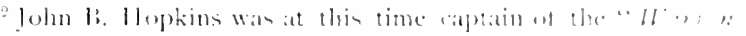


A. Because the act of Congress Says we shall quietly and decently make the same be known to our Superior Officer

Q. I)id you Sign any Paper against any other Officer but the Commander in Chief-

A. I have no answer to make to that

Q. How many was there that signed those papers with you against the Commander in Chief

A. The Congress can make that known

Q. What was the reason you did not acquaint the other officers in the Fleet of it as they might have signed the Petition or other papers which you have Sent to Congress

A. Because we thought they were not so thoroughly acquainted with the Facts, that we Sent to Congress as we were

Q. Nlas any person in Providence or within this State directly or Indirectly at that time knowing of any such Petition being Sent to Congress

A. I believe there was

Q. What is their names-

A. Their names will appear to a greater Advantage hereafter

Q. Who was the first promoter of drawing \& sending this Petition

A. I cannot tell distinctly 
Q. Nas Henry Marchant Eeqr' comsulted in drawing this Petition

A. I am not certain-

Capt Kopkins Q. What was the Contents of the Petition sent to Congress against the Commander in Chief

A. The facts were of such a nature that we thought it was our duty to our Country to lay them before the Congress

Commodore Kopkins (2. What Country was you born in

A. I was born in England, but america is grown dear to me

(2. Was there any more signed the paper or Petition besides Yourself

A. Yesthere was-

Q. How many do you think there was

1. I camnot give you a direct answer

Capt Mhippli Q. Would you tell hum many signed it if you did know

. I. If I knew exactly I would

(). Will you tell the number that you know Signed it -

1. Have I not answerect a similar Dutestion put to that already

cipt lloptins Q. What did you civer

'Henry Marchant was a delegate to the dimbinental dingren

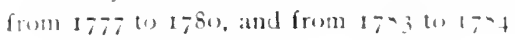


See in the Commander in Chiefs Conduct that gave you any cause to Sign and Send any paper to Congress against him or did he ever treat you or any Officer on board with any disrespect to your knowledge-

A. Some thing that I thought was in. jurious to the publick IVellfare-

Commodore Hopkins Q. What was it that ever I did that was Injurious to the public Wellfare-

A. A number of Fact coming to our knowledge which we thought was our duty to Submit to Congress

Q. I 0 you remember what the facts were

A. I do remember

Capt Whipple Q. If you remember will you tell what they were

A. Whenever Congress or any body authorized by them, calls upon me I am ready to relate the Facts

Q. I) you think you was acting in the character of an officer when you made $\mathbb{E}$ Signed a Complaint and sent it away privately against your Superior ()fficers-

1. I think I was-

Capt Hopkins Q. do you (personally) know of any fact you ever Saw that the 
Commander in Chief eommitted which you have signed and sent to Comgrens

A. I refuse answering to that until such time as I appear before Congreso or a committee authorized by them to incpuire into the affair

Mr Adamanen lde of the Iferren was asted the following Ouestions:

commedore /toptins O. Wan you non asked to Sign that paper that Capt Ciramis carried to Congress

A. Yes

Q. W'hat was the reason you did not

1. My reason was that the Facts mentioned against the Commander I did not know to be true.

Commodore Hopkins (). 1) you know any of the facts charged against me

A. You was charged with saying that there was no man but what could be bought and that the Congress was made up of Merchants, Clerks, lawyers, and boys

() How many do gou l'nderstand signd the Petition

A. Eight

Mr Tharter to Mi Marvin

C. Nas the Chief mate of the $/ 1$ are ren asked to sign the lectition against 
Commander Hopkins that was sent to Congress

A. I don't know that he was

Capt Whipple Q. Was there any Complaint Sent away with the Petition against any other Officer or by those belonging to the 'Warre'l '

A. None that I know off-

Capt Ithipple Q. Have you anything to say to the Court in your own defense

A. I have nothing very material" "

Upon the conclusion of this trial the Court recorded the opinion that Marvin had "treated the Commander-in-Chief of the American Navy with the greatest indignity, and defamed his character in the highest manner by signing and sending to the Honorable Continental Congress several unjust and false complaints against the Commander-in-Chief in a private and secret manner, and also violating the 28 th 29 th and 3 ist Articles for the Regulation of the American Navy, which they think is acting beneath an officer of his station."

The Court also rebuked him for the

From the original record of the court martial in llophins l'apers, vol. 3. page 2. 
insulting manner in which he had condheted himself before it, and for this considered him "unworthy of holding a commission in the American Navy." The order of the conte was, "that lieutenant Richard Marvin forthwith deliver up his commission to the Commander in Chief-and in cane he should refuse to do it that he be put under immediate Confinement until he comply with the Resolve of this Court."

()n the same day the findings of the Court were confirmed by the Commander-in-Chief.

Marvin's career in the American Navy terminated with this act. Ile had received his appointment as Lieutenant on April 30 . 1776 , and on April 3, r777, he was dishonorably discharged. For these eleven months" service, much of which time he had devoted to breeding discontent among his asonciates and indulging in underhand methods again-t the Commander of the Nary, he afterwards received a pension from the United States.

News and the post travelled stowly in those days. Nore than a week before this court martial had convened Congreso had suspended IIopkins from hos command in the Nayy, yet he was as ignorant of it as though such an order had never been paseed. 
It was not until the fifteenth day of April that he was notified of the action of Concress, but on that day Daniel Tillinghast, Continental Agent for Rhode Island, at half past two o'clock in the afternoon, placed in the hands of Esek Hopkins a copy of the order suspending him from his command, certified and attested by John Hancock, president. Without a hearing. without the privilege of saying one word in his own defence, and without so much as the formality of a trial, the Commander-inChief of the Nary had been summarily suspended from his command and his good name had been assailed. Such proceedings. however, had not been without precedent. Others high in official position had been thus served, and others were destined to feel the keen darts of insult. To a man of Hopkins' temperament, who had for years been accustomed to rule, who was working earnestly and feartessly in a cause in which he had enlisted heart and soul, the action of Congress came with crushing force: a weaker character would have succumbed with the shock. Hopkins, however, was made of sterner stuff.

About the time that Hopkins received the 
formal order of his suspension he alore res ceived a letter from his friend William Ellery, then representing Rhode L land in the Continental Congress. in which he expressed his regret at the action of that boely: To this letter llopkins responded on the zoth of April. Notwithstanding the sreat injury that had been done him and the humiliation which his suspension had brought, this letter shows the manly spirit with which he received this verdict and his undiminished patriotism. Thus he writes:

$$
\text { "Providence, April 2oth 1777- }
$$

To the Hon Whan Ellekl Eos.

$$
\begin{aligned}
& \text { Member of the Contl Consuriss at } \\
& \text { Philada. }
\end{aligned}
$$

Sik I receiv'd your esteemel Farour of Town meeting day junt time enomgh to gee chose a deputy for this Town,-had I receiv'd it a Week soomer perhaps I might have been at the head of the P'rox-

Altho' I have lost the Interest of a pareel of mercenary merchants ()wores of Privateers, I do not think I have lost it in the Major part of this State-l heartily wish the Fleet may do well in the way you have directed it-I am obliged to you for your 
advice to continue a Friend to my Country, and you may depend I shall, should I have a few Friends in it-neither do I expect to remain Inactive-

I can assure you it gives me great Satisfaction that in my own judgment I have done everything in my power (or would have been in any other mans power in my place) for the Service of my Country-One thing I must ask, and shall think I am not well us'd if it is not granted- That is an attested Copy of a paper or petition Sign'd by some of the Ship 'Thmen' Officers. and perhaps some other men to the hon. Marine Board, or to Congrens-Should it be in your power to obtain it please to send it soon-if not, please to let me know the reason why I am not to be allow'd it-and you will much oblige

\section{Sir \\ Your real Friend \\ Esek Hopkins."}

In compliance with this request for a copy of the petition which had been sent to Congress, a resolution was passed, on May I 4 . directing that a copy of the complaint made 
by the men on the "Ifaren" be delivered to Mr. Ellery for the use of Itopkins. Ile repeatedly requested that this order of cingress might be complied with, and it was not until several months afterwards that he received these copies and learned exactly the charges that caused his suspension.? IIopkins remained under suspension until Jinuary 2, r77s, when he was summarily dismissed from the service of the United States. It is sometimes stated that he refused to appear before Congress after he had been suspended and answer the charges made against him, and for this neglect Congress rebuked him; there does not appear. however, any evidence to substantiate this statement. The scheme of his enemien had succeeded, he was no longer in the way, the nefarious plot of a few skillful men had prevailed. Smarting uncler the sting, and knowing that he would receive no comsideration from Congress, be determined to bave justice done him in a court of law. He therefore consulted with Rouse J. Helme, a leading attorney of the state, a man of sreat

1 The last otheial letter recorded in the orelers and letters if the Commander-in-Chief of the Xary is dated July 4,1777 , a d is a request to William Ellery for a copy of these charges. 
influence and activity in its affairs, and it was decided to bring a suit for criminal libel against the officers who were concerned in the conspiracy, with damages laid at $f$, I o,ooo.

This suit was begun by a warrant issuing out of the Inferior Court of Common Pleas, of Rhode Island. on January 1 3, 1778, directing the sheriff of the county of Providence to arrest the bodies of Roger Haddock, John 'Truman, James Brewer, John Granis, James Sellers, Richard Narrin, George Stillman, Barnabas Lothrop, Samuel Shaw and John Reed, and have them before said court on "the third monday in June" following.

This warrant was placed in the hands of Martin Seamans, sheriff, who subsequently made return of service on Samuel Shaw and Richard Marvin, the other parties, defendants, doubtless being without the jurisdiction of the court. Both these men gave bail, the former presenting Ebenezer Sprout, of Middleborough, Mass, the latter furnished John Brown, of Providence. It is significant that the leader in the conspiracy, who had been dishonorably discharged from the Navy for his participation in the scheme, found a sponsor in the person of one of the members of the very committee that Hopkins had 
charged with matfeasance in office, and which committee it was alleged had instigated the. charges to deprive him of his command. This case was heard at the June term of the. Inferior Court of Common l'leas, to which the writ had been returnable. Soon after being arrested on the libel suit, Marvin and shaw presented a petition to Compresis, repreacenting that they had been made defendants in a suit-that they were without the means w defend themselves and were put to much trouble and charge, and asked Comgres. to defray the expense of their defenee. This petition was considered by congres. and on the thirtieth of July an act was passed giving them the relief prayed for and on the nest day the following letter from Henry Laurens, president of Congrens, wan sent to the petitioners transmitting a copy of the act of Congress:

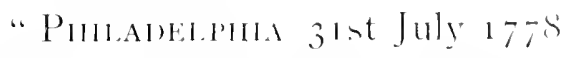

Gentennex Inelosed with this you will receive an Act of Congress' of the joth inst

$$
\text { "IIN CONGRESS IIII 30 1775. }
$$

The committee to whom was referred the petition of kichart Marvin and samuel shaw brought in a report which was taken into consideration whereupon

Resolved, that it is the duty of alt peroms in the servine uf the 
for defraying the reasonable expenses of defending the suit against you by Capt Esek Hopkins, together with attested copies of the records of Congress respecting his appointment $\&$ dismission to $\&$ from a command in the Continental navy

\section{l an Gientlemen}

\section{Your most obcelient servant}

\section{I lexkP I.ALRExs Presd of Congress}

P. S. inclosed is a duplicate of the Act of Congress of the $30 t h$, which if necessary you will deliver to the Inferior Court

Mesers Richard Marrin \& Samuel Shaw Providence"

I'nited states as well as all others the inhabitants thereof, to give the earliest information to congress or other proper authority of any misconduct, frauds or misdemeanors committed l)y any officers or persons in the Service of these states. which may come to their knowletget

Whereas at suit has been commenced by Esek IIopkins Esq against Kichard Marvin \& Sammel shaw for information \& complaint by them \& others made to Congress against the said Esek Hopkins while in the service of the Unitert States

lecolved that the reasonable expenses of defending the said suit be defrayed by the I nited states.

()rdered that the secretary of Congress furnish the petitioners with attested copies of the records of congress, so far as they relate to the appeintment of Esek Hopkins Iscp to any command in the continental navy and his dismision from the same, and also to the proceedings of Congress upon the complaint of the petitions against the sajcl lisek llopkins, presented to congress through the marine committee as mentioned in their petition." 
With this substantial backing and with the effect it produced the defendants came before the court for trial. Marvin and shaw secured for comnsel IVilliam Channing, Esq., of Newport, then attorney gente eral of the state. Ilopkins produced as witnesses to testify to his character and comduct men eminent in the community, men who had known him for years on shore and at sea: they were: Capt. Joseph ()lney; the Rev. James Manning, a Baptist clergyman, and at this time president of Rhode Island College; Captain Daniel Tillinghast. the Continental agent for Rhode Istand. Captain Ambrose Page, a sea captain, a member of the General Asembly of Rhode Island, and afterwards Judge of the Admiralty Court of Rhode lsland; and Stephen Potter.

The trial of this case occupied fre days. Captain Joseph Olney, the first witness for the plaintiff, was engaged, and in his examination testified:

"Question. Captain Olney, are you acquainted with Esek Hopkins Esq, character as a public officer $\&$ a private gentleman, if so please to relate his character.

Answer. When he commanded the fleet 
I always looked upon him as a commander always desirous to serve his country $\&$ in the fleet we looked upon him as a gentleman

Question. How long have you been acquainted with $\mathrm{Mr}$ Hopkins and what time did you enter the service on board the fleet which commodore Hopkins commanded.

Answer. I entered on board the fleet under his command at Philadelphia in December 1775 and remained there all the time he commanded it. My acquaintance with him has been from my youth up.

Question. Have you ever heard the conduct of commodore Hopkins as commander of the flect censured.

Answer. I have heard his conduct blamed by some in Philadelphia $\&$ in particular Mr Newman and Capt Shaw who left the fleet at New London.

Question. Have you heard that the public in general censured the conduct of Commodore Hopkins while he had the command of the fleet.

Answer. I have heard him censured but by them that I thought knew nothing of the affairs of the fleet.

Question. On board of what resiel was 


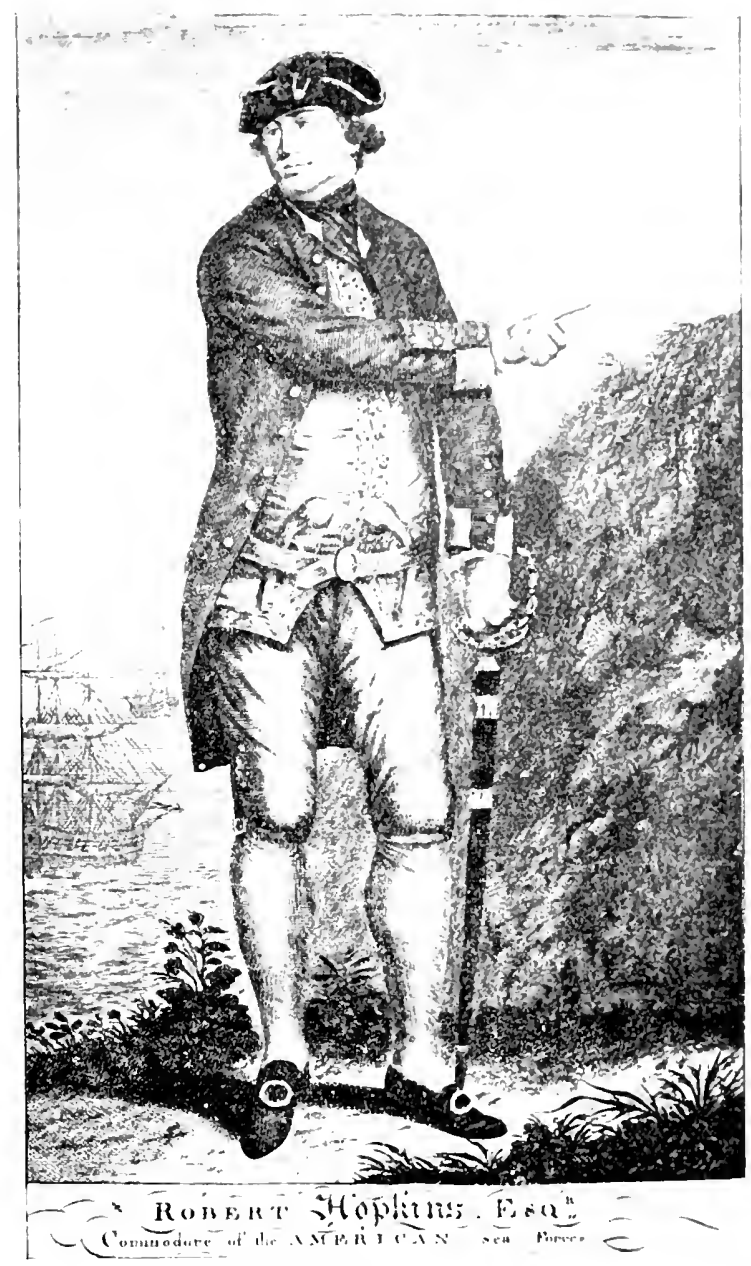




\section{.}


you an officer, and was you with the satid Esck Hopkins the whole of the time he had the command of the fleet.

Answer. I was Second lieutenant on board the 'Columbus' until he returned from Philadelphia, \& then was appointed to the command of the "Columbus' until January $177^{6 .}$

Question. Did you ever hear Esek Hop)kins Esc speak disrespectfully of the Congress or the Canse we are engaged in

Answer. No."

Rev. Dr. Manning was then sworn and examined, testifying in reply to the questions put to him as follows :

"Question. How long have you been acquainted with Esek Hopkins Esq \& what is his general character.

Answer. From more than seren years intimate acquaintance with said Esck II(p)kins Esq., I have had the highest reasons to esteem him a man of honor \& respectable character amongst mankind \& a zealous advocate for the cause $\&$ liberty of his country \& disposed to serve it with his best abilities.

Question. Have you ever heard the 15 
conduct of the said Esek Hopkins as commander of the fleet censured.

Answer. I have heard many say that he ought to have gone out with the fleet before the Enemy came to Newport, and others justified his bringing the Ships into the river. but whether they were qualified from personal knowledge of the state of the fleet, to form a judgment, I am not able to say.

Question. Are you acquainted with the conduct of the said Esek Hopkins Esq while on board the fleet.

Answer. No"

Daniel Tillinghast's testimony disclosed another point of the libel not heretofore mentioned in the case, and the insinuation that he had been irregular in his transactions with his men regarding prize money met a prompt denial. Tillinghast's testimony being as follows:

"Question. Are you acquainted with Commodore Hopkins \& for how long, and what is his general character as an officer, seaman and gentleman in private life.

Answer. I have been personally acquainted with Commodore Hopkins above 28 years \& have always () him to be an 
experienced officer $\&$ much of a gentleman in a private character.

Question. Did Commodore Hopkins receive the wages $\&$ prize money belonging to the seamen under his command in the fleet.

Answer. No.

Question. As the British fleet arrived in the river \& at Newport was the fleet under the command of commodore Hopkins fitted for sea, were they after the arrival of ( ) British fleet finished \& a considerable sum of money expended on them

Answer. I having a personal knowledge of the situation of the fleet at that time, know they could not proceed to sea, and a considerable sum of money was expended on the Ships after the fleet arrived.

Question. Did Commodore Hopkins ever call on you as Continental agent to pay off the seamen \& make division of the prize money.

Answer. He did \& I paid as long as I had any money in my hands.

Question. IO you conceive the conduct of commodore Hopkins to be any way detrimental to maning said fleet.

Answer. I did not. 
Question. What number of men had they on board the ship 'IVarru' \& the other ships.

Answer. To the best of my knowledge about 110 and but few seamen. among them on board the 'Warren'. on board the 'Providence' about roo. \& the 'Columbus' about 30. the Sloop 'Prowidence' about 15-

Question. Are you acquainted with the conduct of the said Esek Hopkins when on board the fleet. Did you ever hear his conduct censured by the public

Answer. As to his conduct while on board the fleet I never heard but he behaved as an experienced officer, nor was I on board to see his conduct. I have heard him censured often by people that I was sure did not know the situation of the fleet at that time"

The examination of Captain Ambrose Page, who had known Hopkins from his boyhood days, was of much the same character as that given by others and was submitted as follows:

"Question. Are you acquainted with the character of Commodore Hopkins as an officer, seaman and as a gentleman in private life, please to relate. 
Answer. I have known Capt Esek Hopkins Esq from his youth, until he commanded the American fleet, to my certain knowledge his character as an honest judicious commander ever has been esteemed amongst the gentlemen of this town. I have also known him in the 11 Indies on several voyages, where he was much respected by the merchants of my acquaint. ance, \& I doubt not but every gentleman will allow him, a sincere friend in the cause of his Country

Question. Did you ever hear the con. duct of the said Esek Hopkins Esq. as commander of the fleet, censured $\&$ by whom.

Answer. I do not particular remember, but some of the then present council did not justify his not going to sea on the expectation of the British fleet taking posiession of Newport.

Question. Are you acquainted with the conduct of Esek Hopkins Esq. while commander \& on board the fleet.

Answer. No.

Question. As you was one of the members of the upper house of Assembly when commodore Hopkins requested the advice of the Committee who acted in the recens of 
the General Assembly, what was to be done with the fleet under his command as the British fleet then a vast deal superior in numbers $\mathbb{S}$ force were approaching what was the answer given by Commodore Hopkins.

Answer. As near as I remember, was this. His orders was on his being fitted \& manned to go on a second expedition therefore could not proceed to Boston as we advised, but if he could take any measures to man his fleet; would immediately proceed to Sea "

In concluding the evidence in the case for the plaintiff Stephen Potter made the following deposition in open court:

"The deposition of Stephen Potter Esq duly sworn saith that he had been acquainted with Commodore Hopkins \& that he the Said Hopkins hath borne the character of an honest man as far as I ever knew or heard, \& I have been acquainted with him for near twenty years \& I never heard him charged with any thing criminal that disqualifies him in my opinion from serving in any station whatever. I have heard some persons fault him in some matters, that when they had done, I concluded they were not 
judges of : they were matters of his staying in Providence river with the flect."

The depo-itions of the three officers who had first warned Hopkins of the comspiracy were also submitted.

The defendants relied almost entirely for their cane upon the proceedings in Congress. Full copies of all the acts of Congress relative to Hopkins connections with the nary had been transmitted by the secretary of that body, as well as copies of letters from President John lancock and others, to the Commander: there were also the depositions of the officers and men on the "Iramen" who had signed the petition to Congrese against llopkins, as well an copies of the petition and complaint itself. In addition to the depositions of the officers of the "It amen" heretofore presented in the narration of the erents leading up to this point, there were submitted to the court those of Sellers, Marvin, Stilhman, Lothrop, Brewer and Truman, and, that an imprartial review of the case may be made, they are here griven.

These depositions accompanied the petition and complaint when it was first sent to Congress, and were as follows: 
"On Board the Ship 'Tharen'

$$
\text { February 23.1777. }
$$

The regard which I have for my country has induced me to write the following accusations against commodore Hopkins:

First. I know him to be a man of no principles \& quite unfit for the important trust reposed in him. I have often heard him curse the honorable Marine committee in the very words following 'God damn them. they are a pack of damned fools If I should follow their directions the whole country would be ruined. I am not going to follow their directions, by God.' Such profane swearing is his common conversation, in which respect, he sets a very wicked and detestable example both to his officers $\&$ men. 'Tis my humble opinion, that if he continues to have the command, all the officers who have any regard to their own characters will be obliged, very soon, to quit the service of their country. When the frigates were at Newport, before the British fleet took possession of that place, more than an hundred men who were discharged from the army, the most of them seamen, were willing to come on board the ships and assist in 
carrying them to Boston, or any other harbor to the Eastward, in order that they might be manned, but commodore Itopkins utterly refused, being determined to keep them in this state, from which we have not been able after all our pains to procure a single man for this ship. Ile has treated prisoners in a very unbecoming barbarous manner. His conduct and character are such, in this part of the comtry that I can see no prospect of the fleet ever being manned.

$$
\begin{aligned}
& \text { JA'S SEILERS." } \\
& \text { "Siml 'Harren' Feb. } 2+1777 .
\end{aligned}
$$

The following lines contain the reasons why we signed the petition against commodore Hopkins. Ire consider him on account of his real character, quite unfit for the important public station wherein he now pretends to act. We know him to be, from his conversation \& conduct, a man dentitute of the principles both of religion \& morality. We likewise know that he sets the most impious example both to his officers \& men by frequently profaning the name of Almighty God \& by ridiculing virtue. We know him to be one principal obstacle or reason why

\footnotetext{
'From a copy of the original laid before congress. See allas llophins l'apers, vol. 3. page 14
} 
this ship is not manned $\&$ people are afraid to engage in the fleet through fear of their being turned over to this ship. We have considered it as an indispensible duty we owe our country sincerely to petition the honorable Marine Committee, that his conduct \& character may be inquired into, for as things are now circumstanced we greatly fear these frigates will not be in a situation capable of doing America, any service

Richard Marvin

- George Stillinan

BarNabas Lothrop

Commodore Hopkins is very much blamed by people here for not destroying a British frigate when aground a few days ago in this river, and we suppose very justly

$$
\begin{gathered}
\text { Jas Sellers } \\
\text { Richid Marvin"1. } \\
\text { "Ship 'Warren' Feb 24, i777 }
\end{gathered}
$$

I the subscriber have heard commodore Hopkins say, that the Continental Congress was a pack of ignorant lawyers clerks $\mathcal{E}$ that they knew nothing at all. I also have heard him say, when earnestly persuaded to remove

\footnotetext{
"Ilopkins l'apers, vol. 3, page I4.
} 
the fleet to Boston, being in constant expectation that this river would be blocked up, The ships shall not go to Boston, by Gerel. JAMES BRIWIE" "Sine 'Ilarron' Feb 241777.

I the subseriber can attest that our commander Commodore Hopkins has spoken very abusively concerning the linnomble Congress calling that respectable assembly. who ought to be considered as the guardians of American liberty, a pack of ignorant lawyers clerks who know nothing at all

$$
\text { Johi Truan " }
$$

The result of this trial was unfavorable to Hopkins, for the jury, seren of whom were residents of Providence, after considering the evidence, brought in a verdict for "the defendants and their costs," thereby declaring that the defendants did not "wickedly maliciously and infamously conspire together in order to injure the plaintiff " Notwithstanding the prejudices and opposition there was against him, Hopkins did not lose the confidence or respect of the citizens of the state

Ilopkins lapers. vol. 3. patere 11.

Ibit. 
by this action of Congress and the fundings of a jury of his peers. If he had been the unprincipled person that has been pictured he would soon have disappeared from the stage of public life and never more have been heard of; public sentiment does not uphold such men; but the situation was well understood by the people of the state. They knew that he was being persecuted by a set of men whose influence was so powerful that it was wiser to disregard it than to antagonize it, and they kept their own counsel. Congress had revenged itself on the man who had spoken carelessly of it, and Hopkins had been told by twe tve of his fellow men that no injury to his reputation or character had accrued by reason of the allegations made against him. Thus ended his troubles brought about by his connection with the American Navy, but it did not end his connection with the cause in which the colonies were then desperately engaged. Public conficlence in him was not lessened, and upon retiring from his command he at once enlisted heart and soul in the public service in other fields of usefulness. 


\section{CH.MPER VH}

CIOSIX) YEALS.

I was on the second day of January, $17-5$.
that Hopkins was dismisied from the naval service of the United States, and a career which promised much at the outset came to an end.

It was not in his nature, however, to remain inactive. His enemies had triumphed, surely, but he was not without friends. His townsmen recognized his abilities and his patriotic motives too, and at the spring election following his dismissal from the naval service he was again elected a deputy to the cieneral Assembly from the town of North Providence, which he represented from 177 to 1786 . The situation in Rhode Island during a portion of this period was most critical. The British forces held ponsession of Newport, and the lower bay was patrolled by british war vessels. Marauding partices from the enemy's camp, frequently desended upon the bay side towns, and a state of 
warfare existed which kept the people constantly on the alert, and the militia of the state continually under arms.

Soon after Hopkins took his seat in the legislature that body appointed him a member of the Council of Nar, and this position he held during the entire period of its service.

During the years of the war he was frequently employed on various committees having the charge of military affairs. Particularly was he active on committees appointed to adjust the accounts of the several regiments of the state, and as late as I 79 I, some vears after his services in the legislature had terminated, he was appointed, with Benjamin Bourn, to examine and adjust the claim of General 
Ezekiel Cornell for his services during the years of the Revolutionary struggle. While a member of the General Assembly, in 17.55 , he was elected Collector of 1 mposts for the county of Providence, and held this office for one year.

It was in this year also that Ilopkins' distinguished brother, Stephen, elosed his career, full of years and honors. He had been in public life for more than forty years, and no man had attained a wider reputation in the colonies than Stephen Hopkins of Rhode Island.' His influence was powerful from the very beginning of the struggle for American Independence. Of all the delegates in the Continental Congress none inspired greater respect, was so closely followed in debate or was so highly valued for his opinions as Stephen Hopkins; yet, after he had left that body, and at the moment when all these influences were so necessary to the future of Esek Ilopkins, he was powerless to extend any assistance. Esek Hopkins undoubtedly owed much to the influence of his brother, not only in official preferment but

${ }^{1}$ For an exhaustive stuly of his life and charater see "stephen llopkins, a Rhode lsland stateman, ly William E. Foster. l'rovidence, sidney S. Kicles, In 4 ." 
in the example set of patriotic duty to his country and unselfish service to his fellow men.

It was his privilege during the last year of his service in the legislature to nominate the Rer. James Manning to represent Rhode Island in the Continental Congress, and he was elected to that body, where he served one year. Manning at this time was president of Rhode Island College, and the two men had strong attachments for each other.

Esek Hopkins had attained the ripe age of seventy-three years before his public career terminated. For more than thirty years he had served in various public stations, and the regularity with which he had been chosen to represent his town and state is the strongest evidence of his ability, honesty and integrity in all his dealings.

Not only had he been called upon to give of his talents and his time in managing the affairs of government of the state of his birth, but his wise counsel had been recognized by the institution of learning which had been established in Providence a few years before, and in 1782 he was elected one of the trustees of Rhode Island college, afterwards 
Brown University, which position he held at the sime of his death. Imomer the stuclents in the colleges solatuating in the clase of I - S7, was fomathan Maxey, al goumg man from Atteboro, Mass. The sane veat Masey became a tutor in the university. and served until 179, when he was chonem pastor of the lirst baptist Chureh, and in August of that year married Iopkins daughter, Susimnah. He subsequently was elected president of the college and had a distinguished career.

Heart Hopkins, another daughter, was a woman of great culture, and, quite in aldvance of the period, iook the regular course of study at the college, under the special direction of her brother-in-law, its president.

About this time the afflictions of old age began to creep upon Hopkins; he partially lost the use of his limbs in "comsequence of a paralytic stroke," so that he was obliged to go about on crutches. On the fifth of December, I 796, he was still further afflicted by the death of his olclest son, Captain John Burroughs Hopkins, who had served sogallantly with him in the Nay.

Commected with the fecbleness of old ane 16 
there is an incident so touching that it arouses our sympathies and brings vividly before us the heart aches and sufferings of this venerable man. It will be remembered that during the proceedings in Congress against Hopkins no one took so firm a stand in his defence as did John Adams. We recall the scene between Milliam Ellery and Adams when, at the close of the debate. Ellery advanced to the seat of Adams, and, giving him his hand, thanked him for his final plea in behalf of the Commander, and also said: "You have made the old man your friend for life; be will hear of your defence of him and he never forgets a kindness."

Years went by and Adams was called to the highest office in the grift of the people of the new nation. No one watched his advancement with greater interest or felt a deeper pride and satisfaction than Esek Hopkins. 'To him Adams stood out distinct and apart from all other men in the whole land, the embodiment of manliness and honesty. In the time of adversity he had been Hopkins' friend; not such a friend as is secured by the enthusiasm of political strife, but a friend, carnest and sincere, deter- 


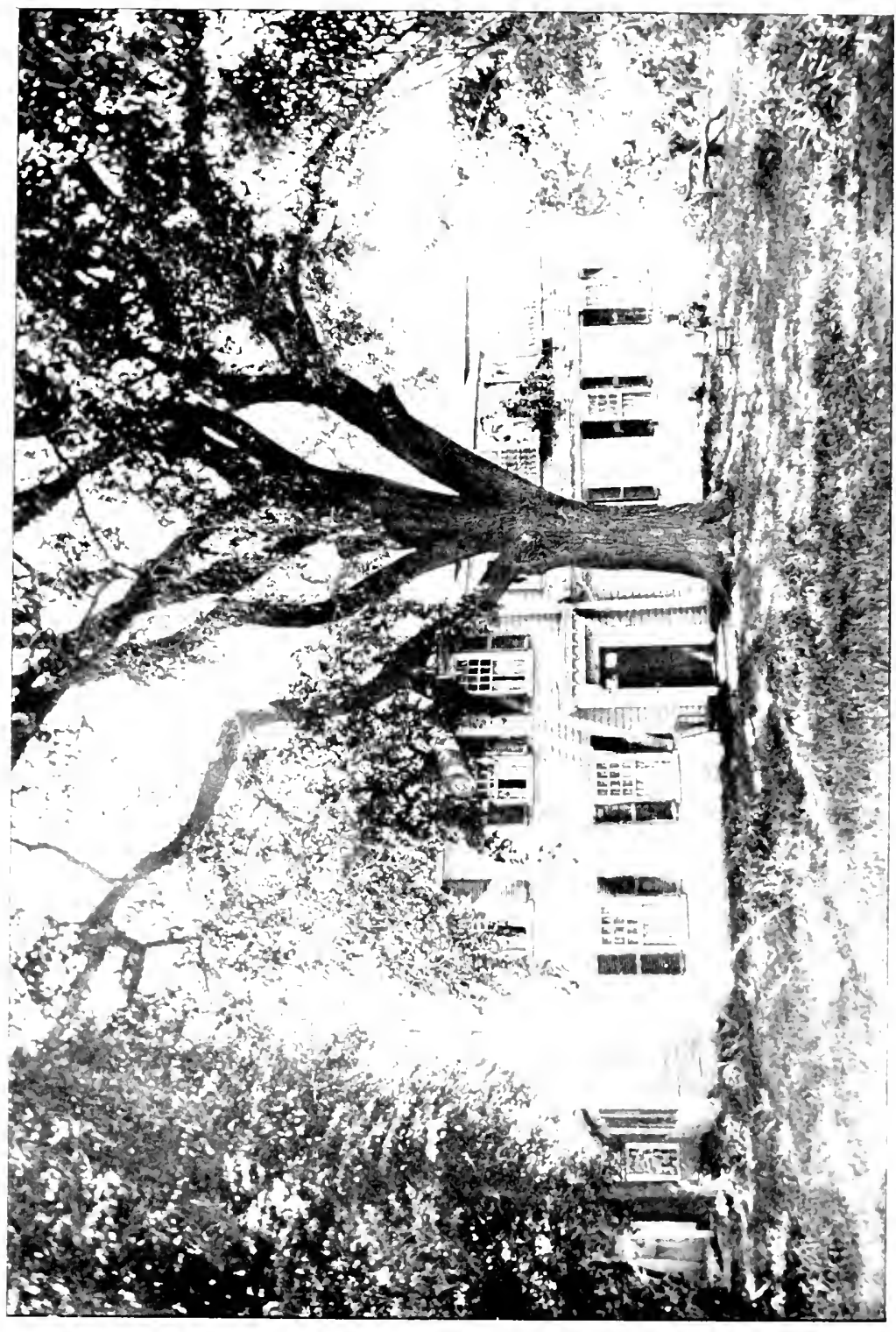



mined to know the truth and base his whole judgment upon it. In the summer of 1797 John Adams, with his family, stopped in Providence on his way to his Massachunets home. It was the first oppertunity that had been offered to the citizens of the town to pay their renpects to him since he had been elected to the presideney, and great preparattions were made to honor the distinguished guest. The president was esererted inte the wown by the Providence l.ight Dragen-at company which had been formed some years before, and his arrisal was signalled by the ringing of bells and the roar of cannon. Ile was escorted to the colden ball tavern. where accommodations had been morided for himself and family. "In the erenings the College edifice and some private dwellings were brilliantly illuminated and the whole town put on a sala appearance. That night, while the president was resting in his room with his family, he was informed that a gentleman wished to see hims. Leasing them lie went to sne of the wating rooms and there found an old man bowed with gears and infomities It was lisck Hopkins. In his fecble condition he had been driven to the inn that he might show 
his respect and express his gratitude to the man who, years before, had stood up for him in the hour of trouble. Propped up by his crutches, his eyes overflowing with tears and his heart filled with emotion, he thanked the president for his interest taken in defending him from the attacks of his enemies.

This episode made a deep impression upon Adams, and he detailed the occurrence in the diary of the events of that journey, and afterwards wrote as he recalled the pathetic scene that Hopkins said: "he knew not for what end he was continued in life, unless it were to punish his friends or teach his children and grandchildren to respect me," and Adams further adds: "The president of Rhode Island College who had married his (Hopkins) daughter and all his family showed me the same affectionate attachment."

'There was a social side to Esek Hopkins' character that was as pronounced as it was interesting and attractive. He was fond of the companionship of young people, and at all social functions of his friends and neighbors he was a conspicuous figure. He is said to have danced well, was bright and entertaining in conversation, and his company was always enjoyed on account of all these 
attractive qualities. No party, ball, or similas gathering was thought to be complete without his pesence, and only when imporstant engagements or ill health prevented did he fail to be numbered among the guests. As he adranced in years, and sicknens prevented him from taking part in any such pleasures, it becante a source of much disilppointment to him. For a lomg time previous to his death he was comfuned to his bed, unable to move, yet possersed of all his faculties and exhibiting a keen interest in all that was going on about him.

The last days of his life were attended with much suffering, yet he calmly awaited the end with marked patience and quiset resignation. ()n the evening of Fiday, licbruary 26, sor, the long and uneful life of this vencrable man came to an end. On the following 'Tuesday ( March 2 l his body was borne to the little ciod's Acre on the homestead farm, followed by a large number of "affectionate relatires and friends."

l lis death was monroned by the people of the state, to whom he had become endeared by his years of active public service. Some idea of the entimation in which he was held by his fellow men may be derived from the 
following announcement of his death, published in the Providence Gazette, on March 6, ISO2:

"On Friday the 26th ult. at his residence in North Providence, Esek Hopkins, Esq.; in the sfth year of his age. His remains were on Tuesday last followed to the grave by a respectable concourse of affectionate relatives and friends. Through the different stages of a long life, the character of this gentleman was uniformly distinguished by an energetic mind, and a steadiness of principle, which age and infirmity were unable to impair. A genuine fortitude of mind, a lively sensibility of heart, and an immorable adherence to integrity were his general characteristics. With patience and resignation he continued to sustain the afflictions of disease, till he calmly resigned his life, while the agonies of death could not extort a groan. In him his children have lost an affectionate parent, society a worthy nember and his country an inflexible patriot. In the American Revolution, he stood forth in the perils and hardships of war. He was honored with the command of the first naval expedition equipped by the Continental Congress, and was the first who dared to unfurl the American 
thas in defiance of a powerful foce The duties of many important offeren were by his fellow citizens confided to him, of which he. acquitted himself with reputation and al,ilits. In the leegislature of the state he long sustained a seat, and was a member thereof at the time of the adoption of the federal constitution, which he then stremuonsly advocated. and has uniformly continued to support."

(of the ten children born to Eack and besire Hopkins, five were soms and five daughters; all of his sons died before him. while all the daughters survived their father.

On the fifteenth of September previoun to his death Mopkins executed his will, generously remembering his children and arand. children and amply providing for their future welfare. He left little personal entate, which consisted mostly of houschold furniture, cattle

The ten children of lisek and besire llopkins were:

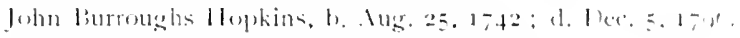

lleart, i. sept. 1, 174ti d. July 11, 1,25.

Abigail, b. Act. 25,1746; 1. April 25. 1 22

samuel, b. feles 19, 17ft; 1. Sept. 22, 1750.

Amey, b. Jan. 20. 1751; (1. 1)ec. 14, 19:5.

stephen, b. March 6, 1753; il. July $317-01$.

-usamma, b. Nay 16, 1750; 4. _- 1403.

Jsek, b. June (1) 1755: d. - 1777.

samuel, b. - 1. 1)er. 17-2.

Desire, b. May 17, 1764; d. May 20, I 43. 
and farm implements, but his holdings of real estate covered more than two hundred acres in the neighborhood of his homentead. To his three daughters, Heart, Desire and Susanna, he bequeathed the man-ion house where he had lived so long. This house is situated in Providence on Admiral street, named in Hopkins honor many years ago. It still remains in the possession of one of his descendants, being now owned by Mrs. Frederick L. Gould, of Cambridge. Massachusetts, a great great granddaughter.

Originally it was a two story gambrel roof house, not an elaborate or imposing structure, but from time to time additions have been made until now it is full of quaint corners and little ells. The old well, with its substantial well house in the rear of the kitchen, yet supplies water for the household as clear and sparkling as it was when Esek Hopkins first came there to dwell. Nearly a mile away to the northward is the graveyard where the remains of the distinguished Commander lie buried with others of his kindred. This tract of land, or as it was called, "the burying place," was conveyed to the town 


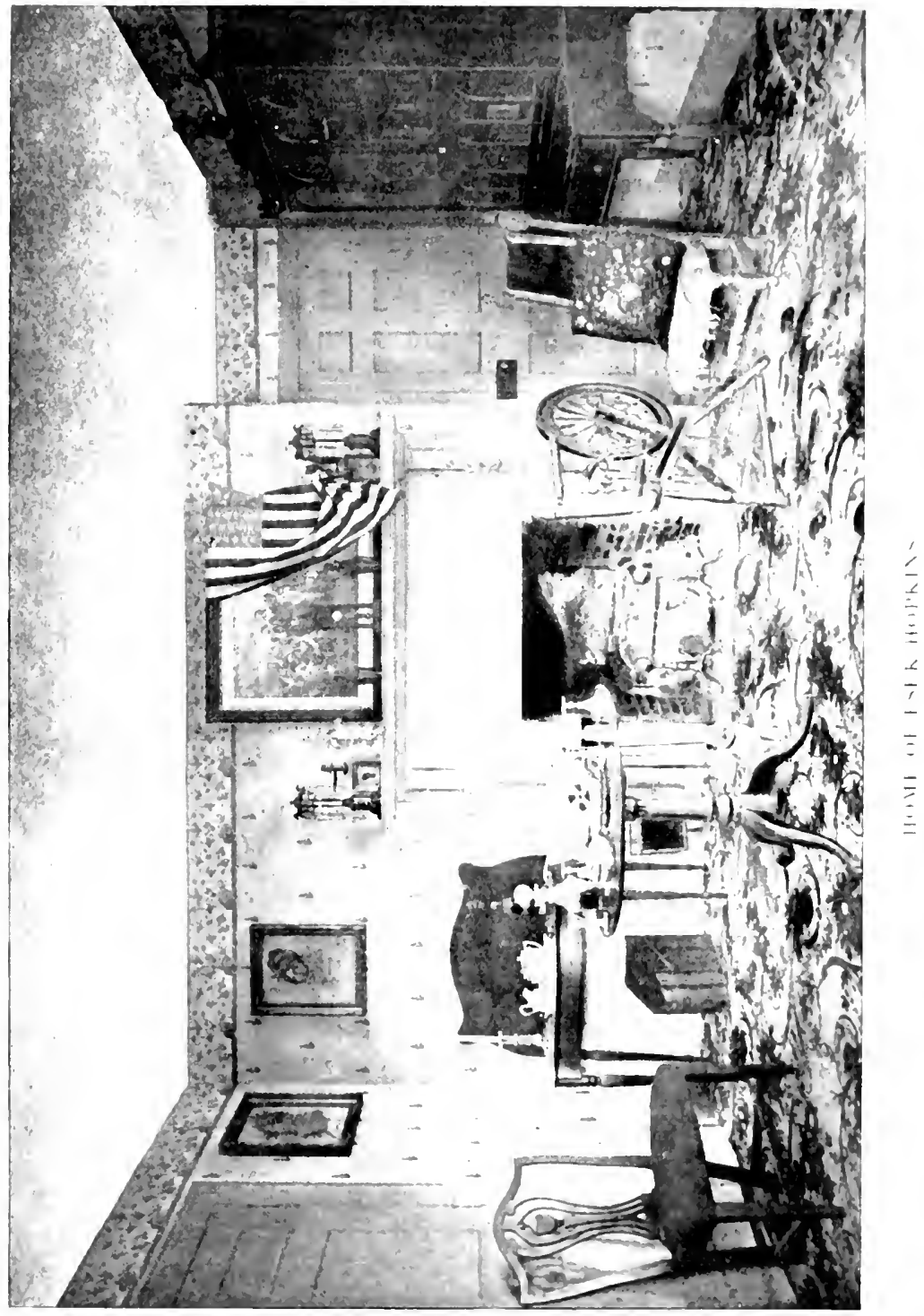



of North Providence by linek I fopkina, on september 20, 1791, "for a burying place. for that use only." When a part of North Providence was annexed to the city of Providence this burying wround was boredght within the city limits and is now known as "I Iopkins" Park," proceedings having been taken by the municipality tomards thi end. A bronze figure, heroic size has been reared over his grave through the liberality of a de. scendant and the municipality, representing the Commander in his miform of the nary. On the pedestal is inscribed this legend. prepared by the author of this work:

\section{ESEK IUUKIXS}

CoMMANHEK IN CIIL:

(1): TIIE

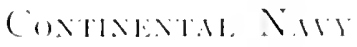

I)IRING; THE:

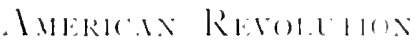

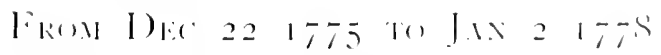

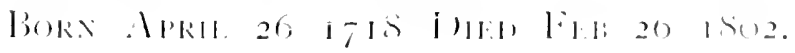


It is doubtful if there was any more experienced seaman or skilful navigator to be found in any of the colonies at the outbreak of the American Revolution than Esek Hopkins. He was then a man of mature years, had commanded ships for more than thirty years, comprising merchantmen and privateers, and no American ship master was better known in foreign parts. It is not too much to say that there were other ship masters who possessed similar capabilities, were skillful navigators and brave seamen. It was not these qualifications alone that caused Esek Hopkins to be selected to command the navy of the united colonies.

The material from which to select such a commander and even officers for a navy list was scant indeed. With the organization of a naval service a new system and order from that hitherto in rogue on ressels was demanded, a discipline strict, almost severe, was imperative.

The ship master of that period, as now, was an autocrat on board his vessel, but there was little distinction between the relationship of officers and men. The forecastle and quarter-deck mingled in the most friendly manner. 
The officers and seamen were intimate friends, neighbors, or associates at home, and on ship board continued the intimacy. There was a discipline peculiar to the sea which was furm and unyielding, but it was not such as was expected on a govermment ship.

When a nary was projected this element in its composition was a subject of much concern; the colonies never had carried on naval affairs to any extent. A certain experience might have been had by the men who had served on the colony coast guard ships, but the life on these quasi government ressels was more free and easy, if any thing, than that aboard the merehantmen and privateers.

Even with the military forces in the colonies the same difficulty existed only to a lesser degree. From the earliest days of the settlements in America a military force had been essential to the life of the colonists.

Trainings had been instituted, and were followed up with strict regularity; a certain proficiency in tactics and discipline had been accomplished, and even some active experience in the field had been obtained in the Colonial wars. But with even this experience, when the military force of the 
colonies was called into the field there was a decided lack of military methods. Discipline, too, was lax, the officers were selected with due regard to their experience and capabilities, but the fact that they were popular with the men and companionable fellows had great weight in securing their appointments. This relationship was continued in the camp and field, and officers and men met on a common level. This being the state of the military force, with years of organization, it was important that in organizing a naval force that some one skilled as a master mariner and possessed of a sufficient knowledge of discipline and the govermment of a body of men should be selected.

Of all the available men for the command of the navy, none, it was considered, combined so many qualifications as Esek Hopkins; at the moment of his selection he was in command of a brigade of militia and conducting delicate negotiations with the enemy. His appointment to the position was a distinguished honor, but it was an honor which it would have been far better for him to have refused, and accepted one less important. His lack of success in the position was not entirely owing to himself; he was a victim of 


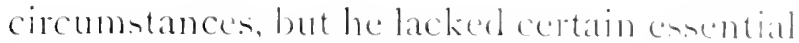
qualities that comstitute a commanders.

Cooper has well said: "There was melack of competent matigators of of brave seamen, but the high moral pualities which are indie pensable to the aceomplished offecer are hardly to be expected among those who hare received all their training in the rude and imperfect school of the merchant serrice."

At this period there was no regularity uf system and no standard of discipline in the nayy. "The irregularities of the semice, it is true," says Cooper" "grew out of the exigencies of the times, but their evils were incalculable. Rank, that great sourec of contention in all services in which it is not clearly defined and rigidly regulated, appera to have created endless heart burnings. 'The dissensions of the officers, naturally communicated themselves to the men; and, in time. this difficulty was added to the others which existed in obtaining crems." "They ale jealous of him" alleged Chaplain Recel, in his complaint against Hopkins to the Marine Committee, and he somnded the key note in the whole miscrable plut when he subscribed his name to these words. Combined with the jealousy of the officers in the tlect. and 
the revengeful spirit that pervaded the minds of those men outside, together with the petty politics that pervaded the Continental Congress during the earlier period of the war, there was fuel enough to start a fire which no one could tell what it would consume before it was quenched.

The moral status of the nary in its early days undoubtedly was not of the highest. The rules of the service provided for a chaplain, but it was not until long after the nary was organized that such an officer was enrolled. The first to be appointed was John Reed, and he seems to have been more willing to lend his influence to underhand methods against his superiors than to pursue a course more in keeping with his profession. Some light is thrown upon this condition of the nary and the character of the men who were so fearful of the "strange oaths" of the Commander, by the following letter which Hopkins wrote to the Reverend Samuel Hopkins, of Newport:

"I received yours of the soth September yenterday, and am very much obliged to you for your address and advice; and as to your complaints of the people belonging to the nay, I am now to let you know that I did 
not enter into the nayy as a livine and that I am not qualified to act or give directions in that matter. The Congress whom I serve, made provision for a chaplain to perform that necessary duty, but to my mortification I have not been able to get a single man to act in that character, although I have applied to many. If you know of any one that has the good will of mankind at heart sufficiently to expose himself to necesary danger of that service, should be slad if you would send him, who you may depend will be treated with due respect: and if none can be proscured. I cammot but condole with you the depravity of the times."

This letter, too, shows in a measure a condition which, it cannot be denied, was all tox conspicuns in the service during the peried of which I write. There was mot that "high feeling of personal pride and self respect that create an csprit de corps and the moral courage and lofty sentiments that cone in time to teach the trained offecer to believe any misfortune preferable to professional disgrace." No more brave, patriotic, and skillful body of men could be foumel in the colonies than those who formed the naval list, but those highly essential qualities were 
decidedly lacking, nor could they be expected; the fault was not altogether theirs, it was a condition of the times.

There can be no doubt but that Hopkins was reckless in his speech. The mariner of that period was often more expressive than polite in his conversation, and profanity on ship board as well as elsewhere was not uncommon. In this connection I am reminded of the story of the Scotch deacon who made a voyage with one of the members of his church, a bluff old sea captain. One day a terrible storm came on and all hands were called upon to work ship. In the excitement and danger of the moment this old captain used certain language which greatly astonished the good deacon. He, however, said nothing, but when the ship, after a successful voyage, dropped anchor in her home port, the deacon lost no time in reporting to the elders the language which the captain had used during the storm at sea. In due time the captain was called before the church and charged with profane language-the deacon reporting what was said. This bluff old sea-dog opened his eyes with astonishment and replied: "Bless you, that wasn't swearing! If I didn't talk that way in a 


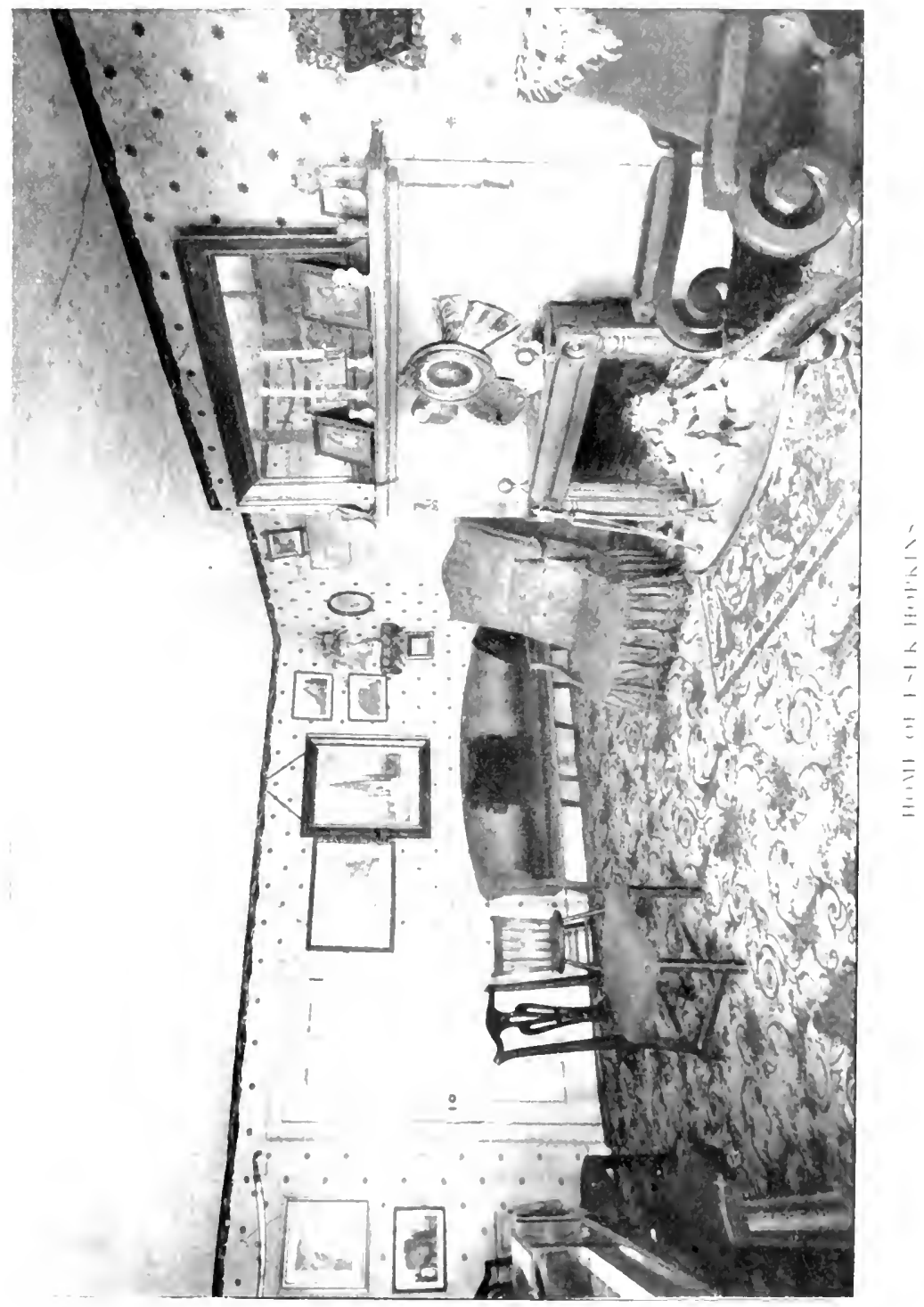



storm, the sailors would think I didn't know my business." And it is related that this argument secured an unanimous acquittal. Hopkins no doubt had spoken carelessly of the men who were controlling the affairs of the navy, and it cannot be denied that that exercise of authority was often meddlesome and irritating if not disere spectful and insulting.

A careful examination of the charges and depositions against him will show that there is nothing in them that can be criticised exeept those alleged words of disrespect. But an officer who so far forgets himself as to use language disrespectful to his superiors incurs a liability which may seriously affect his whole future, and so it did with Hopkins.

This failing on the part of Hopkins was used to great disadrantage to him. It furnished excellent material for his enemien to base their attacks upon, and, in the hands of the men who were behind this whole miserable conspiracy, was used with telling effect. There certainly is a vein of humor in the statements malle by thene petty officers that "we know him to be one principal obstacle or reason why this ship) ("I (arren") is not manned se peeple are afraid to engage 
in the fleet through fear of their being turned over to this ship." The idea of sailors being afraid to ship aboard of a vessel whose commander used strong language is a unique one in marine circles. Hopkins never was charged with the abuse of his men; he abused himself the most, and if there had been the slightest grounds for this charge they would have certainly taken advantage of such a condition.

In his encounter with the stranded frigate "Diamond" there appears little to criticise, except, perhaps, his attempting an attack on her in a small sloop, which was a piece of bravado more censurable than his neglect to do so with his ships. Below the "Diamond," not more than six or seven miles distant, was a fleet of British war vessels riding at anchor in Newport harbor; almost under the guns of the "Diamond" was another English ressel riding on the water with her "anchor a peak." With a strong west wind it would have been possible for the British fleet, upon receiving a signal from the vessel lying near Patience Island, to have got under weigh and arrived at the scene of action long before the American ships lying up the river could have found their way through the tortuous 
channel southward in the face of this stronge wenterly gale. The "Diamond" Wats ats safe from the attacks of the American reasels. even though she was stranded on an island in the bay, as she would have been in Newport harbor under the gums of the whole British fleet.

It was an easy matter to charge him with neglecting to capture a stranded ressel, Inut when the circumstances are taken into consideration it will be seen that howerer much Hopkins might have lesired to accomplinh this, there was no hope of doing so with the prevailing wind. But there are grounds for the belief that the stranding of the "Diamond," almost under the gums of a sister frigate, was but a ruse to lure llopkins with his ships down the river, when a superior force of the enemy would surdenly appear and destroy them before they could beat up the winding channel to a safe anchorage at Providence.

No one knew his limitations better than Hoplins did himself. Repeatedly we find him writing to his brother and others in Congress: "Whenever you or the Comgres. hink you can get a man in my rom that will be of more service to the caune than I 
can you have my leave, and in justice to the Country I think you ought to do it; " at another time he pleaded his years.

If he had promptly resigned his command he might have avoided the complications which ensued, but such would have been cowardy, and no such impulse found a place in his heart. He knew that he was becoming entangled in difficulties, and that there was little hope for him to escape, yet he had pledged his life and his honor in a cause which he loved and to which he was devoted, and if, in the struggle, he fell, it would be in the discharge of his duty.

On the twenty-fourth of June, i 865 , the town of North Providence celebrated the one hundreth anniversary of its corporate existence. On this occasion the Reverend Massena Goodrich delivered a scholarly historical adchess, in which he referred to the men of the town who had achieved eminence in the nation's history, and used these words -a fitting tribute to a loyal son: "Of those whose homes were in this town, and who did bold service during the Revolutionary war, the name of Commodore Hopkins stands eminent. 'Though born in another town, he made for years this place his abode, and 


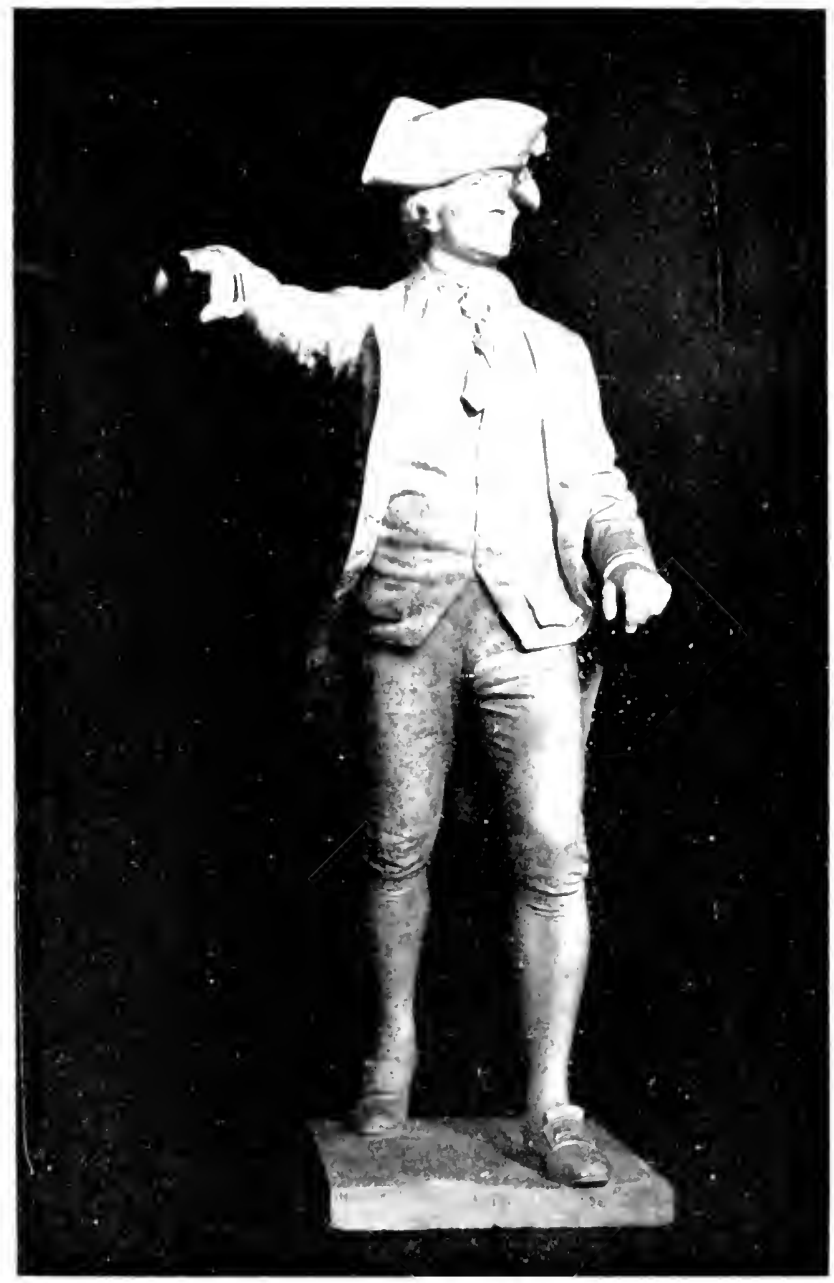

$-1111+1,1+-1$ h 11, 1 t

11111 

his ashes are mouldering within its bonders. It were superfluous to pratie him. Ilic valor is a part of the heroic heritage of his native State. Ilis name and lerry's, who alike, in different wars, upheld the homor of cur country on the sea, have given our little commonwealth cause to ghory in her naval warriors. for between two and theee years I lopkins was commander-in-chief of the nays. but the bitter sectional feeling in Congress. which operated so much on many an recasion to the disparagement of New England men, funally succeeded in ousting him from his honorable position. but by this act our country suffered most." 
APPENDIX 


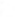




\section{PORTRATS OF FSEK HoPKINS.}

There are sesen known portratito of linek 1 lopkinn, the earliest being included in a group painted by foln (ireenwood, about the sear 1750, and in problatby the only life portrat extant. I full deneription of this painting, and the circumstances under which it was painted, will be found, with a photograveur represduction of it, at page $2 S$.

A mezzotint portarit of Itopkins, publisbed on l.ondon, by Thomas Hart, Esig., August 22, 176 , bearing the title " commodore llopkins (ommander in chief of the American lilect Publish'd an the act directs 22 Aug 1776 ly "Thos llart," is the beat known of the Ilopkins portraits, and hats frepuently been copied. This portrait was evelently produced to satisfy the demand for a likeness of the person who had so suddenly sprung into fame, for llopkins had already become a naval hero. It is puite likely an imaginary picture, for Hopkins conlel not have been in fondon, or in lingland for that matter, for mere than a year previous to its publication, and previons to this time he would have attracted wo more attention than a hundred other sea captains. (ieneral Henry kow pictures Hopkins appearance within at few weeks of the time when the llart portratit was published, and describes him as "an antiquated tigure" (see page 13.t), which the portrait dees noe confirm. 
The author ventures the opinion that but few of the engraved portraits of celebrities of the Revolution were likenesses of the person they purported to portray. They were produced to satify a popular demand. As evidence of this compare this Portrait Plate I with the following in "Narrative and Critical History of America," Winsor, Vol. VI.

Israel Putnam, page 192, which is reproduced from an engraving published by C. Shepard, 9 September, 1775 , probably in London.

Benedict Arnold, page 223; a mezzotint of this was published in London, in 1776 , the same year as the Hart mezzotint.

Benedict Arnold, page 448 ; this appears in "Geschichte der Kriege, in und ausser Europa, Eilfter Theil, Nürnbers, r 7 S." Compare also with Portrait Plate 2. John Sullivan, page 637 ; this was also published in London, August 22, 1776, from which the copy in "Geschichte der Kriege" is made.

A print bearing the title "Commodore Hopkins Commander en chef der Armej: Flotte" Portrait Plate 2 is in "Geschichte der Kriege," 1778 ; it is evidently copied from the Hart portrait with material changes in the background.

A rare print is in possession of the Rhode Island Historical society, volume of portraits, page 90, a copy of which is Portrait Plate 3 . This is also the Hart portrait, whthout the background of ships. It is inscribed "Hopkins Commandant en chef la flotte Americaine." Beneath the ellipse, within which is the portrait, are representations of the two flags associated with early Revolutionary history, the one bearing the injunction "I)on't tread upon me," the other, "Liberty Tree. An appeal to God ;" scrolls, 


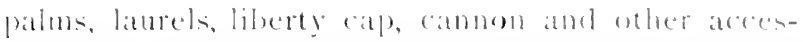
sories, form a fanciful boreler for the portrate Xo information is obtatmed relative to the origin of this portrait.

Winsor, in "Xartative and critical llintory of Imerica, Vol, V1, prage 570, note," mentions a port-

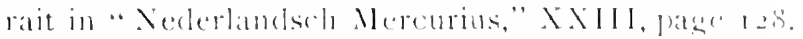
An extemeled search has fated to diselene a copye of this perioflical. Portrate Plate s maty be this louteh pertrat. If mot, then another is ateded to this interestime collection of 1 Iopkins purtrats.

A far different portrait of llopkins from thene is in "Muray's lmpartial llistory of the Amerioum War" (Vol. 11), a copy of which is l'ortran l'late $t$ : it beats the tiale " commolore llopkins." It wats engraved for "Murray's llistory of the American IIar." by R. Pollarl, and " l'rinted for 'T. Kobson New Castle apon Tyne." Mr. Pollard is porbably responsible for the features depicted.

A ludicrous full lenght portrate aceompanies ". In Impartial History of the II at in . Imerical between Great Britato and her colonjes from its commencement th the end of the year $1779 ; "$ london, printed

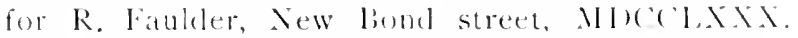
This portrat hears the title "Rohert IIphins, ('m-

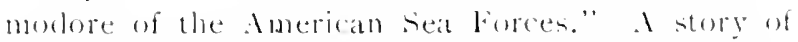
llopkin's life is contatined in this volume which doubtlese originated in the brain of the anthor of it. . 11 . Lherein contained may, bowever, have happened to Robert llopkins, whocer be may have been, but certainly it boes not refer a Esek IJopkins. This story is contaned in Aimmal l'reble's "Esck llop-

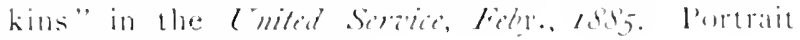
Plate 5 is a copy of this. 
An oil portrait of Hopkins is in Sayles' Nemorial Hall, Brown University, Providence, painted by Thomas I. Heade. It was copied in the early part of the present century from the Hart mezzotint. Heade was a painter of renown in Providence, and numerous portraits testify to his ability and professional skill. A copy of this, Portrait Plate 6 , is used as a fontispiece to this work. 
I NDEX 



\section{NIIEX}

Mraceo, 101, 105, 100, 113.

deams. Juhn, $72,73,75,70,77$. $\therefore 3,157,158,151,100$, $2+2,2+3,2+4$

Sambel, 72.73 .101

Alamson. lisbert, 207, 213.

Almiral street, $2+6$.

Alamm, battle of 31

Allees, folm, (:ipt.. 2os.

Alexandier, Mr., gi.

l'hilip, 107.

"Alfred." =-19, 10, 110, 115 $119,121,124,131,133$, $134,139.139,164,176$, $1,7,203$.

Ammiden, llailip, (itpt., $2(x)$.

" Andrea lourla." s3, los. 122. 134. $135,177$.

Angell, Thoman, 2.

Anthony. Ioseph. Eog.

Antigua, i2t. 127.

Antonio Joneph, 13.

"Arialne." 17.

Irnold, lienerlict. 3. $26,6$.

kibulen, - o.

llilliam, 3.

Arwin, libmats, I 7 .

Ash, lawrence, fots.

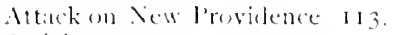

Attebors, $2+1$.

Avery, Juhn, Ir. 125.

liahamas. 11, 127, 133, 1+1. $157,16,2$.

liaker, I'. N.. (apt. . 20u.

$$
\text { (iaj)t. 2(x). }
$$

liald llearl. 104.

baptist, Mlexaluder, 1 s.

biarker, Jsaac, 2us. liamstable, (1) 1),

liarnwell, Jolin, $\cdots$.

biarton, 11 illiam. 24.

liatlett, lomiah, :ts.

bityes, lhomat, fot.

liecears, lianiel, las.

beeknam, bianame, "

liermudat on

lievin, livan, an.

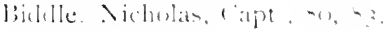
$15 ;$

libalicatri, I I

" likate l'rince," -2.

lilent leland (1):matel, 11s.

lisann, 11 illiam, 10\%.

" biciton,"121).

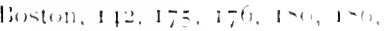
197. $230,233.235$.

liker, 31.

liman. lienjamin, 23".

busel1, (is) lalue 140.

liowles. John, 139.

linimant lames, 139.

Brecel, Janeph. Iots.

lifewer, James, 1-1, Int, 115, $221,231,235$

Brilgesater, $100,1=7,197$.

liristul, 111

- Limmlarded. =13.

british flect withdraws from \ewport. 130

bitle fienge, t21.

lawwn, dlen, 1apt, 171, 172. filistar, 1). 11 . fohn, 11, 33, 22, 1fe, 200. f(meple 1aic) $1 . f^{6}$. IIontfored, $115,117$.

Nones, 11, 13. 
Brown, Nicholas, 1 fo.

l'hilip. 207.

(niversity, $2+1,269$.

lirownel. samiel, 109.

Burroushs, lesire. 8.

Fizekiel. 5. 50, 100.

linckley, charles, 107.

liurke. Edward. 207.

“(abot," I0, I13, II 9,120, 121, 122, 123, 124, 131. $133,135,136,137,135$, $16+1,176,179$.

cambridge, 24 .

1 anada $6=$

Cape lear, 164.

Kiver, 164.

Henlopen, ioo.

Capes of l relaware, 100.

Carey, lirank, so7

Carpenter, Weden, Iof.

Cashinbers, l'eter, 135

tattell, lienjamin. 58 .

William, 88.

"Ceres," I 77.

Chadwick, John, so6.

ruacco. 106.

Channing, William, 223.

Chapin, Abigall, (l'erry), 207.

Ebenezer, 207.

Seth, 207. 205, 200.

Charles. Thomas, I 35.

Charleston, 89. 97, 109, 1\%

Chase, llachesan, Iof.

samuel, $; 2$.

Checkley. John, Rer., 19.

Chesapeak lay, 95.

Chopomisk, 6 .

Clarke. John Innes, 106, 146

Clark, Thomas, 138.

Thomas, cenwor, I 38 .

Coates. John, 137.

Coddington, Willan, 51.

(Cogrgeshall, Harriet X. 11.249 .

(ole. fohn, 26.

"Columbus." $82,109,121,122$. $129130,134,139,164$. $160,177,201,225.229$.

fommittee to builel ships secure officters, Iso.
Conanicut lstand, 66, 168.

Connecticut, 72.

Connor, John, 133.

Cooke, John. Io6.

Nathaniell. services during Revolution, 109, 110.

Xicholas $9,25,30 \mathrm{tt}$, $64.64,79,81,110,14^{6}$. 156 ; requests regiment to lefend lihode Island, 79: requests the service of (ieneral Charles l.ee, 79

Cooper. $1+4.253$.

fornell, Ezekiel. 239.

court martial, Abraham Whipple demands. I 33.

Cragin, sanuel. Capt.. 208, 209

(randale, christopher, 106.

"cruiser." I6t.

Curtis, John, 121, 139 .

c ushing, Edward I.. 29.

Darby, Thomas, I3s

ivilliam, 100

l)artmouth, 133, 150, 156, 197.

lashield. Lavin, I07.

l)aye, Keuben, 106.

leane, silas, $72,73,74,83,57$, 92,97 .

Debate over proposition for a navy. 72 .

l)elaware, $155,1,8$.

bate, $17 \%$.

river, $1+1$.

Dent, John, 109.

Inevoli, silas, 207.

lexter, Abigail, 4.

iresory, 4.

stephen, 4.

"I Jiamond," 172, 173, 175, 199. 200258,259 .

lowd. Thomats 135.

l howney, John, jo6.

I rovle, Thomas, 121.

1)rayton, ('harles. $58,89$.

l)unn, Benjamin, 108.

Jwyer, Anthony, 137.

lyer, Eliphalet. 72 .

tamuel. t5 $^{\circ}+3$ 
Earle. Jolı1, I07.

IVilliam, $+1,+3$.

licling, Ruklple, 138 .

Ellery, William, 159, 165, 176, $185,192,217,219,2+2$.

Ellott, Harmard, 8s.

lienjamin, Sy.

"Iincleavor," 116, 119.

lingland, 181, 26.5.

lislick, lsaac, explesit of, 57 .

Estimates ordered of cust of cialdeden, (hrintopluer, 72.73. naty, 74 .

Evans, lavid. $12 \mathrm{I}$.

liveleigh. Nicholas, ss.

lixamination of fohn Cirannis before committee of ('ongress. 10 fo.

Eyres, Nicholis, Rev, s.

"Falcon," Ita.

Falmouth, 1RI, ISG, 200,

lanning, John, so, Iot. Juslutia, for).

latiler, R., 26 ;

fierguson, Mr., sig.

Ficles l'oint, I71, 172, I $9 \mathrm{~m}$. 207.

fight with the "Glasurow," 120.

lirst naral fight of the Revolution. 6.t. (6).

liwher's lolimil, 135.

Fiske, John, ifte.

litzpatrick, lieutenant, 124.

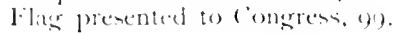

lecet, American, nimes of venrels in, s.?

sails for Xew lowidenee, (1) (x)

blestiuled in Narragamets liay, $r(x)$.

part of set to sea, 17 t).

final disperstion of shiph. $17 \%$.

1.leet, liritish, arrives in vewpowt. Itos.

"1.1y," $10 \%, 117,135,172$.

liender, Thombs, 137.

ford, lientimin, 139.

forellam, Kichart, os.

fortat line llith erected, pl.

is lint folonson, an.

fort Montague captured II 114.

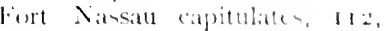
II $1,115$.

Foster, II illiatn L., 230 .

lingler, stephen, lot.

Fench 11:ar, 129.

livisbie. Mbel, Jos.

$74,75,7,7,7,7,2, y)$ (12, 1)3, (9).

letter wo E. Ifopkins, a

(ialsty, lhomas, 1 ;

"(iambiat," a bris, 20).

Gardner, Jolun, 14, 17.

sivage, $t)$.

"Cialspee," 32, 60, 172.

(ierorgia, 72, 73, 103, 154. 105.

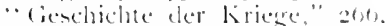

"Cilanget11," 120, 121, 122, I24, $120,129,130,1,32,13,3$, I3t. 1+1, 150, Itit, I-th.

liold Island, ou,

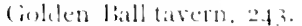

(iollemith, Ephraim, as.

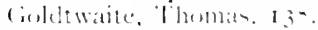

(iondrich, Vamenat kes.. ato.

Gimer, (herintian, 121.137.

Goulel, Mrse ledericts 1. 21.

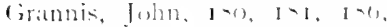
I $-1,101,1(12,105,100$ $202,204,21 ; .221$

Graves, Mathew, Ke\%, do.

fireen llowntains. 1ti.

lirecumoul. Juhn, 2-, 2ha

Ginnell. Milliam. 109, 207.

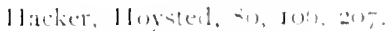
law i, (111, 107.

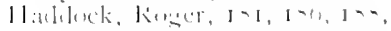
$112,117,244,205,220$.

11:difia, 203 .

11.11. 1ime- 139.

john, 139.

l'asker, Iow.

11:1lulas, Rinlent, 13?

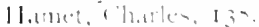

"Homplen," 1el. Her. 
Itancock, John, 125, 327, 133, Ilopkins, Esek, arrives on the 152216.231 .

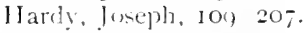

llarkeston, lsaac, at.

llarman, John, 139.

llarrison, Joseph. 107.

11 art, l'homas, 265, 266, 268.

llatteras, rox.

lawes, lienjamin colonel, 209.

"11awk," I20, 125, 162.

I lazard, (aptain, 122.

releved of command after court martiat 133.

1] eade, I homas J.. 260

lletne, kouse I. 219.

Hewes, Joseph, 75, $87,92,47$. 150

llinman, Elisha, 109, 119

lloadley, llon. (harles I. 32.

Holbrook, Albert, 3.

lloneyman, Iames, Rev, I g.

Hooper, IIilliam 105.

"llophins." It 3.

llopkins, Abigail, 247.

llopkins, Amey 247.

Itopkins, 'atherine, 34 .

llopkins, christepher, 30.

llopkins, 1lesire, 247, 248.

llopkins, Esek, Jirth of, 7 .

sails for sarinam, 7 .

marriatse of,

propounded a freeman, 9 .

takes outh of fidelity, $x$.

of selosel commuttee, 8 .

captures a snow, II.

at vew l'rovilence, 11 .

purchases a farm, 12.

shog leejer, 12.

takes Edward Abbey ap-

jrentice. 13.

directur of lottery, 13.

enters politics, Is.

elected to iremeral asecmbly,

15. $25.27,237$.

inuter an open letter, 75.

attackin fieorse laylor. 20. signs circulat letter agatinst

llewry llatrl, 24.

resigns inflece, 26.

coast of Africal 26.

reported from - urinam, 27. reported at -urinam, 27 .

has portrait painted, 25 .

deputy from forth Providence, 30 .

a committee to build fox 1 lill fort. $41,43$.

appointed lirigadier fieneral. $4 t$

establishes military headquarters, 45 .

direted to negotiate for raising blockade, fo.

letter to Vemport. \$9. 51.

to apprehend fieorge kimme. $=2$.

takes puscension of estattes in >ewport. 5t)

authorized to appoint a setretary 59.

of committee of inspection, 60.

selected as commander of the Nayy, 77.

an "experienced and renerable sea captain." 77.

notified of his appointment in the nary, $7 \%$.

receives letter from his brother stephen, 7 .

receives notice of his appointment in the naty, 79 . confirmed as 1 immander of >ary, bo.

rank in Naty (o) be same as Mathington in Army, so. sails for l'lilatelphia, i.

orders from taral fommiltee, $84,94$.

letter from christopher Ciatsclen, as, ge.

devines at signal 93

homsts first Anerican flatg on a war vessel, o)

assumes command of fleet, 9 .

letter to Nival committee, soo. 


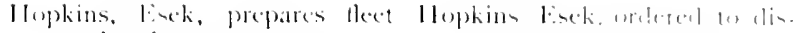
signals. $10 x$.

insules sailing orelers to (atplains. 100.

arriven at Mbaceo, 113.

cajtures Xassall, 113.

intues manifinto to people

(1) Xisutul. 114.

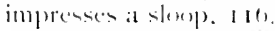

takes prisenters from 入itsatu,

117.

satils from liahathas, Its.

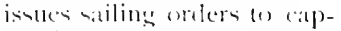

lains, IIs.

captures liriting sehooner,

" Ilawk." I20

apturen lorig, "loblum,"120.

allackis II. Ii. .1. -hip)

" 0 , langom," 120.

disapprotes une of liefuor.

$12 \div$

arrives at New londem, 125.

receives congratulations of

(imgress. 120.

subject of poetic eflusion. 127

criticised for fisht with " Rilasenw," 120

divpose of captured steres. $1 ; 3$

peronal appearance teseribeel. 134.

arrives in l'porielenee, 1.5. sectlres men from the arris. 135.

returia men from the army. $1 ; 0$.

orlere "loria," and "i ilfurt." (1) 42'al, 1 is.

maken ebarges atgainst anmemittedebaik shije, It melered to libilatelphiat, $1=2$

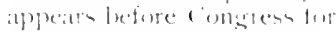
trial. 154

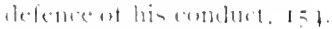

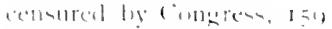

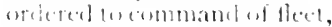
Itis.

receisen leder from John l'atul Jimen. I01.

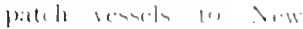
formalland. 112

anthorized te pundare at vesed 10,2.

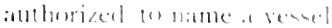
the "llokins." 1t?

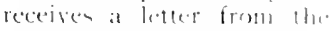
larine lommitter. Ita.

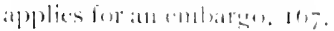

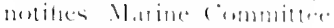
of atrivat of Prition Blece. 1(i).

makes attempl on the " loidmonel." $1-1$.

devribes altemple on the

" l diamonel." 173

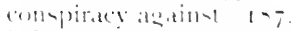

informe il illiam liflery uf conspiraly 112.

supendealfinm the enmmand at the >ats? $2+3.3$.

learns that hin whe lack in privenet al war. 2us.

receives confereion of three (anspiratery. 201.

orelers arrent and endurt martial of Keforr] Varvin. 2w-

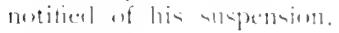
216 .

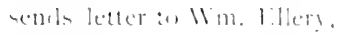
217.

institutes strit for libel. 22ul.

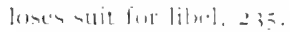

recelected lo cienerid at s(2111)ly, 237.

electerl he rinmeil of 11 ar. 23 .

ajprobled to examince tham

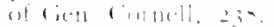

nominates fomen Vommine fur cintinentald angeren. 241.

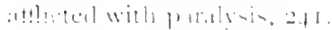

visith lohn Vilame - 13

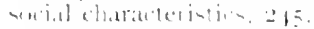

leath ame burial al. 21=

prositen for his chialen by will, $2+7$. 
Hopkins, Esek, name of chil-1 Jones, Robertson, 200.

dren, 247 .

statue erected. 249.

llopkins, Esek, son of Commodore Ilopkins, 203, 20.4.

Hopkins, Ileart, $2+7,245$.

Jopkins, John, iapt. 6, 34.

Hopkins, John Burroughs, 34. $80,83,120121,166,207$. $200,241,247$.

Hopkins l'ark, 249 .

Hopkins, kobert, 267.

Hopkins, Kufus, $1+7$.

IJopkins, Samuel, (apt., 6.

Hopkins, Samuel, 247.

Ilopkins, samuel, Ker., 254.

llopkins, titephen, Gov., It. I $5,17,23,3^{6}, 72,75,77$, $79,87,92,97,1+7,149$. $239,2+7$.

Ilopkins, Susannah, 241,247 , 2.4 .

Jopkins, Thomas, birth of, 2 .

Ilopkins, William, exploit of, 5.

Ilopkins, Milliam, 30, 34, IO9.

Jopkins, IV., Capt., I62.

"Ilornet," 91, 92, 106, 117, 177.

Ilorry, l'eter, os.

Ilouse, (ieorge, IOT.

Ilowe, l yringham, 122.

Jowlands Ferry, 119.

Juger, lirancis, 88.

IJuger, Isaac, sf.

Iluntington, samuel, 82.

IJuts, James, 107.

lyrne, Edmond, se.

Insubordination in the fleet. 185.

Jay, fohn, I66.

lenckes, kufus, 107.

Jennings, ( apt., I33.

Jentes, l'hilip, 10\%.

Jolnoson, J'elegr, Iot.

Johnways, Joseph, ato

Jones, fothin l'aul, -0, y, I 22 $133,136,150,161$.
Jons, Abel, 133.

Josiah, James, sos.

Juan Fernandez Island of, I12.

Kaine, Patrick, 12 I.

"Katy," slorp, 63, S1, 53.

Kean, Tho. .l. I65.

Kennedy, (ieorge, 12I.

Kerr, John, sos.

King, John, 13s.

King Ihilip's IVar, 3.

Kingstown, 167.

Knox, llenry, (ieneral, 265

knox, llenry, describes llopkins, 13.4 .

Jamb. William, 108.

Iangdon, Mr., it

"I ark," 203.

íaughton, sign painter, 28 .

1.aurens. Ilenry, 22 I, 222.

leary, Jennis, Ios.

lee, Charles, teneral, 79, 80.

I.ee, Richard 1lenry, 75, 101, 165.

letter of Congratulation to Jopkins, from congress, 120 .

letter from Esek IJopkins to IIilliam Ellery, 192, 217.

Letter from John ['atul ] ones, to Esck llopkins. Itor: to Josepli llewes, quoted. $I=0$.

Letter from Narine Committee to Ilopkins, 163 .

"I iherty, "slowp destroyed, 31.

I. ist of ifficers for nasy, so.

List of stores citptured, is

List of kibled and wounded in "Cilangow" fight, 12 I

I. ittle 1 omptom, $2(x)$.

bittle folmn. 13?.

I.ittleworth. A.

I our bowk of the ". Mlfred," I 23.

lomion, 111, 142, 265, 266, 267.

long I-land, I 20.

1.othrop), liamabas, Iso, I86, 105, 107, 220, 231,234 . 
lowndes, Mr.. Bon.

l.owry. Nexander. 13\%.

1.yon, sam, 200 .

ljuch, Ihumas, Ir.. s.

Malar. Jacol, I 3 s.

Mlagee, Andrew, 135.

Nallune, Ciolftey, zu.

Maltbic, fonathan, 107.

Nan, licijamin, 13.

Mamning. Iames, Rer., 223. $225,24^{\circ}$.

Marchant, llenry, 211 .

Norgeson, John, 109, 100.

Narion, Francis, on.

Marvin, Richard, 181, I, 2,143, $184,150,159,197,205$. $200,207,213,214,215$. $220,221,222,223,231$. 234 .

Maryland, 72 .

Mason. William, st.

Mawney, John, ().

Maxey, Jonathan, $2+r$.

Mceloud, Kenneth, 150 .

Mclonald, Idam. Sn.

Mclonald, James, st.

Mclougall, John, 108.

$\mathrm{Mcl}$ lougall - so.

Mclarling, kobert, I 35 .

Mintosh, Mlexander, os.

Mckenny, (ieorge, 13\%.

Mclienzie, Mex. Ios.

MeNeal, Iohn, yoy.

Mcciorley, lames, 135.

Mcsparran, James, Rev, 19.

Mclee. Mathew. 135.

AclWhoton, William, toos.

Medway, 207.

"Mellish," IIo.

Members of (ommittee to build ships in khode lsland. I45; abanden the work. $1+9$.

Memorial to continental congress, 60).

Mendon, 1so, 207. 205.

Middleborough, 186, 197, 220.

Middleton, Arthur, I65.

Middletown, 45, 208.
"Milford," 177.

Nills. Kolent, 1,34.

Milton, 7 .

"Minersa," privitecer, " 2

Noran, Milliam, 10m.

Morts, Kolett, 115.

Mette, ('barles, as. lsate. as.

Moultric, Milliam, -

Muray's lompantial Hintong of the .merican Mar, at.

Mlumford, l'aul, 5u.

Names of ships lowile in Khole lsland, 147.

Narrative and Critical llintery of America, $24,2,207$

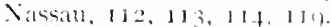

Naral ('ommitter apposinted, - th 75 .

Xaral committee, whers ot, 4. (3)

Naval tight, first, of the ketolu(ii) $11, t(t)$.

Naty, American, origin of eme.

Nary, debate in fongrem wer. 72.

Nary, proposed. 74. 75

Nederlandseh Mercurius, 267

Neptune, 12\%.

Sewbern, 77.

New lionel stecet, 267.

New Castle, 13.

New (astle upon livne, 26-

Newfoumlland, 162, 103, 14,

New Ilamphire, $1+3$.

New lanton, 11, 125. 126. $127,131,133,1,4,135$. 131). $1+1,224$.

Newman, Mr. 22.

Newport, 45, 6.5, 79, $111,120$. $122,132,13 ;, 135,131)$ $160,160,170,171,100$. $20 \pi, 20(), 223,22(1,227$, 221). $232,237,2=4$

New l'rovidence, 104, 105. I 10. $111,113,114,11,154$.

Newsof Ilopkins exploit wased published, 125. 
New York, 127, 135. 136, 143, Potter. Stephen, 223, 230.

$155,1=6,197$.

Nicholas. (apt. I 13.115.

Nightingrale Joseph, $1 f^{0}$.

Nightinirale. Camuel J $\mathrm{r} . .+\mathrm{I}+43$

North (arolina. 77.95 .156$. $16+, 105$.

North J'rovidence, incorporated. 27.

Nova licotia. 17\%.

Olney, Joseph. 9. E0, 100. 223

Orders to Comnander-in-chief, st

to Captain Sitone. 91 .

Origin of American Nay, 6o.

Origin of names of vessels, s.

Osborn. William, I37.

Otway, Lieutenant. 203.

Owen. Captain, 26.

() yster liay, f.

Page, Ambrose. ('apt. 28, 3r), 41. 43. 223226.

Paine, lobert i reat, 72 Thomas. Is3

I'arker, sir l'eter, 190.

Patience I land. 172,258 .

l'atrick, lohn. 135.

learce. lienoni 13.

l'eck, George, 110.

Ienobseot, 17 .

lerry, $26 \mathrm{I}$.

l'etition to (ongress against Hopkins, $157,109,1013$.

Philadelphia. (10, 77. (75, 104. 126, $130,133,130,137$. $152,153,154,159,162$. 10I. 195. 202. 204. 224 . 225

Pierce, 11 illiam. Iot).

l'inkney, ('harles ('., ss, so lhomán.

I'itcher, Innathan, o0, 107.207. l'lymouth, $20^{4}$.

l'ollard, R. 267.

"l'olly." a sloop. 57.

I'ony, Jacoh. I39.

I'ope, -6 .

lotter, kichard. Ios.
IVilliam 37 .

l'owler scarcity of, 104.

sent allay. 117.

l'owell. Culonel. 8ty.

l'owel, Iames, 107

Power, Nicholas, 20, +1

l'reble. Admiral 267.

Privateers interfere with the manning of the tleet, $1+5$

"l'rovidence," - 1, 109, 122,133. $135,136,147,161,169$. $171172,175,175179$. 195, 200, 203. 207. 205, 220.

l'rovidence (iazette, $47,240$.

l'utnam, Israel, zot).

guthec, 110.

1) ueen Anne, is 2.

kandall. stephen, 0.

Randolph, l'eyton. -2

Rathbun, John. Ios.

kavencroft. Jomeph, I 3 h.

Rawson. Flizalyth. 207

kead, Joseph, colonel, ac-

keding, lewis. I39.

Reed, John, I-1, I=6, Ios, I =9. 191. 192. 197, 204. 205. 206,222 253. 254.

keiney, Chrimtopher. 1 so.

lievolution, first naval fient, 60.

keynolds. II illiam. Ios

Rhode lstand College, 10. 24t.

kichards, l'eter. Ion.

kicler, sidney \&. 230

koatch, Iohni, 13

Roberts, loavirl. Iot.

Uwen, as

kobinson. kobert, Iot,

kutson, T.. 26.

liogers, Iorg.

kogers, 1 oomles, 11 I. 112.

Rome, (ieorge. 53 .

"line." a hrir. 27.

"licke," frigate. 40. 47.6.4.

kound kobin, petition for pay. 137.

kules of the lox loint battery.t! 
Russell, James, 139. Joceph 1 f6.

Rutledge. Filward, I60. folin, 72 .

"Sally." 3.

Saltomutall, Indley. So, 82, 83, (3). 15. 150,152, 153.

Sintiature, 1eng.

Satumlers Robert 107. linger. 8s

Saytes Ilemorial Ilall. 268.

"Scirborough," 132.

"scorpion." ro.t.

Seott, Willitm. 8s.

Scranton, inimiel. 106.

Scabury, lienjamin. $80,107$.

Seaconnet river. 208, 200.

Seamans, Hatim, 220.

"- Dea Nympli" 162 .

Selkirk, Alexander, II 2.

Sellers, James. 180, $181,186$. $135,197,220,231.233$. 234.

Sessions, l)arius, 37.

Seymour, (harles finclair, 12I, 124.

Shaw, Samuel, I80, 186, I87. 185, 102, 197, 204. 205. $200,220,221,222,223$, 224.

shepard, $\therefore 260$

Sherburn, colonel, 208. 200.

sluereman, Joseph rog.

ships to le built in khoule lsland, $1+5$.

Sickness in the lleet. I34.

simall pox in the fleet, Io5.

Snatl. William, izs.

smith, John, 13. simon. 41,43 .

South (arolina, 72, 95, 117. 156 , I 65.

spain. ifo.

spencer, llajor General, 203.

Spooner, IIalter, IOT.

Siprout, libenezer, 220.

Stanslury, - So.

Staples, Judge, 163. stillman, (iecorgere, 1, 1, Int, Ins, (1)7, $220,231,234$.

trirlin Juhn, 137.

- I a arence ciulf of, 102.

sone. Ililliam, st. an.

sullixan, folun. atc.

sullivan, - $2 \mathrm{~m}$.

sweeney. Richard. 139.

hivord Jolen 105.

I:aunton 180.

litylor, (ieorse, shomblanter, (y. it.

Taylor. lieorge, atecount of, 22.

lavter, lob. (iapt. 204.

lest party referred to, 32.

lemant, Rer Mr, ald.

'Tentinumy in libel suit, 223.

Thaster, Vham 11., 207, 213.

Thirel. Michacl 13 \%.

Ifomal, fames, 107.

Thompand Funice 207 .

llilliam, - (), I 3 \%.

Thorp Mielatel. 13 's.

fillimghas, lonicl. 1f6. 205. 216.223 .221 .

Tillinghast, Nicholis, 13.

Timothy, Mr.. so

lower Ilill. fo

lomy, Michatel $10 \%$.

Trowilen, James. 121.

Truman, fohn, 191, 186, 183. $10 ;, 220,231,233$.

lrumbull, Jonathan, $82,119$. $133150,163$.

Turpin, William, (1.

Tyler, Nithan, folonel, 205.209. samuel, 100

Cplike, John, $+1,+3$.

(j)ton, 200 .

Van Tromp, $13+$.

Vaughan, loniel. -o.

lhomas, 107.

Varrel, firancis, 107.

Verses commemotative of [lop)kins exploit, 127.

lesey, 11\%, 175 
"Viper," 11. 1. 11. Sloop. 57. I Welch, John, 108.

Virginia, - $72,95,1+2,154$. I 56,165

West lindies, $1 f^{f}, 229$.

West, James, $153,154$.

Robert, 2.

"Wainscot," a brig, I 6 .

William, Colonel, 4t. 70 .

Wallace, James. 40, 45,65.6.8, Whipple, Abraham. 33. 40,63. I 20, 122, 139 .

Vallace, James, letter to town of Newport. 47 .

letter to ciov. coolie. 05.

letter to Abraham Whipple, 68.

Wanton, Jonas, 28.

Wanton, Jostph, (iov, 37.50.

Ward, llenry, tecy., 23, 24. 35. 39.44. 64, 68, 60, 81, 43, 120. $132,133,1=1,152,153$, $172,174,190,207,205$, 209, 2II, 212, 214 note to James 11 allace. 6,8 . demands a court martial, I 29.

ordered to l'hiladelphia, 52 .

IVard, Samue], 14, 23, 51, 159.

Warner, Elijah. I0s. Elisha. so.

"Warren," It7, 169, 171, 172. $175,177,175,179,101$, $182,185,106,187.1>9$, 102, 196, s97, I 39,109 , $200,204,205,200,200$. $213,214,218,210,228$, $231,132.233 .234 .235$, 257.

Warwick, 171, 172, 173.170.

Washington, (ieneral, 7\%, so, $104,135.153$.

"Mashington," a vessel 63.

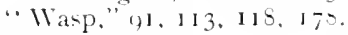

Mayn. Joseph. I 38

Neaver. Thomas, 80 , 108. I 13. Villiam, I06.

White. 1 yons. 88

Wickendén, William, 4 .

Wicks, Themas, 37.

Wild, Edward, Irr. 20. Mary I.. 29.

Wilkesm, James, 137.

Wilkinson, l'lain, 4 . Ruth, 4 . camuel, $t$.

Williams, Roger, 2.

Williamson, Frank A., I Jo.

Wilson. James lloard, I21. lieuterant, 124.

Winsor, $266,267$.

Wooster, (ieneral, 155.16I.

Wrixon, Mr, IoI.

Wyoming, $\mathrm{I}+3$.

Vorke, John. Io6.

loung, John, so6, 139.

Webb. James, Captain, 20r.

Weeks, 200.

Zobly, Ker. Hr, 72. 73. 


\section{THE COLONIAL TAVERN:}

A Glimpse of New England Town Life in the Seventeenth and Eighteenth Century.

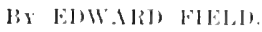

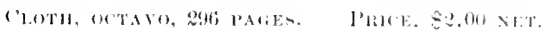

A century or more ago the tavern was an inportant institution in the life of New England and the center of town activities. Aromul these old taverus with their cavernoms firephees and well-storked buffet the anthor has gromped many fuaint tharacters of real life in scenes of actual ocentrence. Old diaries, conrt reeords, letters, town and amuty records and histories have smplied the material for these pictures of eolonial life.

The tavern stories of Indian attack, Puritan persecution and romantic love reall many interesting events in New England history, while a chalter on the tavern in the Revolution gives an aeconnt of the important part played hy the tavern in the strumarta for independence.

"In the handsomely printed volume under review Mr. Fiesd has presented a gossing. entertaining sketch of this servant of thes secial want of early New England."-The lation. 


\title{
THE MAGAZINE
}

....OF....

\section{NEW ENGLAND HISTORY. FOR 1891, 1892, 1893.}

Having purchased the few remaining complete sets of the Mingaine of New England History, originally published at sloo, we offer the three volumes in parts as issued for \$2 50 net per set or homd in one volume, roth, for \$3.50 net.

These volumes contain nearly eight humdred pares of information relating to New England local, church and family history, including records, genealogies, journals, letters and many. interesting notes and queries.

\section{WHAT CHEER}

-() $1:-$

\section{ROGER WILLIAMS IN BANISHMENT.}

\author{
A PUEM BY MUR DTRFRE.
}

Revised and edited by THosis hrofer.

Cloth, Leather Labed, 12 mo., 225 pages. I'RI'E $\$ 1.25$ Ner 


\title{
A Summer Visit of Three Rhode Islanders to the Massachusetts Bay in 1651.
}

\author{
liY IIENRY MEINIELE KING.
}

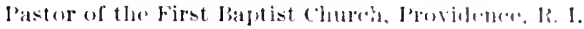

Cloth, 12mo., 115 pages. Price

Unifurn witle "Man Mres.,"

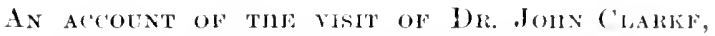

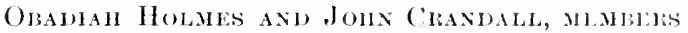
of The Baptest (Herch in Numport, Ri. I, To

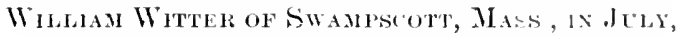

16is1 : ITS INNOCENT PURPOSE ANU ITS PAINFUL (UNSEQTENCES.

"Dr. King's pungent and ronclusive tosaty is a timely contribution. He alduces eompetent evdence renting the gratuitons insinnations of l'alirey and Dexter, who edaroged the Jihode Islanders ju question wath sinister polstical motives and exemated their alleged maltreatment on that srommel. Citations from original documents, with a liblicuraply, put the reader an posituon to verify the allewations of the anthor."-The: Hatreman.

Sent postpaid mpon receipt of the price ly the publishers. 


\title{
Revolutionary Defences in Rhode Island.
}

\author{
AN llistorical Acrotext of the Fortificatioss axd \\ BEACON ERECTEI DERTA: THE ABERICAN REVOLU- \\ THS, WITH NI-TEAR ROLLE OF THE COMPANIES STA-

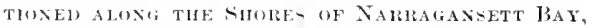

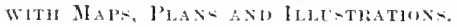

\section{IBY E]WAR FIELI).}

Past Plesident of the Ribde Island society of the sons of the American levolution.

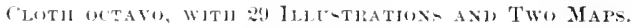

PHICE \& \$, NET.

This volume contains an account of the varions works of dofence erected in the state of Rhode Jsland during the Revolutionary War. showing where and under what cirrumstances ihey were built, and the names of the offeces and enlisted men located at many of them at farions periols of the war.

For nearly three years the british Army was lowated within the state and one of the notalle battles was foutht within its territory. The war may of this battle of Rhode Isiani, now preserved in the state archives, has beten especially reproduced for this work, and is shown in its entirety for the first time.

The work is profusely illustrated with plans and riews of these old earthworks, towether with illustrations of the styles of equipments and fac-similes of enlistment papers for the continental Army, A Map of the state of Ihode Island is inserted showing the location of each fort, heacon, and coast guard station described in the text.

Muster rolls and company lists containing the names of more than seven hunked offiers and enlisted men. many of which hare been hitherto inaccessible, are here presented. The records of Rhorle lstand sthliers in the War of the Revolution are scattered and in "omplete. and the names contained in this book will be of great assistance to those who desire to ascertain the serrice of Rhorle lsland Soldiers. or to establish their right to member. slip in the hereditary patritic societies, for the names have been carefully trancribed and reference is wiven in each case where the original muster or bay roll may be found.

sent pestpatid npon receipt of price by the publishers. 


\section{History of the State of Rhode Island and Providence Plantations, 1636-1790.}

\section{By SAMUEL GREENE ARNOLD.}

New Edition. 2 vols. Octavo. 574 and $600 \mathrm{pp}$. \$7.50, net.

Gosemor Arnolul's llistory of khoule latinel, based upun a careful stude of docments on the bumsh state l'aper oftices and in the Rlsede lstand state Arehores, supplemented by in-

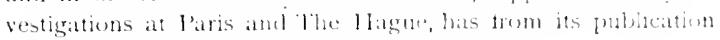
been the anthoritative hastong ot the state.

Genealogical sturlente will fund in there volumes the nomes of

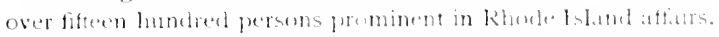
the wolk is of much more than heat interest, as the experiment of peligious liberty bere tried glwes to thr history an importance tar beyol the narow limits of the state.

"()ne of the best stote hutories ever written is S. C. Arnoll's Hlis-

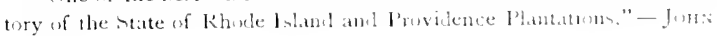
FISKE.

"The best history of Rhole Istant is that of Amoll." - Prow.

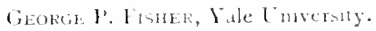

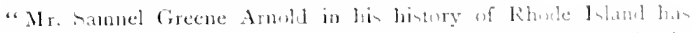

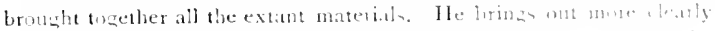

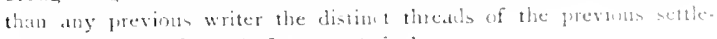

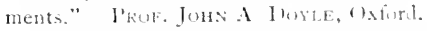

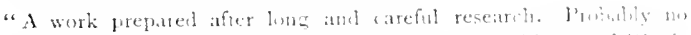

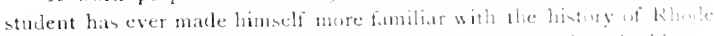

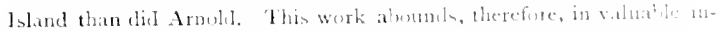

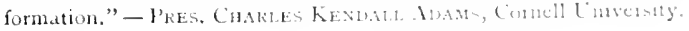




\title{
Tax Lists of the Town of Providence
}

During the Administration of Sir Edmund Andros and his Council,

\section{$1686-1689$.}

\author{
Compiled by EDWARD FIELD, A.B., \\ Member of the Rhode Istand Histrical Society, and one of the \\ Recort Commissioners of the City of Protitence.
}

Cloth. Octavo. 60 pp. $\$ 1.00$, net.

The "Tax Lists of the Town of Providence" is a compilation of original documents relating to taxation during the Administration of Sir Edmund Andros and his Council, I686-I689. It comprises copies of warrants issued by order of the Council for the assessment and collection of taxes, the tax lists or rate bills prepared pursuant to these warrants, the returns made by the townsmen of their ratable property, and the Tax Laws enacted by Andros and his Council. All of these, with the exception of the laws, are here printel for the first time.

Among the rate bills is the list of polls for 1588 , which con-

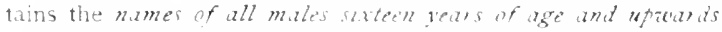
lieng w Prozudence on Alugust of that yen; practically a census of the town. For the genealogist and histurian this volume contains material of the greatest value on account of the great numb.. of names which these lists contain, besides showing the atmount of the tax assessment in each case.

The returus of ratable property form a study by themselves, for they tell in the quaint language of the colonists what they prosess, and therefore shed much light on the condition of the times. For a study of this episole in New England Colonial Hivory this work is invaluable.

The index of all names contained in the lists and text is a teature of this work.

The edition is limited to two hundred and fifty numbered copies.

Sent postpaid to any acluress on receipt of one dollar. 


\section{MARY DYER OF RHODE ISLAND,}

The Quaker Mample that was Haxged ox Boston

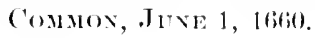

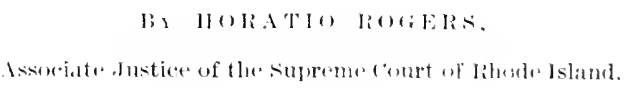

The anthor has gathered from many sourees the scattered facts relating to the eareer of Mary Dyer and woven them into a detaile. 1 narrative, so that the tracice story of her life is now for the first time alecuately fold. By adling a brief hut comprohensive sketch of the manner and sentiments of her times he has furnished a biekerome or framework for his subject which adds much to the in terest of the volume by enabling the reatide the better to muderstand the smrommlings of the characters he portrays. The important doements relating to her trial are printerl in the anpendix.

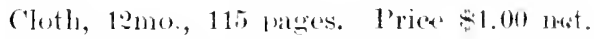

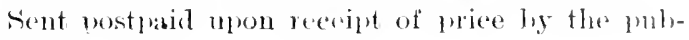
lishers. 


\title{
NEW ENGLAND WILD FLOWERS AND THEIR SEASONS.
}

\author{
BY W. WHTMAX HAJEY.

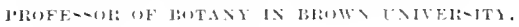

Cloth, 16imo. Uniform with "R. T. Wild Flowers." ii) cents wet.

From long wanderings atield the anthor has caught the charm of the varying moots of ome New England year and pictures them for the reater with smmpathetic touch.

The characteristics of the conspicuons and dominant flowers of the months are sketched in fromat lines, rendering illentification eacy.

The flowers of the White and (ireen Momntatiss -onr alpine flora - receive sebarate treatment, als (1) also the flowers of the sea-shore- om arant flora.

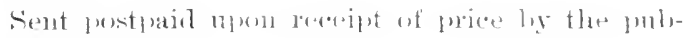
lishers. 


\section{THE EAST INDIA TRADE OF PROVIDENCE,}

From 1787 to 1807. BY GERTRUDE SELWYN KIMBALL.

By a careful study of log hooks and eommercial papers of the old shipping firms, the author is enabled to present an juteresting pieture of the East Iutia 'Trute of Providence in its palmy days.

Svo. 34 pages, mper, 50 conts net.

Sent postpairl on receipt of price. 


\title{
SAIMIUELL GOR'TON:
}

FIRST SETTLER OF WARWICK, R. I.

\section{A FORGOTTEN FOUNDER OF OUR LIBERTIES}

\author{
BY LEWIS G. JANES, M. A.
}

PRESIDENT OF TIE BIOUKLYN ETHICAL ASSOCIATION

Cloth, 12mo. Price \$1.00 net. Uniform with "Mary Dyer" and "Summer Visit."

A careful, conscientious and sympathetic study of one of the most mique figures in our colonial history, and of some of its most exciting episorles.

It is the first oy otematic attempt to give candid and judicial interpretation of Gorton's preenliar religions views, and is of expal interest to the thrologrian and historical student.

Sent postpaid nom receipt of pries by the lublishers. 


\title{
THE HOMERIC PALACE.
}

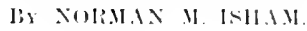

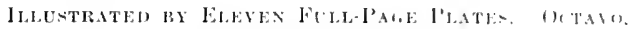
(IOTH. S1.00 МET.
\end{abstract}

The Honeric Palace is an attempt, in an inexpensive and convenient form, to set the main lines of the royal dwelling of Homeric times before the reader of to-day.

The text eollects the main faces abont the dilfierent parts of the palace. The drawings show the plans of the great strongholis, Troy, Thirns, Ime, Mycense, and wather into one plate the varions types of rampart walls, into anotlere the gates and allproaches. Bird's-eye views show, in one plate, fonr stages or steps in the building of at palaces, in another a restoration. which is half phan, half section and elevation combinea, of thr palase ut liryos, a view whielh, so far as we know, has nerer lefore been published, much as that building has been drawn and restored.

All bovers of classieal myth or history will timit the work interesting. 'lo the student it will be a eonvenient text or reforence book, and to the teachere of Homer it will be invaluable. 


\section{EARLY \\ CONNECTICUT HOUSES.}

BY NORMA. II ISIIAM AXD ALBERT F. BROWX

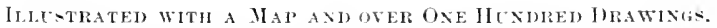

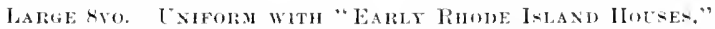

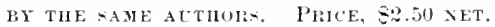

This book treats the early houses of Connecticut in the same way in which its predecessor treated the dwellings of Rhode Island.

The same accuracy of measmement and drawing and the same tareful description of the early work characterize the new volume.

The work describes a large number of honses in Hartford and its nejghborhood, in New Lomdon, and in New Haven and the towns confederated with it.

Mnch new information will be fom in the chapter on Construction, and the relation with English work is considered in the light of further stmdy of txamples in the old country.

Edition limited. 


